UNIVERSIDADE DE SÃO PAULO

FACULDADE DE ECONOMIA, ADMINISTRAÇÃO E CONTABILIDADE DEPARTAMENTO DE ADMINISTRAÇÃO PROGRAMA DE PÓS-GRADUAÇÃO EM ADMINISTRAÇÃO

CONTRATOS DE ETANOL CARBURANTE E A RACIONALIDADE ECONÔMICA DA RELAÇÃO ENTRE USINAS E DISTRIBUIDORAS DE COMBUSTÍVEIS NO BRASIL

Fabio Dolnikoff

Orientadora: Prof ${ }^{a}$. Dr ${ }^{\text {a }}$ Maria Sylvia Macchione Saes

SÃO PAULO

2008 
$\operatorname{Prof}^{\mathrm{a}} \operatorname{Dr}^{\mathrm{a}}$ Suely Vilela

Reitora da Universidade de São Paulo

Prof. Dr. Carlos Roberto Azzoni

Diretor da Faculdade de Economia, Administração e Contabilidade

Prof. Dr. Isak Kruglianskas

Chefe do Departamento de Administração

Prof. Dr. Lindolfo Galvão de Albuquerque

Coordenador do Programa de Pós-Graduação em Administração 


\title{
FABIO DOLNIKOFF
}

CONTRATOS DE ETANOL CARBURANTE E A RACIONALIDADE ECONÔMICA DA RELAÇÃO ENTRE USINAS E DISTRIBUIDORAS DE COMBUSTÍVEIS NO BRASIL

\begin{abstract}
Dissertação apresentada ao Departamento de Administração da Faculdade de Economia, Administração e Contabilidade da Universidade de São Paulo como requisito para a obtenção do título de Mestre em Administração.
\end{abstract}

Orientadora: Prof ${ }^{a}$. Dr ${ }^{\mathrm{a}}$. Maria Sylvia Macchione Saes

SÃO PAULO 


\section{FICHA CATALOGRÁFICA}

Elaborada pela Seção de Processamento Técnico do SBD/FEA/USP

\section{Dolnikoff, Fabio}

Contratos de etanol carburante e a racionalidade econômica da relação entre usinas e distribuidoras de combustíveis no Brasil / Fabio Dolnikoff. -- São Paulo, 2008.

$162 \mathrm{p}$.

Dissertação (Mestrado) - Universidade de São Paulo, 2008

Bibliografia.

1. Álcool como combustível 2. Contratos 3. Governança corporativa I. Universidade de São Paulo. Faculdade de Economia, Administração e Contabilidade II. Título.

CDD - 338.17361 
À minha esposa, Daniela Madeira. 


\section{AGRADECIMENTOS}

Agradeço à minha esposa Daniela pelo amor e incentivo, que me ajudaram tanto a ultrapassar cada etapa deste desafio chamado mestrado.

Aos meus pais, pelo amor e torcida inabalável.

Ao CNPQ, pela bolsa de estudos.

Aos professores Isak Kruglianskas e Decio Zylbersztajn, pelo grande apoio neste período, assim como a todos os professores da FEA por toda atenção e disponibilidade.

Aos amigos e pós-graduandos Antonio Carlos L. Nogueira, Carlos Xavier e Roberto Pedroso Jr., pela enorme contribuição ao desenvolvimento de meu projeto de pesquisa e dissertação.

Aos integrantes do Pensa e aos meus companheiros de mestrado, por uma convivência tão positiva e incentivadora.

Aos executivos entrevistados neste trabalho, pela disponibilidade em participar desta pesquisa.

À colaboração especial dos meus amigos José Luis Sterman e Leonardo Massud.

E, por fim, agradeço a D`us pelo privilégio de ter sido orientado pela Professora Sylvia Saes. 


\section{RESUMO}

Este trabalho teve como objetivo propor um modelo econômico que refletisse a racionalidade da decisão de usinas e distribuidoras de combustíveis ao optarem por uma estrutura de governança para coordenar seu relacionamento, no tocante à comercialização de etanol. Para perseguir este objetivo, adotou-se como aporte teórico a Nova Economia Institucional e optou-se pela metodologia de Grounded Theory. O método de coleta, entrevistas em profundidade semi-estruturadas, e o método de análise, a Grounded Theory, foram estruturados sobre o modelo de análise contratual de Bogetoft e Olesen (2004), modelo que analisa a adoção de contratos alinhado à Nova Economia Institucional. Vinte e uma entrevistas foram conduzidas com agentes representando usinas, distribuidoras e organizações de classe. Observou-se que, em 2007 e 2008, a principal estrutura de governança utilizada na relação entre usinas e distribuidoras de combustíveis era um mix de contratos e mercado spot, tanto para o etanol hidratado, como para o anidro. Analisando o conteúdo das entrevistas, entendeu-se que as usinas optam por contratos devido a uma necessidade de garantia de fluxo de caixa, e as distribuidoras fazem esta opção para estabelecer uma programação logística que minimize seus custos. Em ambos os casos, tanto para usinas, como para distribuidoras, é necessário estabelecer com antecedência o local e o volume de produtos que os agentes pretendem comercializar, o que evidenciou a presença de especificidade locacional e temporal dos ativos nesta transação, e, consequentemente, a presença de custos de transação neste relacionamento que, de acordo com Nova Economia Institucional, explica a opção dos agentes pela estrutura de governança vigente. 


\begin{abstract}
This work proposes an economic model which reflects the reasoning behind the decision of plants and fuel distributors to choose a governance structure to coordinate their relationships, with regard to the commercialization of ethanol. It uses as its bases the theoretical framework of the New Institutional Economics (NIE) and the research methodology of grounded theory. The collection method, in-depth semi-structured interviewing and the analysis method of grounded theory were structured on the model for contract analysis purposed by Bogetoft and Olesen (2004), a model which analyzes the adoption of contracts in alignment with the NIE. Twenty-one interviews were conducted with agents representing plants, distributing firms and class organizations. It was observed that the main governance structure used in the relationship between plants and fuel distributors in 2007 and 2008 was a mix of contracts and spot markets, both for hydrated and anhydrous ethanol. The analysis of the content of the interviews led to the understanding that plants opt for these contracts due to the need to ensure cash flow, whereas distributors make this choice in order to develop a logistic plan that minimizes costs. The fact that both plants and distributors need to predetermine both the site and the volume of the products the agents intend to trade evidenced the presence of location and time specificity of the assets in this transaction. Therefore, transaction costs are present in this relationship, which, according to the NIE, explains the agents'option for the governance structure in force.
\end{abstract}




\section{SUMÁRIO}

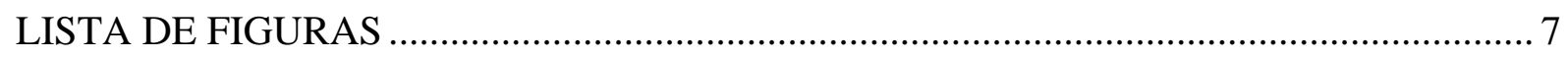

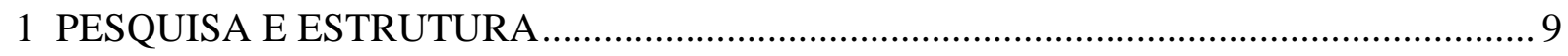

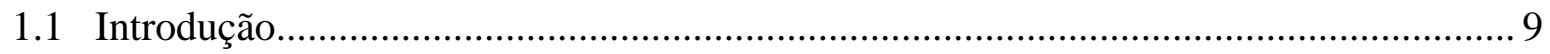

1.2 Observação do fenômeno e formulação do problema de pesquisa .............................. 10

1.2.1 O problema de pesquisa e seu objetivo implícito................................................. 11

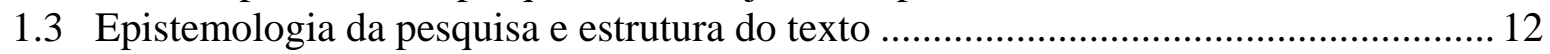

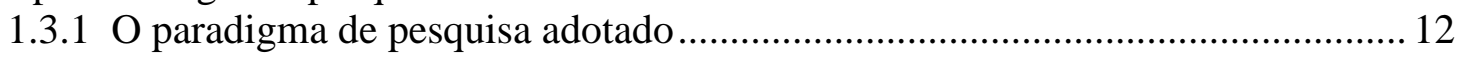

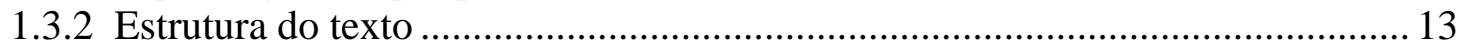

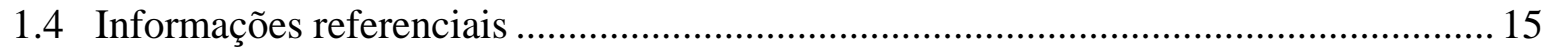

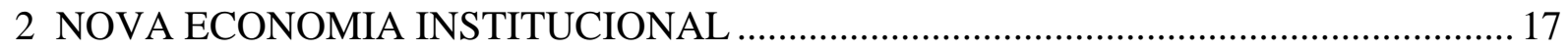

2.1 Nova Economia Institucional e os custos de transação............................................... 17

2.2 Direitos de propriedade e custos de transação .............................................................. 19

2.2.1 Economia dos Custos de Transação (ECT): abordagem da governança............. 20

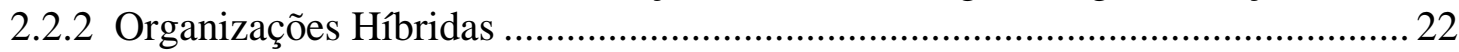

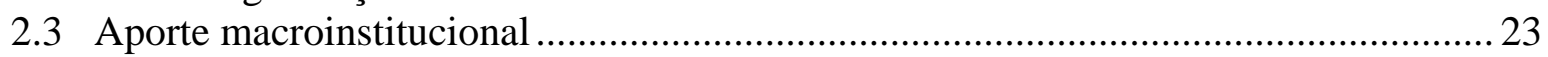

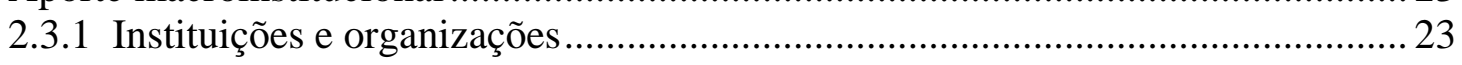

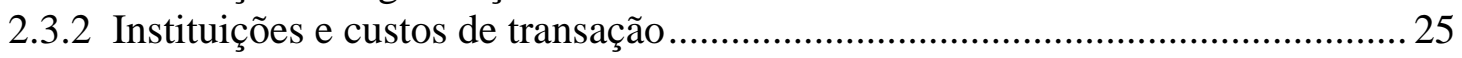

2.3.3 Instituições e desempenho econômico ................................................................ 26

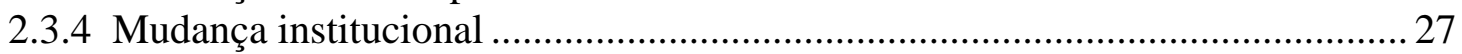

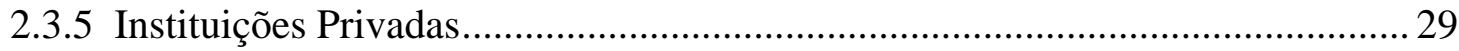

3 TEORIA DOS CONTRATOS: UMA ABORDAGEM HOLÍSTICA .................................. 33

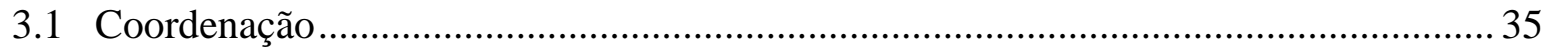

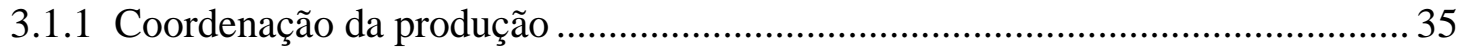

3.1.1.1 Coordenação do processo produtivo ...................................................... 35

3.1.1.2 Coordenação do comportamento de mercado na cadeia ...................... 36

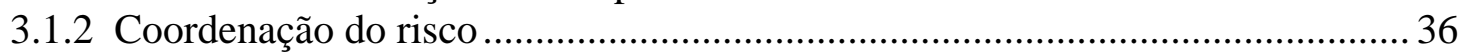

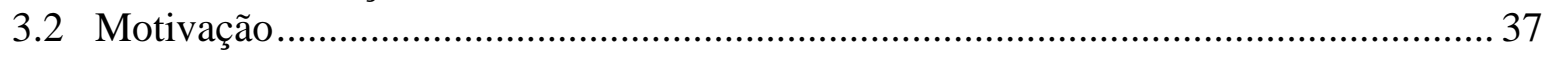

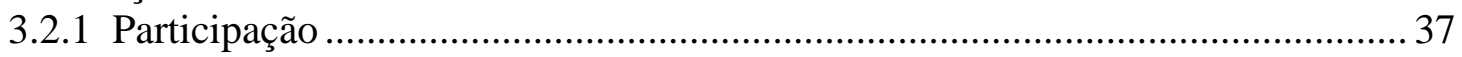

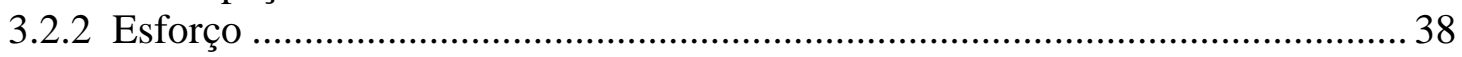

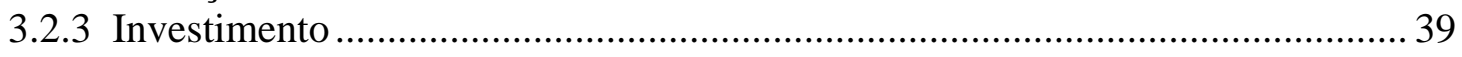

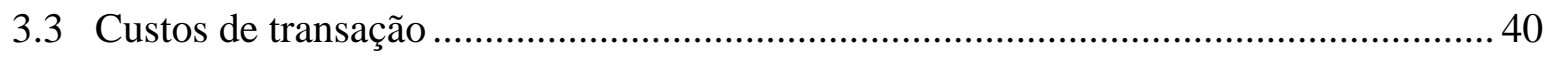

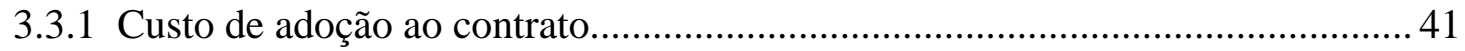

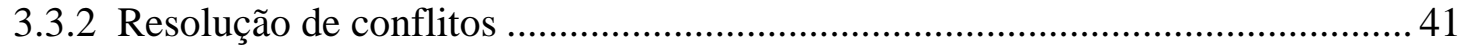

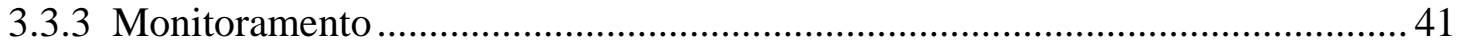

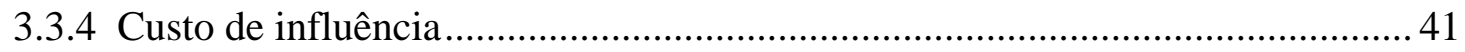

4 A INDÚSTRIA DO ÁLCOOL ETÍLICO …................................................................ 43

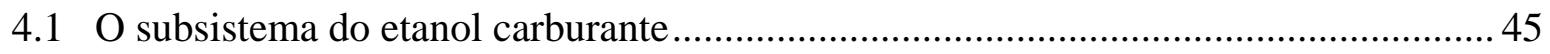

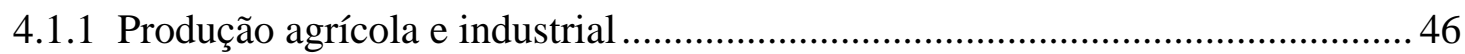

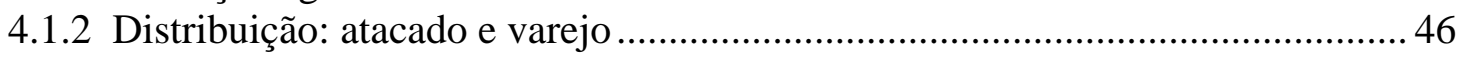

4.1.3 Exportação...................................................................................................... 48

4.2 As usinas e a estruturação da oferta ....................................................................... 50

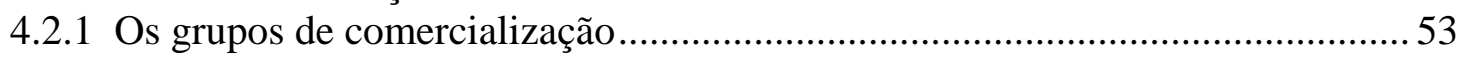

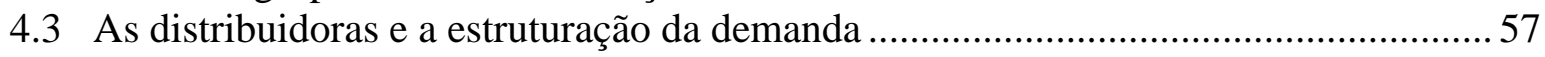

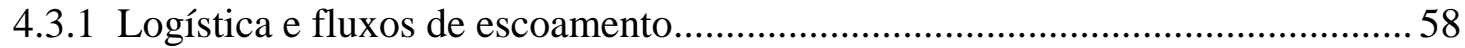




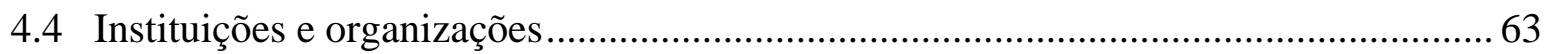

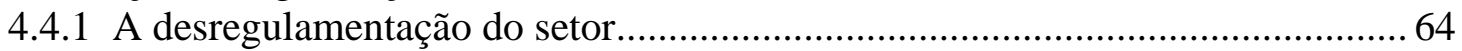

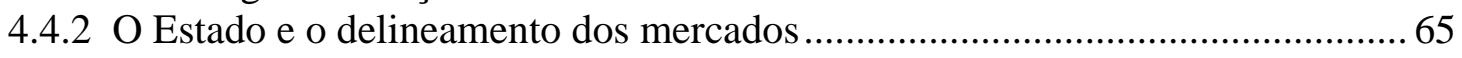

4.4.3 O Estado e a competitividade entre os agentes econômicos ............................. 66

5 HIPÓTESE E OBJETIVOS DA PESQUISA …………………………………………........69

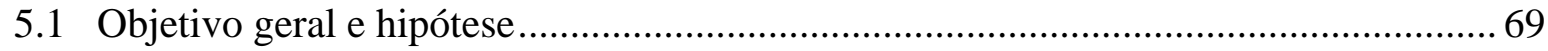

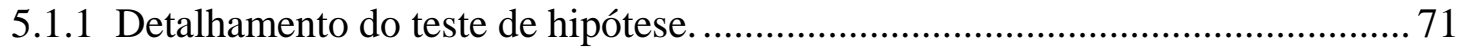

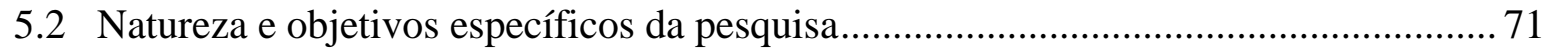

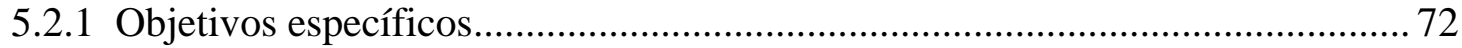

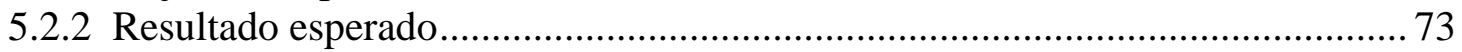

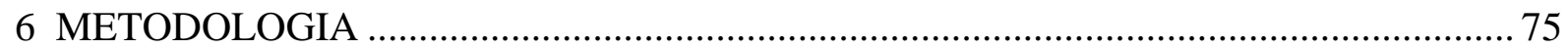

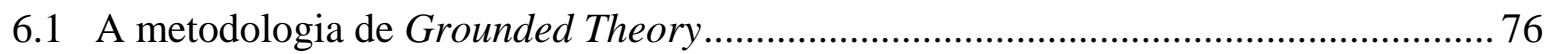

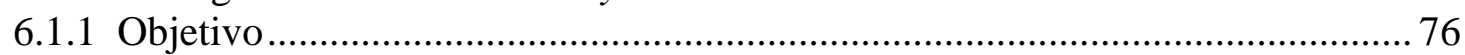

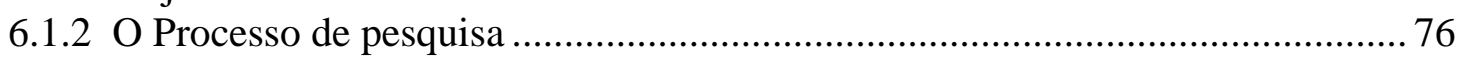

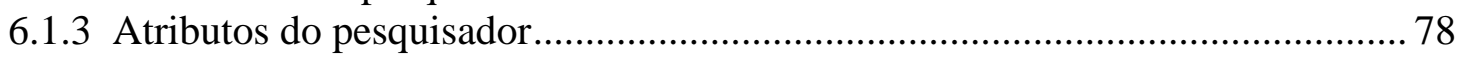

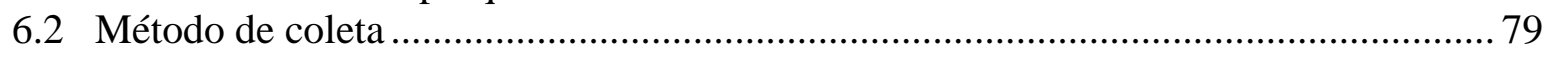

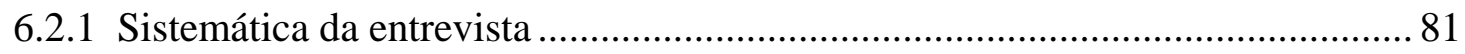

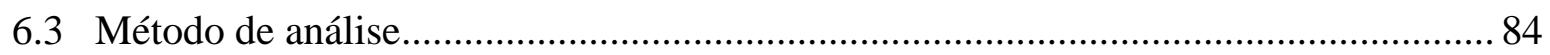

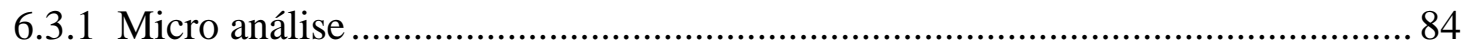

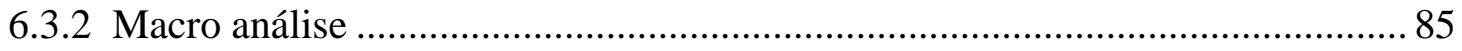

7 A COMERCIALIZAÇÃO DE ETANOL CARBURANTE NO CENTRO-SUL DO

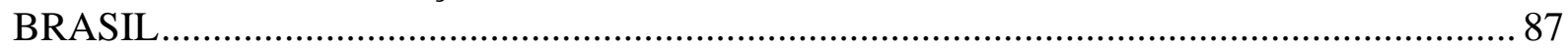

7.1 Comentários sobre a execução das entrevistas sob a ótica metodológica..................... 88

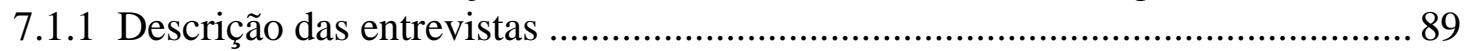

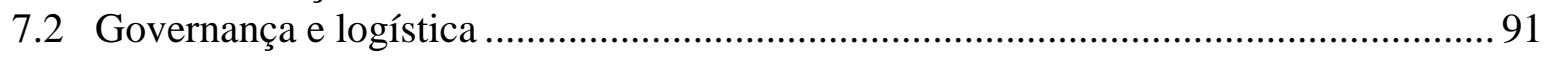

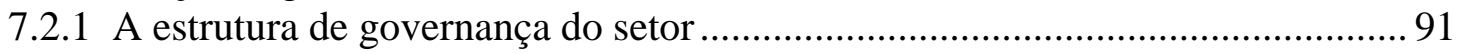

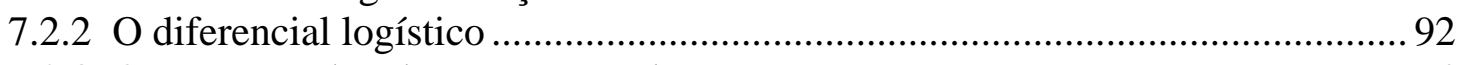

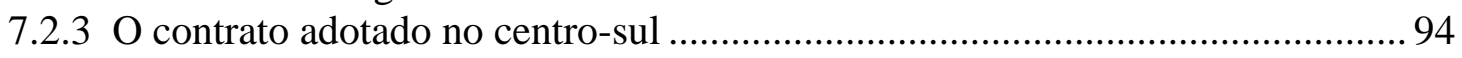

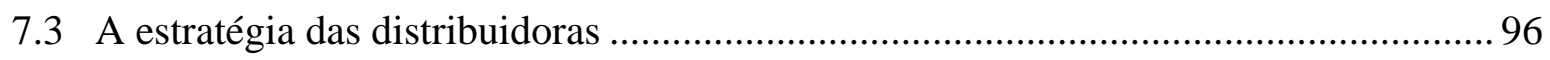

7.3.1 A política de compras de etanol das grandes distribuidoras .............................. 98

7.3.1.1 O prazo dos contratos como reflexo da política de compras das

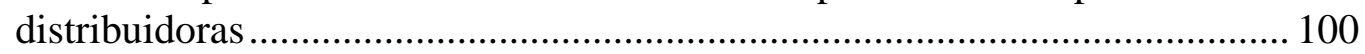

7.3.1.2 O contrato como instrumento estratégico de compras ........................ 100

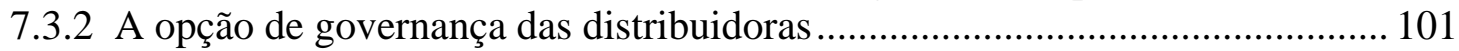

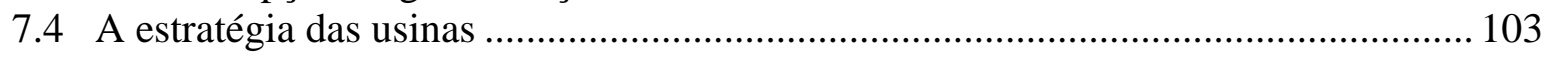

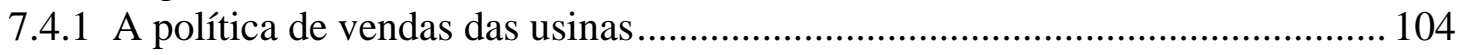

7.4.1.1 Garantia de fluxo de caixa........................................................... 104

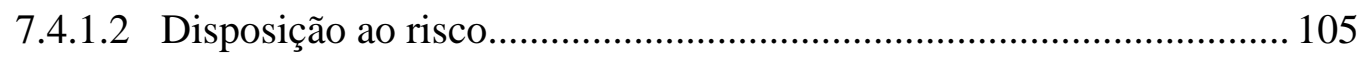

7.4.1.3 A organização dos agentes em grupos de comercialização................. 107

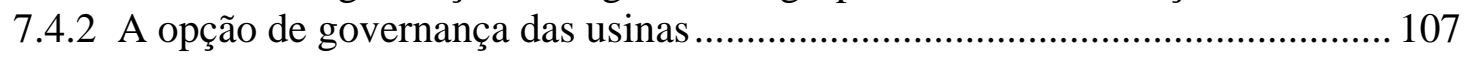

7.5 Ambiente institucional e as diferenças de governança entre hidratado e anidro. ...... 111

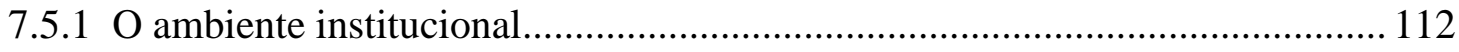

7.5.1.1 A fraude do anidro molhado......................................................... 113

7.5.1.2 Evasão fiscal por triangulação de ICMS ............................................ 113

7.5.1.3 A transferência da responsabilidade de arrecadação do PIS/COFINS

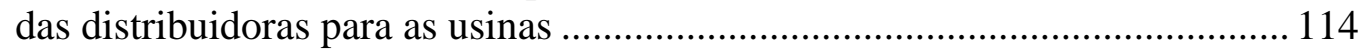

7.5.1.4 A nova lei do embandeiramento................................................... 114 
7.5.2 O reflexo das distorções do mercado sobre a governança do setor................... 115

7.5.2.1 Mudança Institucional e a retomada do Sindicom ............................ 116

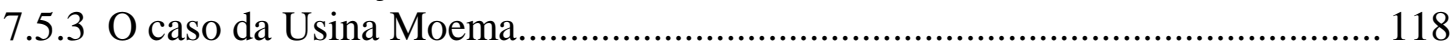

7.5.3.1 A Usina Moema .............................................................................. 118

7.5.3.2 Diferenças na governança do hidratado e anidro no caso da Moema 119

7.6 Conteúdo estruturado sob o modelo teórico de Bogetoft e Olesen (2004) ................. 122

7.6.1 Apresentação gráfica do conteúdo ................................................................... 129

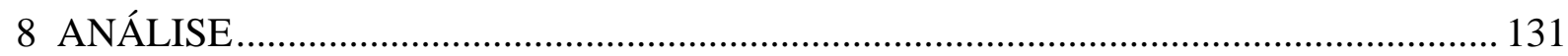

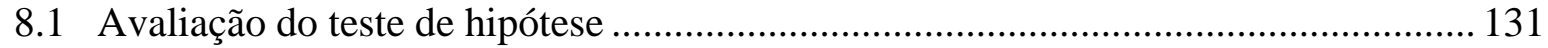

8.2 A racionalidade da relação entre usinas e distribuidoras ........................................ 131

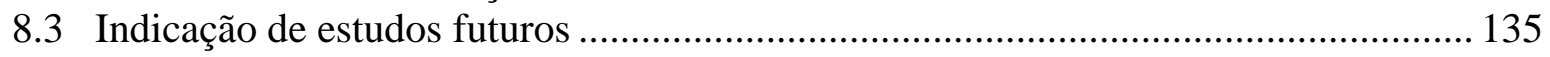

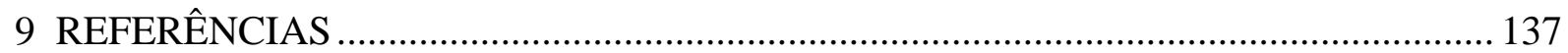

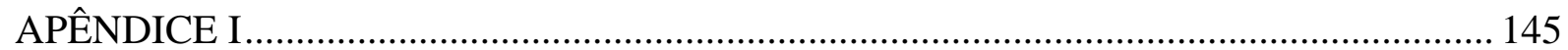


LISTA DE ABREVIATURAS

AEAC: Álcool Etílico Anidro Carburante

AEHC: Álcool Etílico Hidratado Carburante

ANP: Agência Nacional do Petróleo, Gás Natural e Biocombustíveis

CIDE: Contribuição de Intervenção sobre o Domínio Econômico

CIMA: Conselho Interministerial do Açúcar e Álcool

CNPE: Conselho Nacional de Política Econômica

CONSECANA: Conselho dos Produtores de Cana-de-açúcar, Açúcar e Álcool do Estado De São Paulo

IAA: Instituto do Açúcar e Álcool

IPCA: Índice de Preços ao Consumidor Ampliado

MAPA: Ministério da Agricultura, Pecuária e Abastecimento.

MME: Ministério de Minas e Energia

NEI: Nova Economia Institucional

PROÁLCOOL: Programa Nacional do Álcool

SAG: Sistema Agroindustrial

SCA: Sociedade Corretora de Álcool

SINDICOM: Sindicato Nacional das Empresas Distribuidoras de Combustíveis e de Lubrificantes

TRANSPETRO: Petrobras Transporte S.A.

TRR: Transportador Revendedor Retalhista

UNICA: União da Indústria de Cana-de-açúcar 


\section{LISTA DE FIGURAS}

Figura 01 - Elementos e etapas do método científico

Figura 02 - Lucro integrado máximo 34

Figura 03 - Hierarquia de objetivos para o desenho contratual 34

Figura 04 - O subsistema do álcool etílico 43

Figura 05 - O subsistema do etanol carburante $\quad 45$

Figura 06 - Bases de distribuição de combustível 59

$\begin{array}{ll}\text { Figura } 07 \text { - Os principais fluxos de etanol carburante } & 60\end{array}$

Figura 08 - Os três fluxos existentes na distribuição de combustíveis 61

Figura 09 - Cartograma de infra-estrutura para movimentação de petróleo e etanol 62

Figura 10 - Objetivo geral do trabalho $\quad 69$

Figura 11 - Indissociabilidade entre coleta e análise 85

Figura 12 - A sistemática da pesquisa 86

Figura 13 - Disposição geográfica das usinas no centro-sul do Brasil 92

Figura 14 - O diferencial logístico 93

Figura 15 - O Grupo Moema 118

Figura 16 - A racionalidade da relação entre usinas e distribuidoras 133 


\section{PESQUISA E ESTRUTURA}

\subsection{Introdução}

O mercado de etanol no Brasil vem ganhando mais importância desde o lançamento nacional do carro flex, em 2003 (CARVALHO, 2006). Enquanto isso, no mercado internacional, o interesse demonstrado em relação a este biocombustível também é crescente, fruto da pressão política a favor do uso de energia limpa, consagrada a partir da assinatura do Protocolo de Kyoto ${ }^{1}$, em 1999 (JANK, 2006).

Em geral, as pesquisas relacionadas ao setor sucroalcooleiro privilegiam temas voltados ao setor rural e industrial, como a capacidade de produção agrícola e o desenvolvimento tecnológico, dando menor atenção à distribuição. Assuntos como o melhoramento de cultivares e a otimização do processo de fermentação da sacarose são temas que vêem sendo estudados há mais tempo, até porque a desregulamentação da comercialização do etanol no Brasil só foi concluída em 2002.

A questão da distribuição tem grande importância, pois está relacionada à capacidade de abastecimento do mercado e à formação de preço de um produto capaz de influenciar a taxa de inflação doméstica ${ }^{2}$. O entendimento de sua dinâmica contribui para o equacionamento eficiente do fluxo e da logística de abastecimento, fazendo-se necessário para suportar a proposição de políticas públicas, ou mesmo para dar base à tomada de decisões estratégicas por agentes do setor, o que impacta diretamente o crescimento do mercado interno e externo do etanol brasileiro.

Dado que o etanol é um produto sazonal, que carrega todas as idiossincrasias da produção agrícola, uma questão que desafia o setor é construir uma estrutura que governe as relações entre usinas e distribuidoras de combustíveis alinhada às necessidades do mercado. Isto é, formatar relações de suprimento que permitam que o mercado esteja abastecido durante todo

\footnotetext{
${ }^{1}$ O Protocolo de Kyoto, assinado em 1999, contem uma proposta global de ações para reduzir a emissão dos gazes do efeito estufa.

2 O etanol carburante é responsável por 0,44\% da estrutura de ponderação do Índice de Preços ao Consumidor Ampliado (IPCA). O etanol chega a ser responsável por $25 \%$ do volume da mistura que forma a gasolina C, sendo assim ele é capaz de influenciar diretamente a formação de seu preço, a qual responde por 5,02\% do mesmo índice.
} 
ano, independente da sazonalidade da cana e dos riscos das variações climáticas, e também garantam o abastecimento desse mesmo mercado no longo prazo.

No intuito de contribuir para o aumento do conhecimento sobre cadeia produtiva do açúcar e álcool, este trabalho irá discutir a racionalidade econômica ${ }^{3}$ da escolha da estrutura de governança feita pelos agentes do setor.

\subsection{Observação do fenômeno e formulação do problema de pesquisa}

A problematização deste trabalho teve início a partir da constatação de que, praticamente, não existiam até então, ano de 2007, trabalhos publicados que discutissem, especificamente, a estrutura de governança da relação entre usinas e distribuidoras de combustíveis.

Collis e Hussey (2005) comentam que o caminho clássico para a elaboração de um problema de pesquisa está na tentativa de preencher as lacunas do conhecimento. No caso, seguiu-se este caminho, até porque a estrutura de governança da relação imediatamente anterior desta cadeia, a relação entre produtores agrícolas e usineiros, já havia sido descrita em trabalhos acadêmicos por vários pesquisadores, como é o caso de Moraes (1999), Moraes e Shikida (2002) e Neves (1998).

Para alcançar uma definição adequada do problema de pesquisa, buscou-se averiguar qual seria a estrutura de governança vigente. Como esta informação não foi encontrada na literatura, foi feita uma entrevista de natureza exploratória ${ }^{4}$ com um executivo da Sociedade Corretora de Álcool ${ }^{5}$, na qual se averiguou que, naquele momento, primeiro semestre de 2007, a governança em questão se dava, principalmente, a partir de um mix de contratos e mercado spot, tanto para o etanol hidratado ${ }^{6}$, como para o anidro ${ }^{7}$.

\footnotetext{
${ }^{3}$ A racionalidade econômica trata da explicação lógica de um processo sob a ótica econômica. Este conceito será detalhado, ainda neste capítulo, na seção 1.2

${ }^{4}$ A natureza exploratória da pesquisa, assim como a natureza da aplicação de uma entrevista, está na busca por padrões, idéias ou hipóteses, em vez de testar ou confirmar uma hipótese (COLLIS E HUSSEY, 2005).

${ }^{5}$ A Sociedade Corretora de Álcool (SCA) é uma organização privada que comercializa o etanol de uma série de usinas. Detalhes sobre a SCA serão apresentados no capítulo 4 e 7.

${ }^{6} \mathrm{O}$ etanol hidratado é o álcool consumido diretamente pelos automóveis. Este assunto será retomado em detalhes no capítulo 4

${ }^{7} \mathrm{O}$ Etanol anidro é o álcool usado como aditivo à gasolina.. Este assunto será retomado em detalhes no capítulo 4
} 
Tendo observado, por intermédio do depoimento deste agente, que o setor utilizava principalmente um mix de contratos e mercado spot para viabilizar a comercialização do etanol, definiu-se o seguinte problema de pesquisa:

"Qual a racionalidade econômica da escolha de estrutura de governança adotada pelos agentes do setor?”

Antes de prosseguir, vale definir o conceito de racionalidade econômica, usado na formulação deste problema.

Para Saes (1995), a racionalidade econômica é a lógica que suporta a condução de um determinado processo sob a ótica da economia. No caso, seria a lógica capaz de explicar a escolha da estrutura de governança, que está sendo feita pelos agentes do setor. A autora (op. cit.) salienta que a indicação e compreensão dos determinantes do processo que estiverem em pauta, são fundamentais para o estabelecimento da racionalidade econômica que explica sua ocorrência.

Para complementar o entendimento do problema de pesquisa proposto, vale citar que Ferreira (1974, p. 1201) define o termo racional, raiz da palavra racionalidade, como aquele "que usa da razão” e Chaui (2004, p. 84) define a razão como o "conhecimento verdadeiro da realidade.”

\subsubsection{O problema de pesquisa e seu objetivo implícito}

Collis e Hussey (2005) classificam uma pesquisa como básica ou aplicada, que, segundo os autores, é a classificação padrão na pesquisa em administração de empresas. Nesta classificação a pesquisa aplicada refere-se à aplicação de descobertas a um problema já existente, e, a pesquisa básica, refere-se ao aumento do conhecimento geral.

O objetivo de uma pesquisa está diretamente relacionado ao problema selecionado (RICHARDSON, 1999). O objetivo delimita o escopo do problema, e o problema qualifica o objetivo da pesquisa. Sendo assim, de acordo com o problema apresentado anteriormente, entende-se que esta pesquisa teve como objetivo a formulação de um modelo teórico, enquanto se preocupou em propor um modelo lógico para a ocorrência de certo fenômeno, a partir de um determinado aporte teórico. Desta forma, pode-se dizer que o objetivo implícito 
do trabalho se ajusta à classificação de pesquisa básica, buscando o aumento do conhecimento geral.

\section{Epistemologia ${ }^{8}$ da pesquisa e estrutura do texto}

Antes de prosseguir com o aprofundamento nas fases que compõem esta pesquisa, serão apresentadas nesta seção: a discussão epistemológica deste trabalho e a forma que se pretende usar para estruturar o texto a partir da próxima seção.

\subsubsection{O paradigma de pesquisa adotado}

Esta seção se propõe a esclarecer quais foram os pressupostos ontológicos adotados neste trabalho, ou seja, a perspectiva como pesquisadores vêem o mundo e tomam como verdadeiro um determinado conjunto de fenômenos, ou, como coloca Richardson (1999): os pressupostos filosóficos adotados pelos pesquisadores. Collis e Hussey (2005) definem esta perspectiva como sendo as filosofias e suposições das pessoas sobre o mundo e a natureza do conhecimento.

Collis e Hussey (2005) utilizam-se do termo paradigma de pesquisa para indicar a corrente filosófica assumida pelos pesquisadores em seus trabalhos científicos.

Richardson (1999) e Collis e Hussey (2005) insistem na importância de que esteja claro para os próprios pesquisadores e para o leitor de um trabalho científico o paradigma de pesquisa adotado para conduzir determinado trabalho. Richardson (1999, p. 31-32) comenta que "um aspecto fundamental, muitas vezes esquecido, que afeta todo o trabalho de pesquisa são os pressupostos filosóficos do pesquisador" e que "essa perspectiva orientará a escolha do método, metodologia e técnicas a utilizar em uma pesquisa.” Em concordância, Collis e Hussey (2005) também afirmam que a escolha do paradigma de pesquisa tem implicação direta na escolha da metodologia.

Collis e Hussey (2005) apresentam os paradigmas positivista e fenomenológico como sendo os principais em trabalhos no âmbito da administração de empresas. Segundo os autores recém citados, estes paradigmas estariam em extremos opostos de um contínuo entre

\footnotetext{
${ }^{8}$ Na definição de Collis e Hussey (2005, p.56): “A epistemologia ocupa-se do estudo do que aceitamos como sendo conhecimento válido. Isso envolve um exame da relação entre o pesquisador e o que está sendo pesquisado.”
} 
objetividade e subjetividade, em que o paradigma positivista seria o mais objetivo, e o paradigma fenomenológico seria o mais subjetivo.

Neste trabalho será usado o termo paradigma de pesquisa, proposto por Collis e Hussey (2005), ao se referir a uma determinada corrente filosófica. Também será adotada a proposta de delimitação das discussões no âmbito das correntes positivista e fenomenológica sugerida pelos autores.

Cabe colocar neste momento, que nesta pesquisa foi adotado o paradigma de pesquisa positivista.

\subsubsection{Estrutura do texto}

De acordo com Pease e Bull (1996), o método científico é composto por cinco elementos básicos: meta, modelo, dados, avaliação e revisão. Richardson (1999) acrescenta que existem sete etapas a serem cumpridas para que um trabalho esteja de acordo com o método científico, a saber: observação, formulação do problema, informações referenciais, hipóteses, predição, experimento e análise.

A Figura 1 apresentado a seguir, traz estes dois modelos. Para que seja possível uma visualização mais ampla da questão, elementos e etapas estão sendo apresentados lado a lado, evidenciando o paralelo entre ambos, pelo uso de cores. 

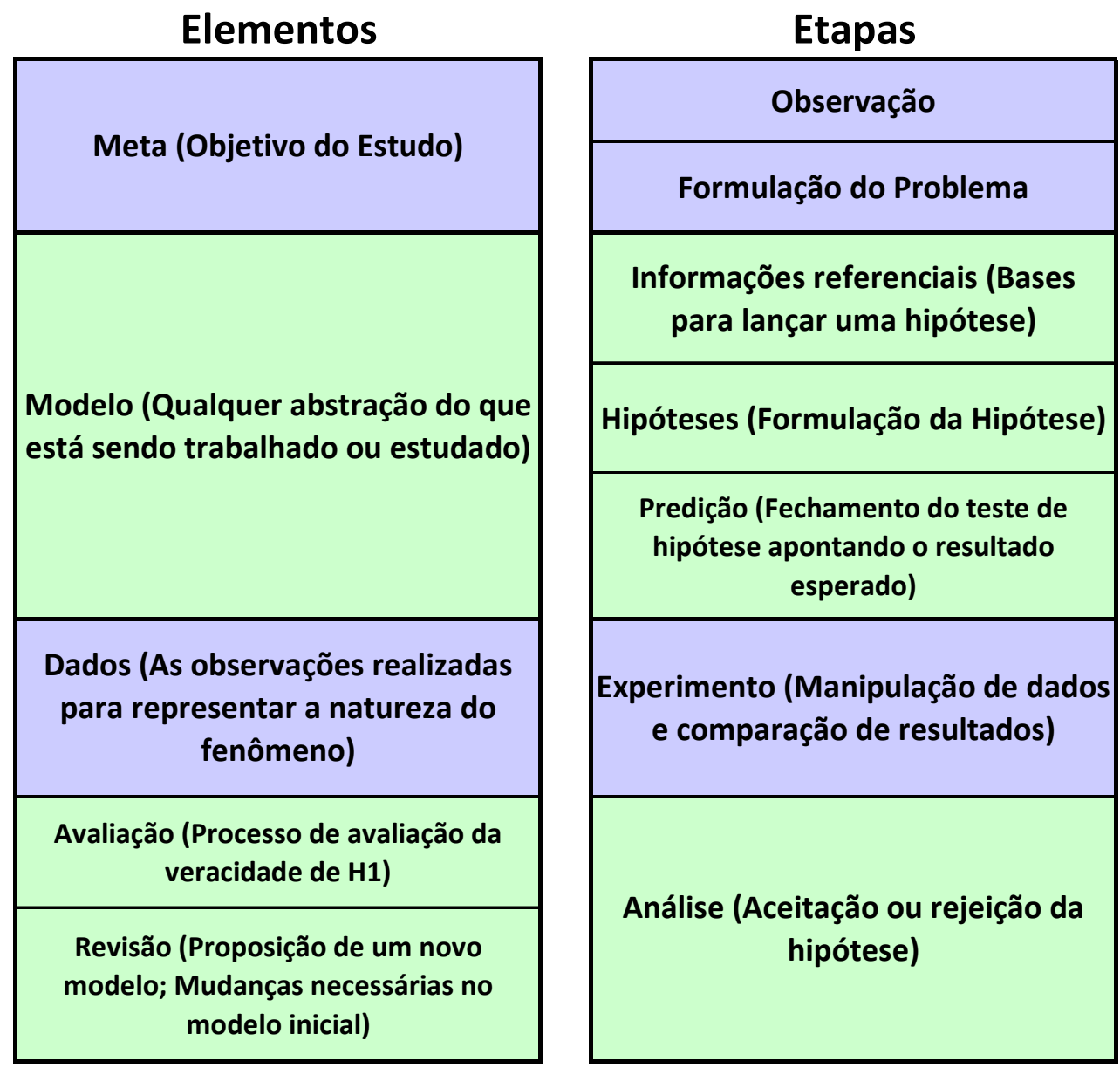

Figura 1: Elementos e etapas do método científico

FONTE: Adaptado pelo autor de Pease e Bull (1996) e Richardson (1999)

Uma dissertação de mestrado, assim como todo trabalho acadêmico, independente do paradigma de pesquisa escolhido, seguirá sempre o Método Científico. Aproveitando o conteúdo e didática inerentes aos modelos recém apresentados, resolveu-se utilizá-los para estruturar o texto deste trabalho. Especificamente, o texto será estruturado a partir das etapas propostas por Richardson (1999), cujo entendimento é ampliado ao conjugar tais etapas com os elementos do método científico proposto por Pease e Bull (1996).

As primeiras duas etapas, observação e formulação do problema de pesquisa já foram apresentadas neste mesmo capítulo, na seção 1.2. A próxima seção abordará a terceira etapa, a etapa da compilação de um conjunto de informações já existentes sobre o fenômeno em estudo: a etapa da reunião das informações referenciais. 


\subsection{Informações referenciais}

Conforme a Figura 1, entende-se que após a definição do problema de pesquisa, deve-se pensar na formulação das hipóteses, sendo recomendável se valer de informações disponíveis sobre o fenômeno estudado para balizar o lançamento destas hipóteses. Richardson (1999, p. 27) apresenta a definição para o termo informações referenciais como "tudo que já foi publicado sobre o fenômeno" em foco.

No caso deste trabalho, a busca por informações referenciais foi feita sob dois ângulos: o de visão específica, tentando conhecer o setor, a cadeia de suprimentos, seus agentes e suas características peculiares, e o de visão teórica, focando no estudo da teoria econômica voltada à elucidação da forma como se dá as transações entre agentes, de maneira genérica.

Collis e Hussey (2005, p. 121) preferem o uso do termo estrutura teórica para apontar o conjunto das informações referenciais vindas da teoria. Para estes autores, "uma estrutura teórica é um grupo de teorias e modelos da literatura que sustentam um estudo de pesquisa positivista.”

A proposta adotada neste trabalho para a formação da estrutura teórica baseou-se na utilização da Nova Economia Institucional (NEI) como aporte teórico geral e na proposta de avaliação contratual de Bogetoft e Olesen (2004) como modelo analítico.

A estrutura de governança é um atributo da transação entre agentes econômicos. Sendo a ocorrência de determinada estrutura de governança o fenômeno em estudo, optou-se por um aporte teórico que tem a transação como unidade de análise. A NEI apresenta duas vertentes: microinstituções e macroinstituições. Uma revisão desta teoria, passando pelas contribuições de autores como Coase (1937 e 1960), Williamson (1985 e 1996) e North (1990, 1994a), será o tema do capítulo 2 deste texto.

Para analisar o comportamento dos agentes foi escolhido o modelo de avaliação contratual de Bogetoft e Olesen (2004) que se propõe a discutir os determinantes ao uso de contratos a partir da NEI. O capítulo 3 deste texto será dedicado integralmente a este tema.

O Capítulo 4 será dedicado à apresentação de um resumo das informações referencias específicas da cadeia produtiva do açúcar e álcool recolhidas, principalmente, por meio de 
revisão da literatura e consultas a fontes públicas de dados. Para a elaboração deste capítulo foi necessária a aplicação de uma nova entrevista exploratória para complementar o entendimento do setor, devido à grande dificuldade de encontrar material apropriado sobre determinados assuntos. Desta vez, a entrevista foi feita com executivos da Petroluna Distribuidora de Petróleo.

A entrevista com a Petroluna foi essencial para compreender como ocorre o fluxo logístico na distribuição de etanol. Esta entrevista também ajudou a melhorar o entendimento do ambiente institucional deste setor.

O Capítulo 2, apresentado a seguir, será dedicado a uma revisão do aporte teórico deste trabalho, a Nova Economia Institucional. 


\section{NOVA ECONOMIA INSTITUCIONAL}

O objetivo desse capítulo é introduzir a base teórica para análise das transações. Para definir o fenômeno que será estudado, a transação, é necessário conceituar a firma, uma vez que a transação ocorre entre as firmas. Como veremos, a firma pode ser definida como uma função de produção (teoria neoclássica) ou como uma entidade minimizadora de custos de transação, na versão da Nova Economia Institucional (NEI). A transação, objeto de análise da NEI, nada mais é que uma troca de direitos de propriedade. A depender de como tais direitos serão definidos dar-se-ão distintas estruturas de governança.

\subsection{Nova Economia Institucional e os custos de transação}

Até o início do século XX, os economistas, representando a linha de pensamento neoclássico, acreditavam que a melhor forma de se definir uma firma era por meio de uma função de produção, que o sistema de preços era sempre suficiente e eficiente na coordenação da atividade econômica, e que os agentes tomavam suas decisões de forma racional como se fossem o espelho de uma função de utilidade.

Na década de 30, as contribuições de dois autores, Commons (1934) e Coase (1937 e 1960), deram início a uma nova corrente de pensamento, a Nova Economia Institucional.

Coase (1937), a partir de discussões sobre a gênese da firma e os limites de sua extensão, constata que as atividades produtivas, assim como as de coordenação da produção, poderiam ocorrer tanto internamente à firma como externamente a ela utilizando-se do mercado ${ }^{9}$. Coase argumenta que existem custos para se usar o mercado, e, quando esses custos são proibitivos, vale mais a pena internalizar a atividade econômica à firma ${ }^{10}$.

O reconhecimento da existência de custos para se usar o mercado, indicado por Coase em 1937, é a "pedra fundamental" do surgimento do conceito de Custo de Transação, algo negligenciado pelo pensamento neoclássico.

\footnotetext{
${ }^{9}$ Mais tarde, Arrow (1974) irá reforçar a idéia de Coase quanto à função de coordenação da atividade econômica pela firma.

${ }^{10}$ Coase sugere que a preocupação por evitar desperdícios está no plano central dos interesses da firma. Williamson (1991) classifica essa postura como first order economising.
} 
A contribuição de Commons (1934) veio no sentido de se adotar a transação como objeto de análise central da economia, ao invés do sistema de preços e geração de lucros focados pelos neoclássicos.

A Nova Economia Institucional teve seu início a partir daí, focando a transação como objeto de análise e reconhecendo a existência de custos (custos de transação) além daqueles postulados pelos neoclássicos como custos de produção.

A NEI reconhece que, na realidade, e, diferente do que prega a economia neoclássica, o agente econômico não dispõe de toda a sorte de informações necessárias para compor uma tomada de decisão perfeita. A NEI também considera que o agente econômico pode ser oportunista e que sua racionalidade é limitada ${ }^{11}$. Essa condição, de assimetria informacional imposta a um agente econômico com tais características, é uma das fontes geradoras dos custos de transação. Vale citar que a assimetria de informação é a condição básica para a ocorrência de fenômenos como: Moral Hazard ${ }^{12}$ (ARROW, 1984) e Seleção Adversa ${ }^{13}$ (AKERLOFF, 1970).

O conceito de custo de transação evoluiu desde o primeiro insight de Coase em 1937. Furubotn e Richter (1991), usando uma abordagem abrangente, classificam aos custos de transação como aqueles necessários para se colocar o mecanismo econômico e social em funcionamento. Para Cheung (1990), são os custos de elaboração e negociação de contratos, mensuração e negociação de direitos de propriedade, monitoramento do desempenho e organização de atividades.

A ligação entre a ocorrência de custos de transação e a definição de direitos de propriedade, apontada por Cheung (1990) e por autores como Barzel (1989) e North (1990), será discutida na seção 2.2, que também explora a análise microinstitucional, abordando os temas da Economia dos Custos de Transação e das formas híbridas de organização. Por fim, na seção 2.3 será tratado o tema macroinstitucional, com especial atenção às contribuições de Douglas North (1990) e Eric Brousseau (2006).

\footnotetext{
11 Tais pressupostos comportamentais serão aprofundados durante a discussão da Economia dos Custos de Transação, na seção 2.2.1

${ }^{12}$ Moral Hazard, ou risco moral, refere-se à situação oportunista em que uma das partes de uma transação detém uma informação privilegiada no momento pós-contratual, podendo tirar proveito disso sobre sua contraparte.

${ }^{13}$ Seleção Adversa refere-se à situação oportunista em que uma das partes de uma transação detém uma informação privilegiada no momento pré-contratual, podendo tirar proveito disso sobre sua contraparte.
} 


\subsection{Direitos de propriedade e custos de transação}

Neste ponto, já temos a definição do conceito de firma que será utilizado para a análise. Dado o interesse em entender as relações entre firmas e como elas organizam a produção em função das relações na cadeia produtiva, o conceito de firma como uma entidade que minimiza custos de transação se torna adequado para nosso objeto de análise. As transações e a configuração das firmas serão, portanto, guiadas pelo interesse em minimizar os custos de transação e mais especificadamente sobre como os direitos de propriedade entre os bens transacionados serão definidos.

De acordo com Cooter e Ulen (1988) direitos de propriedade são conceituados como o conjunto de direitos sobre um recurso que o dono está livre para exercer, e cujo exercício é protegido contra a interferência de outros agentes.

Os direitos de propriedade estão ligados à característica de escassez dos bens. Sempre que um bem for finito, ou seja, escasso, a definição de seus direitos de propriedade irá influenciar a eficiência econômica de seu uso, como descrito por Hardin (1968), analisando o fenômeno da Tragédia dos Comuns ${ }^{14}$.

A relação básica entre o conceito de direito de propriedade e a economia vem a partir do reconhecimento de que a transação é uma troca de direitos de propriedade. Essa relação foi inicialmente indicada por Demsetz (1967).

Em sua visão, Demsetz (1967) retoma o conceito de que a imperfeição na definição de direitos de propriedade é capaz de gerar externalidades, positivas ou negativas. Sendo assim, o autor sugere que, enquanto os custos de internalizar as externalidades forem menores que os ganhos de fazê-lo, os agentes assim o farão, promovendo a definição dos direitos de propriedade, num processo de busca por eficiência.

Alchian e Demsetz (1972) também discutiram a ligação entre direito de propriedade e a gênese da firma. Os autores mostraram que a garantia de direitos de propriedade é uma condição necessária e imprescindível para gerar os incentivos necessários para que os

\footnotetext{
${ }^{14}$ Situação em que determinado bem, cuja propriedade não está definida, é explorado desordenadamente e ineficientemente pelos agentes econômicos.
} 
“supervisores" existam e desempenhem seu papel fundamental no que se refere ao trabalho coletivo.

Coase (1960) também contribuiu para a compreensão da economia dos direitos de propriedade. O autor observou que, na ausência de custos de transação, a alocação ou distribuição inicial de direitos de propriedade sobre as dimensões dos bens não terá importância, pois os agentes negociarão a transferência desses direitos a custo zero, podendo realocá-los eficientemente. Essa constatação, denominada como Teorema de Coase, evidencia o elo entre a eficiência econômica e a definição dos direitos de propriedade. Entretanto, como os custos de transação são, em geral, positivos, a alocação dos direitos de propriedade entre os agentes que transacionam importa.

Sobre esta questão, Williamson (1985 e 1996) agregou um importante instrumental de análise ao propor que as transações possuem três dimensões que devem ser consideradas para a análise da alocação dos direitos de propriedade, e, conseqüentemente, análise da economia dos custos de transação: a especificidade dos ativos, a freqüência e a incerteza.

\subsubsection{Economia dos Custos de Transação (ECT): abordagem da governança}

Considerando os pressupostos de racionalidade limitada e oportunismo, Williamson (1985 e 1996) argumenta que a especificidade de um ativo é o grau ao qual esse ativo pode ser reempregado sem perda de valor. Quanto mais específico for o ativo, ou o investimento em determinado ativo, mais difícil será sua realocação sem perda de valor. Ainda, quanto maior for a especificidade dos ativos em determinada relação comercial, maior a dependência entre as partes. Dessa forma, a presença de ativos específicos deverá aumentar a ocorrência de custos de transação.

Williamson (1985 e 1996) aponta seis tipos de especificidades de ativos que devem ser considerados em qualquer análise: locacional, física, humana, marca, temporal e de ativos dedicados (investimentos em um cliente específico).

A freqüência das transações, a segunda dimensão comentada anteriormente, também é relevante na análise, sendo que, quanto maior esta freqüência, menor serão os custos de transação (WILLIAMSON, 1985 e 1996). Os custos de se contratar e monitorar determinada transação estariam diluídos devido às várias repetições da mesma. 
Incerteza, a última dimensão apontada por Williamson (1985 e 1996), relaciona-se com a falta de conhecimento quanto a possíveis acontecimentos que podem influenciar a transação. Neste caso a incerteza poderia estar sendo gerada pelos próprios agentes ou pelo ambiente. No que se refere aos custos de transação, podemos esperar que num ambiente de alto grau de incerteza, estes serão elevados.

A incerteza apontada por Williamson refere-se ao conceito trazido por Knight (1972) sobre eventos que não se pode prever a ocorrência, algo distinto do conceito de risco, que se refere a eventos cuja probabilidade de ocorrência pode ser modelada.

Williamson (1985) aponta dois pressupostos comportamentais para compor o arcabouço teórico da ECT.

A racionalidade limitada dos agentes, o primeiro deles, diz respeito à existência de limitação por parte desses agentes em absorver e interpretar toda e qualquer informação pertinente a uma determinada transação. O conceito de racionalidade limitada adotado por Williamson é fruto do trabalho de Hayek (1945), evidenciando a falta de uniformidade da dispersão das informações entre os indivíduos, e do trabalho de Simon (1982), evidenciando a limitação cognitiva do agente econômico e a existência de custos na obtenção de informação.

O segundo pressuposto comportamental da ECT é o de oportunismo, no qual se admite que os agentes podem, em determinada situação, lançar mão desse tipo de comportamento. Farina et al (1997) indicam que o comportamento oportunista é fruto do auto-interesse e das condições criadas por ambientes cuja informação é assimétrica.

A análise de uma cadeia de suprimento sob a ótica da Economia dos Custos de Transação poderá revelar a maneira mais eficiente que os agentes podem transacionar um determinado insumo, em uma abordagem mais completa e realista do que aquela que vê apenas os custos de produção destes insumos para a determinação das estratégias empresariais e, conseqüentemente, a adoção de determinadas formas de governança na cadeia (ZYLBERSZTAJN, 1995). 


\subsubsection{Organizações Híbridas}

A ECT de Williamson prevê três estruturas básicas de governança: mercado, contratos e firmas. Dentro dessa estrutura de análise, Ménard (2004) propõe que os contratos, tratados até aqui de forma contínua e uniforme, poderiam ser vistos em sua verdadeira complexidade e multiplicidade.

Ménard (2004) classifica dentro da estrutura de governança denominada “contratos”, uma série de formas denominadas por ele como híbridas. Tais arranjos, apesar de apresentarem características singulares, poderiam ser agrupados no conjunto contratual, pois nenhum deles se utiliza do mecanismo de preços como no caso dos mercados, nem estariam sob a tutela de uma mesma hierarquia como no caso de uma firma. O autor dá como exemplo de forma híbrida: subcontratação, redes de firmas, canais de distribuição, franchising, parcerias e alianças.

As formas híbridas são classificadas por Ménard (2004) como: confiança, redes de relacionamento, liderança e governança formal. Essas quatro estruturas são ordenadas no contínuo dos contratos, levando em conta o grau de hierarquização de sua estrutura relacional. A estrutura de “confiança” fica posicionada mais próxima ao mercado, enquanto a “governança formal” é a mais próxima à hierarquia.

Ménard (2004) sustenta que as formas híbridas com características mais próximas do mercado têm sua estrutura contratual mais flexível, a qual deverá ser mantida por meio de incentivos à cooperação. No outro extremo, onde a estrutura relacional está mais próxima à hierarquia, a flexibilidade no relacionamento será pequena, sendo que o monitoramento e os mecanismos de proteção contratual serão os mais eficientes para manter tal estrutura. Dessa forma, observa-se que a estrutura de governança está relacionada à necessidade ou não de diferentes definições dos direitos de propriedade entre os bens que estão sendo transacionados.

Entretanto, o efeito da definição dos direitos de propriedade sobre a economia só será verificado se houver segurança de que suas prerrogativas serão resguardadas. Eggertsson (1990) discute a relevância dos mecanismos capazes de proteger os direitos de propriedade, indicando que, em última análise, caberá tanto ao Estado como aos detentores dos bens se 
preocuparem com a proteção desses direitos. Eggertsson (1990) evidencia a função do Estado no contexto dos direitos de propriedade, algo que foi negligenciado por Demsetz (1967).

\subsection{Aporte macroinstitucional}

O grau de definição e proteção dos direitos de propriedade é apontado como determinante dos custos de transação por Barzel (1989). Tal colocação é incorporada por North (1990) na discussão da influência do ambiente institucional sobre as transações, assunto que será explorado mais profundamente a seguir.

\subsubsection{Instituições e organizações}

Instituições são o conjunto de regras que estruturam as relações humanas. De acordo com North (1990), instituições são “as regras do jogo”, ou seja, as regras que orientam a interação entre as pessoas, e, conseqüentemente, entre os agentes econômicos.

De forma geral, à medida que as instituições definem os “contornos” da interação humana, elas diminuem a incerteza desses relacionamentos (NORTH, 1990).

O conceito de "regra do jogo" deve ser compreendido não apenas pela parte da existência do regramento, mas também pelo mecanismo que garante seu cumprimento (NORTH, 1994a). A tomada de decisão dos atores pode ser muito distinta à medida que eles sabem que podem ser punidos, ou não, pelo descumprimento de uma determinada regra.

As instituições, à medida que definem as regras do jogo, acabam definindo toda uma estrutura de incentivos e punições a que estarão sujeitos os agentes, o que também pode ser chamado de arcabouço institucional.

As instituições podem ser formais ou informais, sendo que, as indicadas pelo Estado são denominadas formais, e aquelas, fruto de outras convenções, são denominadas informais. North (1990) considera ambos os tipos como relevantes para compor o ambiente institucional.

Um exemplo que pode ilustrar a ocorrência de regras formais no Sistema Agroindustrial do Açúcar e Álcool é o da obrigatoriedade da adição de corante laranja ao anidro pelas usinas. Tal regra é uma resolução imposta pela ANP, Agência Nacional do Petróleo, Gás Natural 
Biocombustíveis, que passou a vigorar em 2006 visando diminuir a fraude nesse mercado ${ }^{15}$ (BRAGATO, 2006).

As instituições informais são formadas por regras, padrões individuais, costumes e outras convenções compreendidas na cultura de uma população (NORTH, 1990; 1994a). No mercado de etanol, um exemplo de padrão de comportamento do consumidor, seria o hábito do brasileiro de desconfiança, pois o condutor de veículos automotivos ainda tem resistência ao uso de etanol por medo de que o uso deste combustível venha a causar um desgaste no automóvel muito maior do que ocorreria com o uso da gasolina. A motivação desta crença veio da época do Proálcool, Programa Nacional do Álcool, quando realmente a tecnologia ainda não era dominada completamente, o que não é mais uma verdade em 2007 (CARVALHO, 2007).

No que se refere às organizações, North (1990; 1994a; 1994b) define que estas surgem por meio da agregação de atores (indivíduos) com um objetivo em comum. Portanto, firmas, clubes, partidos políticos, organizações de classe, são alguns exemplos de organizações, sendo que essas podem ser públicas ou privadas.

Saes (2000) classifica as organizações segundo as formas de vinculação dos agentes econômicos, o tamanho, e as formas de monitoramento e incentivos adotados. Assim, surgem organizações de adesão voluntária ou compulsória, grandes grupos ou pequenos, organizações de cooperação espontânea ou induzida e grupos privilegiados, intermediários e latentes.

No caso do $\mathrm{SAG}^{16}$ do etnol, pode-se citar a UNICA ${ }^{17}$, União da Agroindústria da Cana-deaçúcar, como exemplo de organização de classe, e o Ministério da Agricultura Pecuária e Abastecimento, MAPA, como a organização pública responsável por grande parte das leis que governam o setor agrícola. Vale salientar que o MAPA é uma organização, enquanto o conjunto de leis que ele define faz parte do ambiente institucional.

\footnotetext{
${ }^{15}$ Para evitar que o anidro seja comprado ilegalmente, adicionado de água e vendido no mercado de hidratado. A descrição completa deste tipo de fraude será feita na seção 7.5.1.1

${ }^{16}$ SAG: Sistema Agroindustrial

${ }^{17}$ A União da Indústria de Cana-de-açúcar (UNICA) é a maior organização representativa do setor de açúcar e etanol do Brasil, tendo criada em 1997. As mais de 100 companhias associadas à UNICA são responsáveis por mais de $50 \%$ do etanol e $60 \%$ do açúcar produzidos no Brasil.
} 
A matriz de incentivos e punições, o arcabouço institucional, determina um conjunto de oportunidades e ameaças a que os agentes econômicos ficam sujeitos. Esses agentes, as organizações, irão direcionar suas estratégias em função desse conjunto de oportunidades e ameaças. Exemplificando: se um ambiente tem instituições que incentivam ações oportunistas, as organizações irão se especializar nesse tipo de comportamento para melhor aproveitar as oportunidades que as cercam.

\subsubsection{Instituições e custos de transação}

North (1994a) sugere que a observação dos determinantes da ocorrência de custos de transação evidencia a íntima relação entre o ambiente institucional e a presença dos mesmos.

O primeiro determinante apontado por North é o custo de quantificação dos atributos de valor dos bens, serviços ou do desempenho dos agentes. Quantificar esses atributos engloba o custo de mensurar não só as dimensões físicas dos atributos do objeto de troca, como também as dimensões dos direitos de propriedade incluídos na troca. Para North (1994a), as dimensões dos direitos de propriedade são aquelas que definem os usos, a renda potencial e a alienação dos bens.

O segundo determinante apontado por North é o tamanho do mercado, pois essa característica determina se o intercâmbio será pessoal ou impessoal. Nessa linha de pensamento, quanto maior o mercado, maior a probabilidade das relações serem impessoais.

No intercâmbio pessoal existem fatores que podem contribuir para amenizar a necessidade de especificações detalhadas na transação. Esses fatores são: o conhecimento prévio entre os atores, o grau de parentesco, a amizade e a constância dos contatos.

A influência do conhecimento pessoal prévio, da freqüência das interações e da preocupação com negócio futuros sobre a tomada de decisão dos agentes é um tema também discutido por Klein (2000). O autor indica que tais fatores podem levar os atores a se auto policiar, selfenforcement, no intuito de cumprir determinados acordos. Em determinadas situações, esse auto-esforço seria imprescindível para viabilizar certas relações comerciais.

O terceiro determinante apontado por North (1994a) é a capacidade do sistema jurídico em fazer cumprir os contratos. North comenta que a dificuldade maior das sociedades é o custo 
do sistema jurídico, pois é necessário que o sistema seja eficiente a um custo viável à economia.

O quarto determinante nessa análise é a ideologia e percepção dos agentes. A forma como os agentes percebem o mundo, e avaliam suas opções, é fundamental para compreender sua tomada de decisão, ou seja, compreender como os agentes optam frente às oportunidades que se apresentam a eles.

A relevância da análise comportamental sugerida por North é bastante influenciada pelo trabalho de Herbert Simon (1982). Nesse sentido, deve-se considerar que os indivíduos têm ideologias e percepções da realidade diferentes, e formam constructos mentais distintos de acordo com suas características intrínsecas e pela influência de seus conhecimentos adquiridos e da cultura a que foram expostos. Para North, deve-se respeitar a diferença entre os constructos mentais das pessoas para compreender suas atitudes e poder avaliar corretamente a incidência de custos de transação numa economia (NORTH, 1994b).

\subsubsection{Instituições e desempenho econômico}

As instituições provêem condições para que a interação entre os indivíduos possa ocorrer. Como apontado anteriormente, o arcabouço institucional é capaz de diminuir a incerteza na relação entre os atores, estabelecendo uma estrutura estável para a interação humana (NORTH, 1990).

Um ambiente que permite a interação entre as pessoas pode promover a cooperação entre elas, conseqüentemente, levando ao aparecimento de ganhos econômicos provenientes da especialização (NORTH, 1990). Nesse sentido, pode-se dizer que um ambiente institucional que favorece a cooperação entre os agentes é um ambiente que promove o crescimento econômico.

Quanto à importância e a função das instituições no que se refere ao desempenho econômico, North se contrapõe ao modelo neoclássico em que os agentes econômicos são sempre racionais e têm acesso pleno às informações para tomarem suas decisões. Para North, o modelo neoclássico só é aceitável num mundo em que os custos de transação forem inexistentes, como já apontava Coase (1960) em seu artigo The Problem of Social Cost. 
North (1994a) sugere que, na realidade, os mercados sempre apresentam um grau de imperfeição, sendo que o mercado perfeito, aquele em que não há ocorrência de custos de transação, praticamente não existe. Sendo assim, é necessário levar em conta a dificuldade dos agentes em obter informação e como eles irão processá-la, ou seja, levar em conta os custos de transação a que os agentes estão expostos. Tais custos são função do ambiente institucional, pois é esse ambiente que irá modular o grau de definição e proteção dos direitos de propriedade equacionados nas transações. Quanto maior for a capacidade do arcabouço institucional de oferecer definição e proteção dos direitos de propriedade a baixos custos, menor será o grau de imperfeição do mercado.

De acordo com a linha de análise proposta por North, entende-se que as instituições são imprescindíveis para a criação dos mercados à medida que são elas, somadas às restrições normais da economia, que definem o conjunto de oportunidades a ser explorado pelos agentes ao desempenhar a atividade econômica.

Concluindo, pode-se dizer que a tecnologia e as instituições definem os custos de produção, pois a tecnologia usada define os custos de transformação, e o ambiente institucional define os custos de transação.

\subsubsection{Mudança institucional}

North sugere que o processo de mudança institucional é fruto da permanente relação entre as instituições e organizações. As fases desse processo estão descritas a seguir (NORTH, 1990; 1994a).

O processo tem início à medida que as organizações detectam uma nova oportunidade no ambiente. Nesse caso, a percepção de uma nova oportunidade pode ser fruto de uma mudança no ambiente, criando condições onde não havia antes, ou pode ser resultado de uma mudança na forma como o agente interpreta o ambiente à sua volta. No segundo caso, a aquisição de determinado conhecimento pode ser a base para uma mudança na forma como o agente analisa o conjunto de oportunidades a que está exposto.

As opções que levam à mudança institucional são geralmente determinadas por um misto de mudanças externas e aprendizado interno. 
Tomando como exemplo o caso do aquecimento global, fenômeno intimamente ligado ao mercado de etanol carburante, pode-se verificar o modelo sugerido por North da seguinte forma: organizações, como a comunidade científica, foram percebendo o fenômeno a partir de mudanças no ambiente externo, como por exemplo, o aumento dos níveis de gás carbônico na atmosfera. Porém, somente nos últimos anos, a partir do suporte de tecnologias mais avançadas, os cientistas conseguiram avaliar melhor o fenômeno que estava ocorrendo.

North atribui à percepção dos agentes o início do processo de mudança. Sendo assim, diferentes constructos mentais vão influenciar a forma que os agentes avaliam suas oportunidades.

A alteração dos preços relativos é uma mudança no ambiente externo que pode influenciar a percepção dos agentes. Por outro lado, uma mudança no modelo mental, gerada pela aquisição de determinado conhecimento, pode gerar uma mudança no preço relativo percebido (apesar do preço não se alterar nominalmente, a percepção de valor se altera), levando ao mesmo efeito de uma variação real de preços.

À medida que os agentes vislumbram novas oportunidades, eles passam a investir na aquisição de conhecimento e capacitação para se tornarem aptos a tirar o maior proveito possível da circunstância vigente.

O aquecimento global foi o ponto de partida para que vários países se propusessem a aumentar o uso de biocombustíveis em suas matrizes energéticas. Vislumbrando o aumento potencial no mercado de etanol carburante, organizações públicas e privadas estão investindo no desenvolvimento de tecnologias para produzir etanol a partir de celulose a custo competitivo. Só a Shell adquiriu participação em três empresas de biotecnologia: Iogen, Codexis e Choren (BOUÇAS, 2007).

Além de investir em conhecimento e capacitação própria, as organizações tentam canalizar os investimentos públicos para as áreas de especialização que, em sua visão, aumentam suas perspectivas de sobrevivência (NORTH, 1994a). Essa articulação é chamada de lobbing.

Os agentes podem demandar uma reforma do arcabouço institucional tendo em vista garantir as melhores condições para suas atividades, para aproveitar melhor as oportunidades 
percebidas, para se proteger de ameaças, ou mesmo para criar oportunidades que lhes favoreçam e garantam sua autopreservação. Suas ações podem imprimir mudanças tanto no âmbito formal como informal das instituições.

Mudanças nas instituições formais, como a aprovação de uma nova lei, podem ser abruptas, porém as mudanças nas instituições informais são geralmente gradativas (NORTH, 1990).

A articulação da reforma institucional é feita mediante os agentes políticos que devem representar seu eleitorado frente ao poder legislativo.

Em algumas situações, a competência dos agentes, como por exemplo: os empresários, é maior no âmbito da articulação política do que no campo econômico. Isso pode ocorrer porque os custos de transação e poder de barganha dos agentes são diferentes no mercado político e no mercado econômico. De qualquer forma, os atores sempre irão avaliar se o investimento em articular alguma reforma institucional é válido frente aos custos de tal ação.

Para North (1990; 1994a), a permanente relação entre instituições e organizações em um contexto econômico de escassez, e, portanto, de competição, é o fator chave para a mudança institucional. O autor também indica que os fenômenos de Path Dependence ${ }^{18}$ e Agency ${ }^{19}$ (JENSEN; MECKLING, 1976) costumam influenciar esse processo, pois determinam a forma como os agentes se relacionam, sob os mesmos pressupostos comportamentais da ECT de Williamson, estabelecendo o nível de cooperação entre as organizações em determinado mercado.

\subsubsection{Instituições Privadas}

Brousseau (2006) sugere que o ambiente institucional seja analisado sob uma ótica multinível. O autor se propõe a acrescentar à estrutura de pensamento elaborada por North um novo ângulo de visão, em que a mudança institucional ocorre com o surgimento de novas instituições privadas cujo nível de formalidade intrínseco seja diferente da instituição original.

\footnotetext{
${ }^{18}$ Refere-se ao condicionamento do desenvolvimento de determinados processos à sua configuração inicial.

19 A teoria de Agente-Principal é um constructo cujo agente toma decisões para o principal, sendo que o principal não tem informação plena sob tal tomada de decisão.
} 
Brousseau (2006) compartilha das idéias de North (1990; 1994a; 1994b) quanto a influência do ambiente institucional sobre a coordenação das transações, e de que a chave para esse efeito está na definição e proteção dos direitos de propriedade. Brousseau propõe que o ambiente institucional, tratado uniformemente por North, deveria ser dividido em dois subgrupos para análise. Tal divisão formaria o grupo das instituições privadas e o grupo das instituições genéricas.

Instituições genéricas são aquelas impostas aos agentes de forma mandatória, sem deixar opção de escolha e sem permitir negociações quanto ao seu conteúdo. Geralmente, tal conteúdo é pouco específico. Nesse grupo se encontram as leis impostas pelo Estado, e algumas convenções culturais não negociáveis, como por exemplo, a linguagem.

Instituições privadas são aquelas cuja adesão é voluntária e existe espaço para a negociação de seu conteúdo, o qual é bem mais específico que o das instituições genéricas. Nesse grupo se encaixam estruturas como, por exemplo, clubes, associações de classe e códigos de autoregulação.

Tanto as instituições privadas como as genéricas são coletivas, influenciando um grupo de indivíduos ao mesmo tempo. As instituições genéricas são destinadas a grandes grupos, enquanto as privadas, geralmente, influenciam grupos menores.

Seguindo a classificação de Brousseau (2006), a coordenação das transações passaria a ser analisada a partir de três níveis, ou seja, as instituições genéricas, as instituições privadas e os arranjos institucionais (arranjos contratuais bilaterais). $\mathrm{O}$ autor considera que as instituições genéricas apontadas por ele remetem ao conceito de ambiente institucional proposto por North (1990), sendo assim, Brousseau estaria incluindo o nível intermediário das instituições privadas na estrutura de análise, que, na proposta de North, só contava com o ambiente institucional e os arranjos contratuais bilaterais.

Para Brousseau (2006), o surgimento e a adoção das instituições privadas ocorrem quando a estrutura de coordenação oferecida pelas instituições genéricas somadas aos contratos bilaterais não são capazes de suprir as necessidades dos agentes ou são muito caras. Instituições privadas são a opção quando é mais barato e mais eficiente esse tipo de ação 
coletiva do que apenas contar com instituições genéricas e seus problemas de mal-adaptação, ou com arranjos institucionais e seus problemas de custo.

O modelo proposto por Brousseau (2006) admite que os agentes irão usar os três níveis de coordenação da forma que maximize seus benefícios. Eles poderão, inclusive, compor o uso das três estruturas ao mesmo tempo, equilibrando as falhas de uma com as capacidades de outra, se isso lhes oferecer vantagem.

Tendo concluído a revisão do aporte teórico da Nova Economia Institucional, será apresentado no próximo capítulo o modelo de avaliação contratual de Bogetoft e Olesen (2004), que se propõe a analisar detalhadamente a opção de contratos como estrutura de governança sob a ótica da NEI. 


\section{TEORIA DOS CONTRATOS: UMA ABORDAGEM HOLÍSTICA}

Bogetoft e Olesen (2004) propõem uma análise contratual ampla. Nas palavras dos autores: holística. Eles pretendem alcançar tal amplitude de duas formas: indicando um aporte teórico adequado e considerando todos os fatores necessários capazes de influenciar tal análise.

O aporte teórico adequado para discutir a economia dos contratos é, para os autores, uma composição das teorias de Agente-Principal e dos Custos de Transação. Essa composição, em uma mesma estrutura de análise, seria capaz de captar tanto questões ligadas à motivação dos agentes a partir das teorias de Agente-Principal (JENSEN; MECKLING, 1976), sendo consideradas, primordialmente, as implicações da Seleção Adversa (AKERLOFF, 1970) e do Moral Hazard ${ }^{20}$ (ARROW, 1984), como questões de coordenação a partir da teoria dos Custos de Transação (WILLIAMSON, 1985; 1996).

O segundo ponto defendido por Bogetoft e Olesen (2004) é de que se deve levar em conta um leque de fatores suficiente para compor uma análise contratual realista. Os autores criticam as teorias de contratos que hipertrofiam a análise de um determinado fator sem avaliar o contexto contratual por inteiro, incorrendo no risco de deixar de lado questões relevantes.

A análise holística tem como objetivo identificar o contrato que tenha o lucro integrado máximo, ou seja, a soma máxima do lucro das partes envolvidas. Para tanto, a análise contratual deve levar em consideração todos os fatores que compõem o contratado e também como cada fator (ou objetivo específico) influencia o desempenho de outro fator em um mesmo contrato (abordagem sistêmica).

Bogetoft e Olesen (2004) valorizam o estudo de contratos que estão em vigor, ou seja, valorizam a aplicabilidade prática da teoria. Sua proposta compreende tanto uma abordagem positiva quanto normativa. Positiva, enquanto se preocupa em descrever os fenômenos tentando apontar os motivos que sustentam sua ocorrência, e, normativa, enquanto abre espaço para discutir como um contrato deveria ser desenhado para coordenar uma determinada transação obtendo lucro integrado máximo.

\footnotetext{
${ }^{20}$ Ver notas 13 e 14
} 
A Figura 2 apresentada a seguir, ilustra uma situação hipotética em que um contrato ótimo é a estrutura de governança que gera o lucro integrado máximo para determinada transação, de acordo com o modelo de Bogetoft e Olesen.

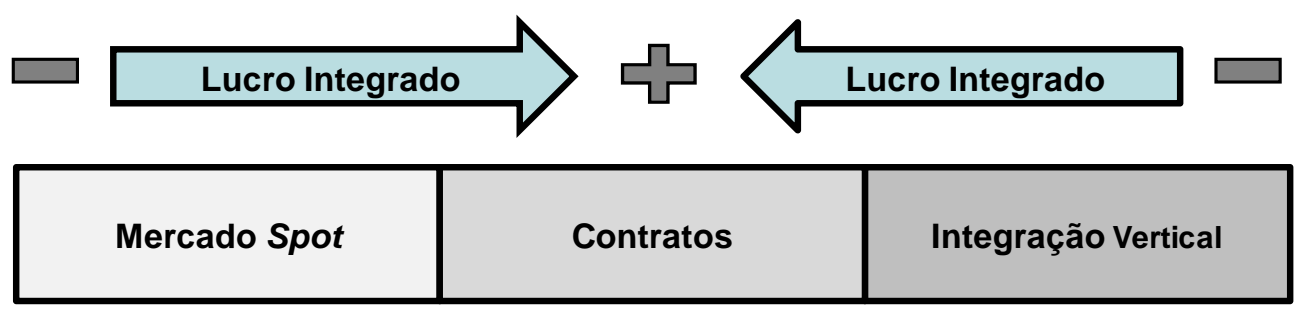

Figura 2: Lucro integrado máximo

FONTE: Elaborado pelo autor

O objetivo principal do contrato, o lucro integrado, é dividido em três objetivos básicos pelos autores: motivação, coordenação e custos de transação, como mostra a Figura 3. A seguir, cada um deles será discutido.

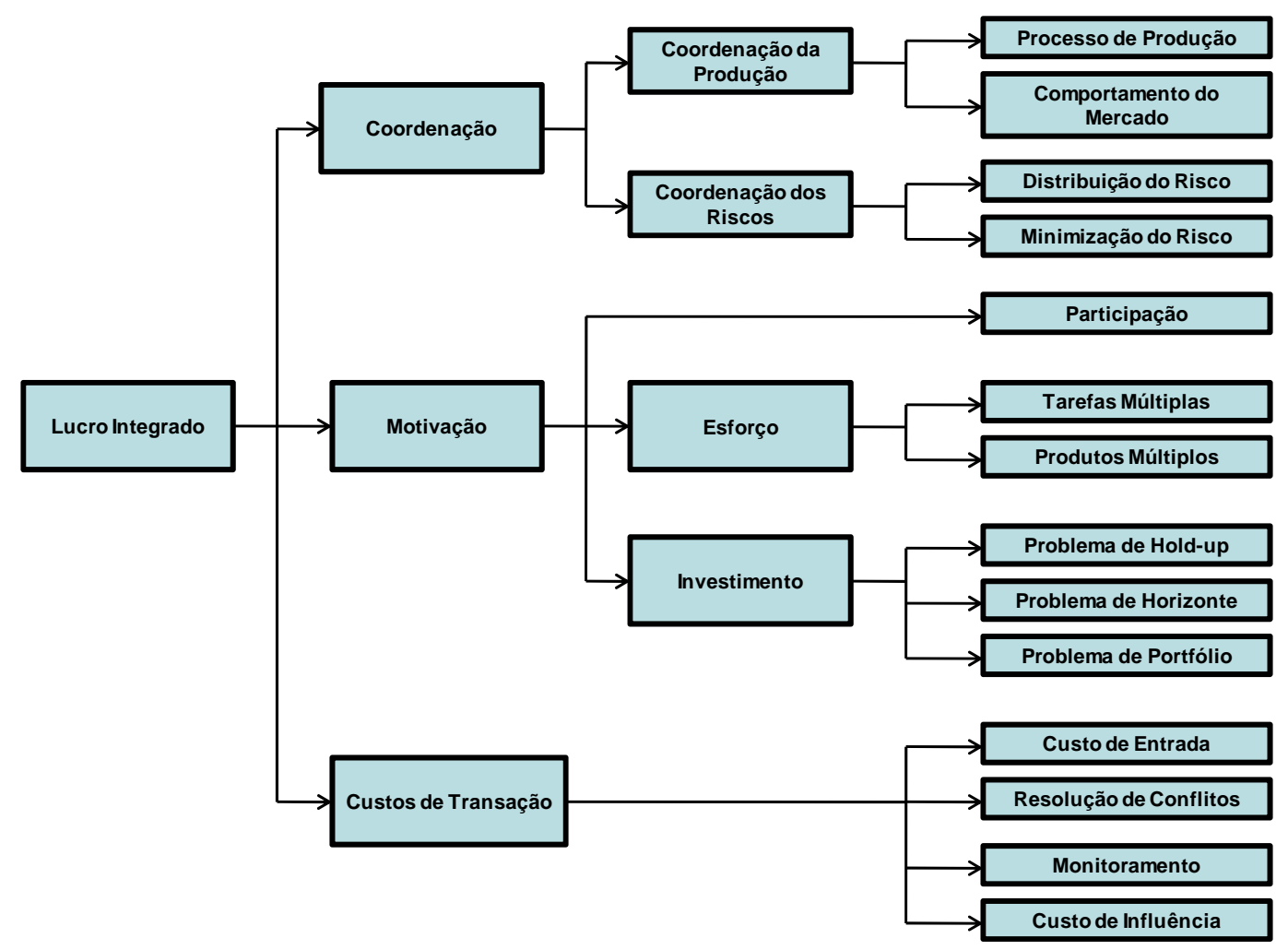

Figura 3: Hierarquia de objetivos para o desenho contratual FONTE: Bogetoft e Olesen (2004, p.47) 


\subsection{Coordenação}

O comportamento dos agentes envolvidos num contrato deve ser coordenado para garantir que os produtos ou serviços transacionados sejam produzidos na forma, qualidade, quantidade, lugar e tempo corretos. A coordenação ótima, de acordo com Bogetoft e Olesen (2004), é aquela capaz de articular a produção ao menor custo possível, correndo o menor risco possível.

A seguir, serão discutidas em separado a coordenação da produção e a coordenação do risco.

\subsubsection{Coordenação da produção}

A coordenação da produção é dividida pelos autores em: coordenação do processo produtivo e coordenação do comportamento de mercado na cadeia.

\subsubsection{Coordenação do processo produtivo}

As distintas estruturas de governança adotam maneiras diferentes de distribuir direitos de decisão entre seus componentes. A governança hierárquica tem o processo decisório centralizado e o mercado mantém os direitos de decisão amplamente distribuídos entre os agentes.

Os contratos carregam um nível intermediário de centralização das decisões, agregando elementos hierárquicos e de mercado, sendo por isso denominados também por formas híbridas $^{21}$ (MÉNARD, 2004). Dependendo da ocasião, os contratos podem lançar mão tanto do mecanismo de preços como de instrução.

Quando se decide o grau ideal de centralização do processo decisório a ser recomendado em um contrato, deve-se levar em conta a influência da centralização sobre o custo de informação. Sistemas centralizados têm um custo maior para obter a informação de que necessitam (MILGROM; ROBERTS, 1992).

\footnotetext{
${ }^{21}$ Existe uma descrição completa sobre a questão de formas híbridas no capítulo 2, sessão 2.2.2.
} 
Influenciando o custo de se obter informação, o grau de centralização terá um efeito direto sobre a ocorrência de comportamento oportunista, pois fica mais caro impedir que alguns agentes detenham informações privilegiadas (MILGROM; ROBERTS, 1992).

\subsubsection{Coordenação do comportamento de mercado na cadeia}

Quando a produção é descentralizada, o contrato deverá procurar alinhar o interesse individual dos agentes ao interesse do grupo. A escolha da quantidade ótima a ser produzida por cada indivíduo, e, em cada nível da cadeia, é um dos pontos a ser considerado como de possível conflito.

Se os agentes detêm algum poder de mercado, eles tenderão a escolher um nível de produção próprio que traga lucro máximo para si. Esse nível de produção pode não corresponder ao desejado para que os agentes envolvidos na transação alcancem o lucro integrado máximo ${ }^{22}$. Cabe ao contrato alinhar (coordenar) a escolha dos níveis de produção em prol da obtenção do lucro integrado máximo.

\subsubsection{Coordenação do risco}

A coordenação do risco compreende dois aspectos diferentes. O primeiro deles é a forma como o risco é alocado na cadeia de produção (Risk Sharing). O segundo é a possibilidade do contrato influenciar a quantidade de risco total tomado na cadeia (Risk Minimizing).

A alocação do risco, risk sharing, é determinada a partir do desenho contratual. Esta alocação será ideal quando minimizar o custo envolvido neste processo, ou seja, minimizar o custo que os agentes incorrem por aceitar determinado risco. Os agentes têm diferentes graus de aversão ao risco, sendo mais custoso alocar o risco de uma transação ao agente cujo grau de aversão ao risco for maior.

A distribuição (alocação) ótima de risco num contrato pode ser conduzida tanto entre as partes, como entre os vários componentes de uma mesma parte (quando uma parte é formada por um grupo de agentes independentes).

\footnotetext{
${ }^{22}$ Se, por exemplo, os fornecedores em um contrato estiverem recebendo um preço que lhes traz lucro máximo ao manter baixos níveis de produção, enquanto sua contraparte precisa, imprescindivelmente (como por exemplo, para manter a escala ideal em determinado processo industrial), de que todos os fornecedores produzam o máximo que podem, surge um conflito de interesses.
} 
Bogetoft e Olesen (2004) consideram importante o trade-off entre a minimização dos custos obtidos com a alocação de risco e os gastos com motivação, quando se avalia tal escolha. À medida que o agente mais avesso ao risco fica livre de tal pressão, surge espaço para comportamento oportunista ${ }^{23}$. Em conseqüência disso, deve-se observar a necessidade de oferecer incentivos motivacionais para manter tal agente fiel ao contrato.

A distribuição do risco, Risk Sharing, é uma questão que toma como dado o risco total incorrido pelos agentes. O contrato também pode influenciar a quantidade total de risco na cadeia, independente da forma de distribuição do risco entre os agentes, o que é classificado pelos autores como Risk Minimizing.

\subsection{Motivação}

De forma geral, a motivação é um dos mecanismos capaz de fazer com que tomadores de decisão independentes se alinhem num objetivo comum, ou seja, uma das funções principais dos contratos.

Os autores apontam três situações em que a motivação apresentada pelo desenho contratual será determinante ao sucesso de um contrato: a motivação à participação, a motivação ao esforço e a motivação ao investimento. Observando essas três situações, um contrato estará equacionando todo contexto motivacional.

\subsubsection{Participação}

A adesão ou não a um contrato irá depender da utilidade que tal ação confere às partes interessadas. Para que um contrato seja capaz de garantir a participação dos agentes econômicos, ele deve oferecer uma utilidade que seja ao menos igual à utilidade reserva dos mesmos.

Cada parte, ou agente, tem sua curva de utilidade própria e tais características individuais têm de ser contempladas na composição de um contrato.

\footnotetext{
${ }^{23}$ Nesse caso, sendo o comportamento oportunista pós contratual, Bogetoft e Olesen estão se referindo ao fenômeno de Moral Hazard.
} 
Bogetoft e Olesen (2004) frisam que uma situação propícia à ocorrência de oportunismo é aquela na qual os agentes, ou apenas um deles, não têm a informação completa sobre a utilidade reserva de suas contrapartes ${ }^{24}$. Nesses casos, poderá ocorrer captura de renda ${ }^{25}$ pela parte detentora de informação privilegiada sobre a outra.

\subsubsection{Esforço}

O conceito de esforço, traduzido do termo inglês: effort, utilizado por Bogetoft e Olesen (2004), indica a motivação dos agentes em cumprir o acordo firmado, ou seja, a motivação em permanecer fiel ao combinado. Para os autores, enquanto os agentes estiverem maximizando seu auto-interesse individual ao cumprirem o contrato, a fidelidade estará garantida.

O contrato pode lançar mão de ferramentas capazes de manter o auto-interesse dos indivíduos alinhado ao do contrato. Essas ferramentas são o monitoramento e os mecanismos de recompensa e punição, sendo que os últimos formam a matriz de incentivos do contrato.

O melhor uso dos incentivos se dá quando sua premiação (ou punição) está relacionada a parâmetros que revelam com precisão o esforço desempenhado pelo agente. Os autores se preocupam em apontar a importância de se excluir a interferência das incertezas da transação quando se avalia o esforço do agente ${ }^{26}$. Tal posição, de optar sempre pela forma mais precisa de qualificar e quantificar o esforço do agente é denominada pelos autores de Princípio da Informatividade (Informativeness Principle). Nesse sentido, quanto mais precisa for a avaliação do esforço, mais eficiente será o incentivo.

Se, por exemplo, um incentivo for vinculado diretamente ao volume de etanol entregue por uma usina em um contrato de fornecimento, corre-se o risco de que a incerteza climática possa influenciar a premiação de maneira adversa. Em uma safra com péssimas condições climáticas, o volume entregue será baixo, o que não irá refletir o esforço em cumprir o contrato por parte da usina.

\footnotetext{
${ }^{24}$ Nesse caso, sendo o comportamento oportunista pré contratual, Bogetoft e Olesen estão se referindo ao fenômeno de Seleção Adversa.

${ }^{25}$ Nesse caso, a renda capturada recebe o nome de renda informacional (Infomation Rent).

${ }^{26}$ A ocorrência, ou não, de monitoramento também influencia a precisão da avaliação do esforço.
} 
Quando o agente é um conjunto de indivíduos (Multiple Producers), pode-se evitar a contaminação por incerteza na avaliação do esforço usando-se a performance relativa ao grupo de cada indivíduo, como indicativo de seu esforço.

Os autores indicam a questão da multiplicidade de objetivos do agente (Multi-Tasking) como um ponto relevante na consideração da matriz de incentivos de um contrato. Se o Agente tem múltiplas tarefas, ele irá focar seu esforço nas mais rentáveis, sendo que o principal deve se antecipar a isso oferecendo uma matriz de incentivos capaz de direcionar o esforço do agente de forma balanceada.

Bogetoft e Olesen (2004) indicam quatro situações em que é atrativo ao principal manter forte a intensidade dos incentivos frente a uma expectativa de obter uma boa resposta quanto ao esforço do agente:

- Quanto maior o lucro incremental gerado pelo incentivo.

- Quanto mais tolerante ao risco for o agente. Esta situação remete ao trade-off discutido na seção 3.1.2: se o agente é tolerante ao risco, o custo em sua alocação de risco é baixo, sendo cabíveis maiores gastos com incentivos.

- Quanto mais precisa for a avaliação do esforço do agente (Informativeness Principle).

- Quanto maior for a sensibilidade de resposta a incentivos do agente.

\subsubsection{Investimento}

Necessidades de investimento são itens comumente abordados em contratos. Bogetoft e Olesen (2004) apontam três condições problemáticas que devem ser observadas para que um contrato tenha sucesso quando tratar de investimentos a serem feitos pelas partes 
A primeira questão é o problema do hold-up ${ }^{27}$. Sempre que houver investimento em algum ativo específico ${ }^{28}$, existe risco de hold-up. Nesse caso, o contrato deverá apresentar uma garantia mínima ao investidor de que ele não terá sua renda expropriada.

A segunda questão é o horizonte do contrato (Horizon Problem). Qualquer investimento só deverá ser feito se houver tempo hábil para seu retorno. Nesse sentido, o ciclo temporal ${ }^{29}$ de cada negócio deverá ser respeitado no desenho contratual para garantir o retorno dos investimentos.

A terceira e última questão é o problema de portfólio (Portfolio Problem). Todo novo investimento feito por um agente irá influenciar o nível médio de risco assumido por ele, pois esse novo investimento passará a fazer parte de seu portfólio de investimentos. Um contrato será bem sucedido se estiver alinhando o risco médio tomado pelo agente ao seu grau de aversão ao risco.

\subsection{Custos de transação}

Bogetoft e Olesen (2004) indicam a possibilidade de economizar custos de transação ${ }^{30}$ como o terceiro e último objetivo básico dos contratos. Na estrutura de análise proposta pelos autores, custos de transação são os custos de coordenar e motivar os agentes e, a título de análise, serão agrupados em quatro grupos: os custos de adotar (entrada) um contrato, os custo de resolver conflitos, custos de monitoramento e os custos para influenciar a contraparte.

\footnotetext{
${ }^{27}$ A presença de um ativo específico numa transação levará ao surgimento de uma quase-renda, que poderá ser expropriada do detentor de tal ativo por sua contraparte (KLEIN; CRAWFORD; ALCHIAN, 1978). Tal situação é denominada hold-up.

${ }^{28}$ Uma definição completa de especificidade de ativo está no capítulo II, seção 2.2.1.

${ }^{29}$ Um exemplo dessa diferença temporal nos ciclos de investimento e retorno pode ser bem percebido quando se comparam os longos prazos do setor de geração de energia elétrica com os curtos prazos do setor de tecnologia da informação.

${ }^{30}$ Uma explicação mais completa sobre o conceito de custo de transação encontra-se disponível no capítulo 2, seção 2.1.
} 


\subsubsection{Custo de adoção ao contrato}

A adoção de um contrato é vista pelos autores como fonte de três custos distintos. O primeiro deles é o custo de prever as contingências ${ }^{31}$, o segundo é o custo de negociar até chegar a um acordo e o terceiro é o custo de formatar o acordo negociado dentro da linguagem jurídica.

\subsubsection{Resolução de conflitos}

A incompletude contratual abre espaço para o surgimento de conflitos e disputas sobre contingências não previstas no contrato. A resolução destes conflitos durante a vigência do contrato incorre em custos, custos de transação.

Uma forma de minimizar tais custos é incluir no contrato a indicação de um mecanismo de resolução de disputas, como por exemplo, as câmaras de arbitragem. Outro mecanismo de resolução de disputas é aquele na qual se dá o poder de decisão a uma das partes, para que essa arbitre sobre o conflito. Para que isso ocorra, é necessário haver confiança ${ }^{32}$ entre as partes.

\subsubsection{Monitoramento}

Como dito na seção 3.2.2, o monitoramento é uma das ferramentas utilizadas para garantir o esforço (effort) dos agentes no cumprimento do contrato. Bogetoft e Olesen (2004) consideram os custos diretos de monitoramento como custos de transação.

\subsubsection{Custo de influência}

Os autores indicam que os custos de tentar influenciar ativamente a contraparte, buscando garantir sua cooperação, também devem ser considerados como custos de transação.

A seguir, no capítulo 4, será apresentado um conjunto descritivo de informações específicas do setor alcooleiro, que, somadas ao aporte teórico da NEI e ao modelo de Bogetoft e

\footnotetext{
${ }^{31}$ Num mundo complexo, cuja racionalidade dos agentes é limitada e a disponibilidade da informação é assimétrica, é impossível prever todas as contingências num contrato, sendo assim, diz-se que os contratos são sempre incompletos. Quanto maior o esforço necessário para contingenciar um contrato, maior o custo de adesão.

${ }^{32}$ Questões relacionais como a confiança entre os agentes são determinantes da ocorrência de custos de transação (WILLIAMSON, 1993)
} 
Olesen (2004), encerram a etapa das informações referenciais deste trabalho, conforme o modelo de etapas do método científico de Richardson (1999). 


\section{A INDÚSTRIA DO ÁLCOOL ETÍLICO}

O álcool etílico, ou etanol, é produzido no Brasil por usinas e destilarias. Geralmente, esse produto é elaborado sob duas formas quanto a quantidade de água em sua composição: o Álcool Etílico Hidratado, contendo de 6,2\% a 7,4\% de água, e o Álcool Etílico Anidro, com apenas $0,7 \%^{33}$.

Existem quatro setores de mercado a que se destina o etanol, como ilustra a Figura 4:

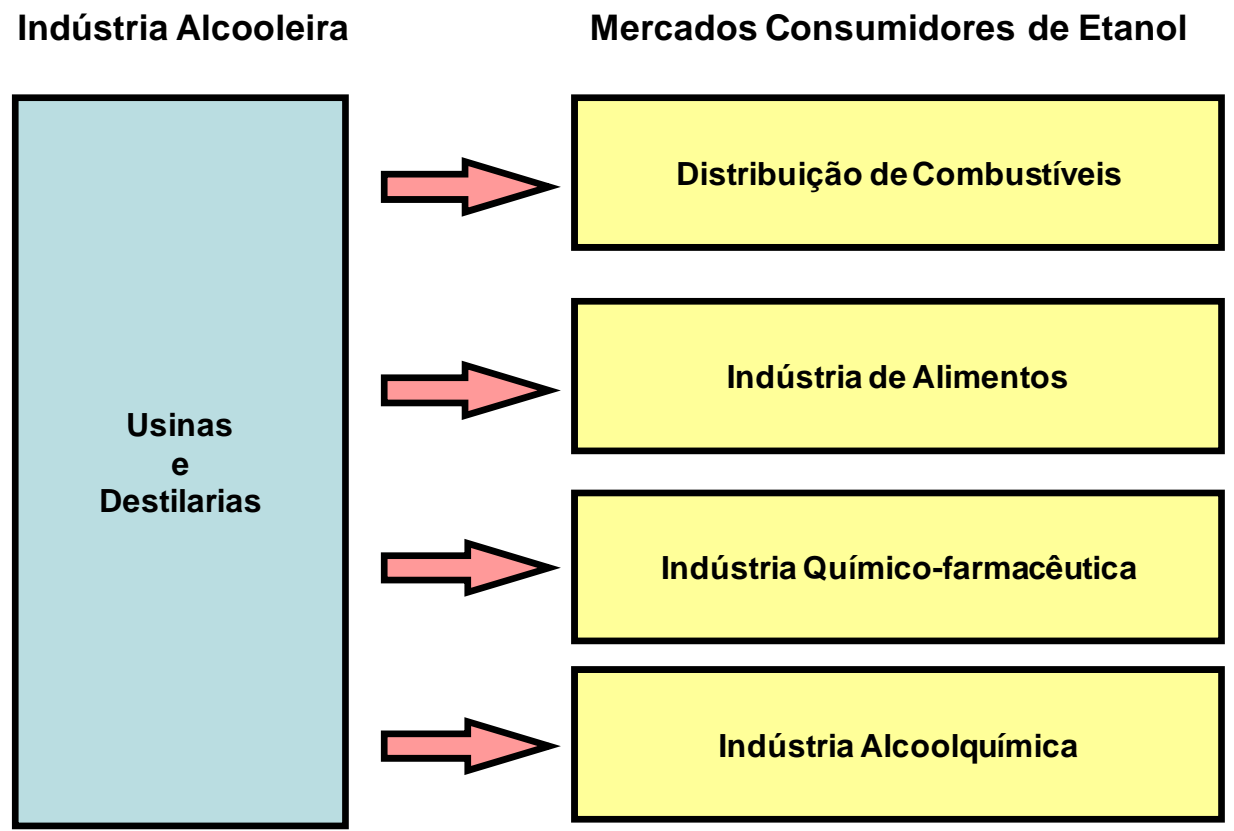

Figura 4: $O$ subsistema do álcool étílico

FONTE: Elaborado pelo autor com dados da Unica e MAPA.

A Distribuição de Combustíveis é o maior mercado consumidor de etanol. Neste setor, que será analisado detalhadamente mais a diante, a nomenclatura para estes dois tipos de alcoóis descritos anteriormente, recebe também o sufixo carburante, sendo geralmente denominados a partir de suas siglas: Álcool Etílico Anidro Carburante (AEAC) e Álcool Etílico Hidratado Carburante (AEHC).

A Indústria de Alimentos é o segundo maior mercado para o etanol. É neste mercado que se encontra a cachaça, aguardente tradicional brasileira, e maior representante em volume dos

\footnotetext{
${ }^{33}$ Resolução ANP nº 36, de 6 de dezembro de 2005.
} 
produtos alimentícios que recebem etanol. De acordo com a Conab, 10,5\% de toda a cana colhida no país na safra 2006/07 foi destinada à produção de cachaça (CONAB, 2006).

A Indústria Químico-farmacêutica também é consumidora de álcool etílico. Neste segmento temos vários casos conhecidos, como o próprio “álcool de limpeza”, tão comumente consumido nos lares brasileiros. Dentre as indústrias farmacêuticas, que usam geralmente etanol em suas formulações, a Indústria Cosmética é a mais importante, sendo este álcool o produto usado como veículo na fabricação de perfumes.

O etanol é o insumo principal da Indústria Alcoolquímica. Este ramo industrial tem como objetivo sintetizar polímeros complexos, também chamados "plásticos”, a partir do etanol como matéria-prima. Apesar da alcoolquímica ainda ser uma indústria incipiente, tanto no Brasil como no resto do mundo, sua importância é enorme, devido ao grande potencial de mercado para polímeros sintéticos feitos sem a utilização de petróleo.

Baseados na expectativa de que a alcoolquímica passe a ser viável economicamente ${ }^{34}$, em 2007, o Grupo Sucroalcooleiro Crystalsev e a Multinacional Dow Chemical, anunciaram o início de uma Joint Venture, com investimentos previstos em até 2 bilhões de dólares, para a formação de um Pólo Alcoolquímico no Brasil (COSTA, 2007). Também em 2007, a Oxiteno, braço químico do Grupo Odebrecht, anunciou projeto de montar uma biorrefinaria em Comendador Gomes, no triângulo mineiro, para produzir especialidades químicas a partir de álcool de cana (SCARAMUZZO; VIEIRA, 2007).

A seguir, serão apresentadas quatro seções dedicadas exclusivamente à Distribuição de Combustíveis, tema deste estudo. A primeira discute a cadeia de suprimentos do etanol de modo geral. As três seções seguintes focam especificamente as características da oferta de etanol oferecida pelas usinas, as características da demanda por este produto exercida pelas distribuidoras e, por fim, discute o ambiente institucional que envolve a comercialização do etanol.

\footnotetext{
${ }^{34}$ A produção de polímeros plásticos a partir do etanol é viável tecnicamente, porém não é competitiva frente ao processo que usa petróleo como matéria-prima.
} 


\subsection{O subsistema do etanol carburante}

O etanol carburante é o principal produto derivado da industrialização da cana, sem contar o açúcar.

A Figura 5 mostra os agentes e transações que participam e compõem o subsistema do etanol carburante, chamado daqui em diante como subsistema agroindustrial (SubSAG) do etanol carburante.

Petrobras
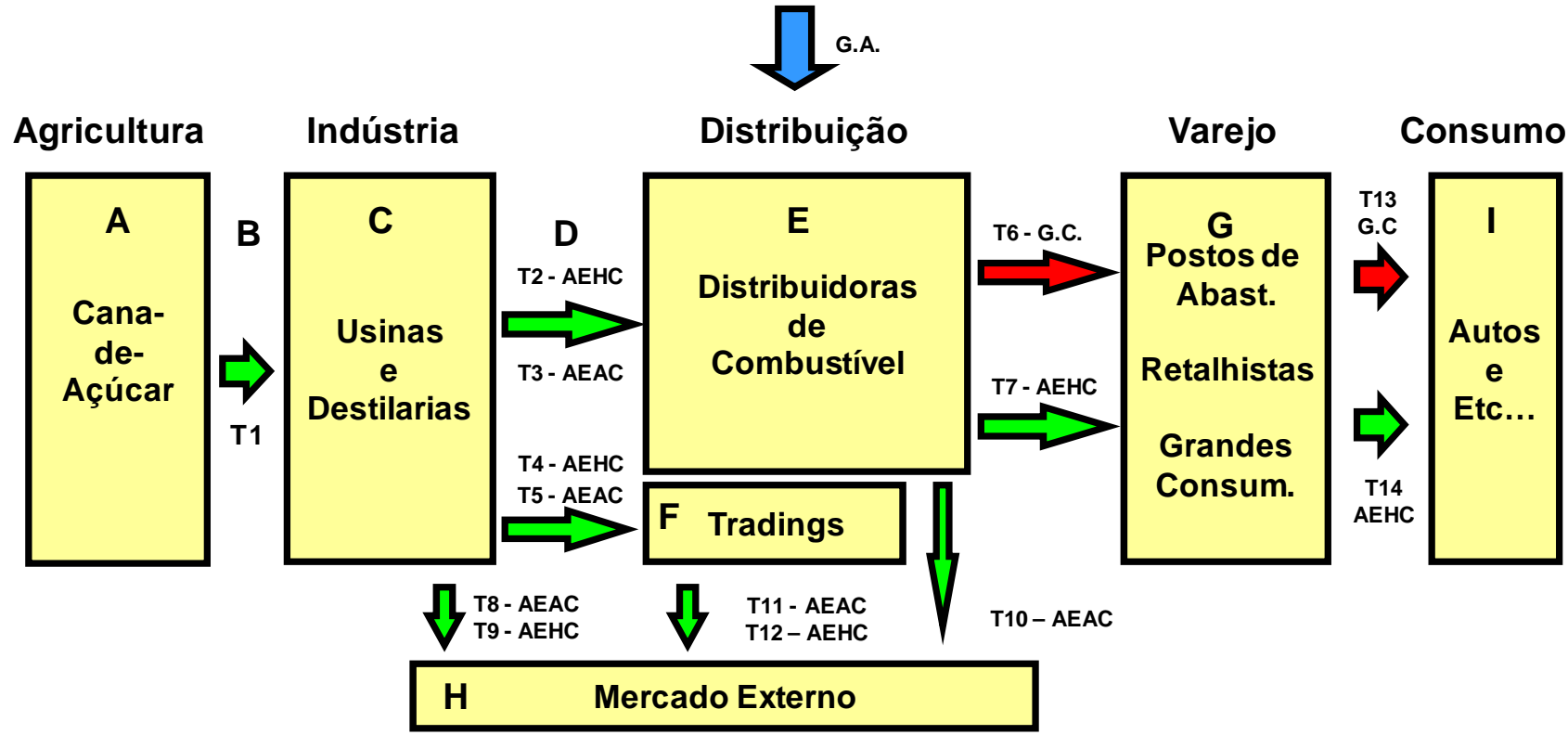

G.A. : Gasolina A AEAC: Álcool Etílico Anidro Carburante

G.C.: Gasolina C AEHC: Álcool Etílico Hidratado Carburante

Figura 5: $O$ subsistema do etanol carburante

FONTE: Elaborado pelo autor com dados da: Unica, MAPA, Sindicom, MME e SCA

Para abordar este subsistema produtivo, o texto a seguir está dividido em três partes: a primeira delas refere-se à produção industrial e agrícola, a segunda trata da distribuição no atacado e no varejo e a terceira discute a exportação do etanol 


\subsubsection{Produção agrícola e industrial}

A produção do etanol é feita em grandes plantas industriais. Uma parte destas fábricas é dedicada única e exclusivamente à produção de etanol e são chamadas de destilarias A maioria delas é também capaz de produzir açúcar, sendo denominadas usinas com destilarias anexas $^{35}$. De acordo com o Ministério da Agricultura, Pecuária e Abastecimento (MAPA), existem no Brasil 240 usinas, 106 destilarias e 15 unidades que produzem unicamente açúcar, totalizando 361 plantas industriais (MAPA, 2007a). São Paulo é o estado que possui o maior número de usinas do País. Estes dados indicam apenas as unidades efetivamente em atividade no ano de 2007.

As usinas, representadas na Figura 5 pelo Agente C, estão sempre localizadas junto às plantações de cana, uma vez que o custo de transporte da cana à usina é muito alto e, depois de colhida, a cana precisa ser processada em até 48hs para evitar sua degradação natural (MORAES, 1999 e WAAK et al. 1998).

Além de ter canavial próprio, as usinas também adquirem cana de produtores rurais estabelecidos próximos à elas, representados pelo Agente A na Figura 5. Em alguns casos, um agente intermediário, representado pelo Agente B na mesma figura, coordena o fornecimento de cana de um grupo de produtores à usina (PEDROSO Jr., 2008).

O principal destino do etanol, hidratado e anidro, produzido pelas usinas e destilarias, são as distribuidoras de combustíveis, como indicam as Transações T2 e T3, respectivamente, na Figura 5. Algumas usinas se organizam em grupos de comercialização, também chamados de pools de comercialização, para vender seus produtos às distribuidoras, outras vendem diretamente e independentemente. Os grupos de comercialização estão representados na Figura 5 pelo Agente D e serão discutidos em detalhes na seção 4.2.

\subsubsection{Distribuição: atacado e varejo}

Para produzir a gasolina C, aquela comercializada pelos postos de abastecimento no mercado de varejo, as distribuidoras fazem uma mistura de gasolina $\mathrm{A}$, isenta de etanol, fornecida às distribuidoras pela Petrobras, com o etanol anidro adquirido das usinas. A formulação dessa mistura, que determina a composição da gasolina C, é regulada pelo Governo Federal através

\footnotetext{
${ }^{35}$ Neste texto, será usado o termo simples “usina” para se referir às “usinas com destilaria anexa” e “destilarias”
} 
da ANP, Agência Nacional do Petróleo, Gás e Biocombustíveis, sendo que o etanol deve perfazer um mínimo de $20 \%$ e um máximo de $25 \%$ da mistura. A gasolina C, depois de preparada, é vendida aos postos de abastecimento, como indica a Transação T6, na Figura 5, onde os postos são representados pelo Agente G.

O etanol hidratado adquirido pelas distribuidoras é revendido aos postos de abastecimento sem sofrer qualquer alteração. Essa transação é indicada na Figura 5 como T7.

Entre as distribuidoras que operam no Brasil, destacam-se empresas como: BR (Petrobras), Shell, Chevron (Texaco), Esso (ExxonMobil) e outras. Detalhes sobre as distribuidoras serão apresentados na seção 4.3

Os postos de abastecimento podem estar vinculados a uma distribuidora, carregando sua marca sob contrato de fornecimento, ou não estarem ligados a qualquer distribuidora, sendo chamados: bandeira branca. A Tabela 1 mostra o número de postos de combustíveis no Brasil por grandes regiões. Percebe-se que uma porcentagem considerável, 39,1\%, dos postos são bandeira branca. A BR, distribuidora da Petrobras, é a distribuidora com maior número de postos, $19,0 \%$ do total. Ipiranga ${ }^{36}$ e Shell são a segunda e terceira colocadas, respectivamente, neste ranking, com $11,6 \%$ e $5,3 \%$ do total.

Tabela 1: Quantidade de postos de combustíveis, por bandeira, em 2005

\begin{tabular}{l|c|c|c|c|c|c|c|c|c}
\hline Grandes Regiões & Total & \multicolumn{1}{|c|}{ BR } & \multicolumn{2}{|c|}{ Ipiranga } & Shell & Chevron & Esso & $\begin{array}{c}\text { Bandeira } \\
\text { Branca }\end{array}$ & \begin{tabular}{c} 
Outras* \\
\hline Região Norte
\end{tabular} \\
\hline
\end{tabular}

*Inclui outras 126 bandeiras.

FONTE: Elaborado pelo autor com dados da ANP.

\footnotetext{
${ }^{36}$ Não levando em consideração que a operação de distribuição da Ipiranga nas regiões norte e nordeste foram adquiridas pela BR Distribuidora, em 2007.
} 
Além dos postos de abastecimento, existe outro agente que também está representado na Figura 5 pelo Agente G: o Transportador Revendedor Retalhista, o TRR. De acordo com o Sindicom $^{37}$ (SINDICOM, 2007b), existem 470 retalhistas em atividade no país, em 2007. Esses retalhistas, ainda de acordo com o Sindicom, são responsáveis por atender pequenas empresas consumidoras e produtores rurais, enquanto os postos de abastecimento atendem diretamente automobilistas e caminhoneiros. Vale ressaltar que alguns agentes podem adquirir combustível diretamente das distribuidoras, sendo classificados como Grandes Consumidores pelo Sindicom (2007b). Todos esses agentes, que formam a massa de consumidores finais, são representados na Figura 5 pelo Agente I.

\subsubsection{Exportação}

O mercado externo é abastecido pelos pools de comercialização, por usinas independentes e pelas trading companies, representadas pelo Agente F na Figura 5. A trading company não age apenas como uma articuladora, ela efetivamente adquire o produto para revendê-lo, como indicam as Transações T11 e T12, também na mesma figura. Existem casos em que a trading adquire o etanol por meio de um pool de comercialização.

Entre as trading companies que mais se destacam com atuação no Brasil, estão: Cargill, ED\&F Man, Coimex, Noble Group, Glencore, Archer Daniels Midland Company (ADM) e LDCommodities (Dreyfus).

${ }^{37}$ O Sindicom (Sindicato Nacional das Empresas Distribuidoras de Combustíveis e de Lubrificantes), entidade fundada em 1941, representa as seguintes companhias distribuidoras de combustíveis e de lubrificantes: AirBP, Ale, Castrol, Chevron, Esso, Ipiranga, Petrobras Distribuidora, Petronas Lubrificantes, Repsol e Shell. Suas associadas representam 81\% do volume de distribuição de combustíveis e lubrificantes no Brasil, em 2008. 
A Tabela 2 mostra o volume total ${ }^{38}$ exportado de etanol pelo Brasil e seus países de destino em 2006. Nota-se que, dos 3,4 bilhões de litros exportados, 52\% foi enviado aos Estados Unidos.

Tabela 2: Destino das exportações do etanol brasileiro em 2006

\begin{tabular}{l|c|c|c}
\hline Destino em 2006 & $\begin{array}{c}\text { Etanol- milhões de } \\
\text { litros }\end{array}$ & $\begin{array}{c}\text { Total acumulado em } \\
\text { porcentagem }\end{array}$ \\
\hline EUA & 1767 & $52 \%$ & $52 \%$ \\
\hline América Latina & 659 & $19 \%$ & $71 \%$ \\
\hline UE25 & 585 & $17 \%$ & $88 \%$ \\
\hline Japão & 225 & $7 \%$ & $94 \%$ \\
\hline Coréia & 92 & $3 \%$ & $97 \%$ \\
\hline Nigéria & 43 & $1 \%$ & $98 \%$ \\
\hline Índia & 10 & $0 \%$ & $99 \%$ \\
\hline Outros & 47 & $1 \%$ & $100 \%$ \\
\hline Total & 3428 & \\
\hline
\end{tabular}

FONTE: Elaborado pelo autor com dados do Secex.

No mercado externo, o etanol é adquirido principalmente por empresas distribuidoras de combustíveis como: Shell, Exxon, Chevron, representados pelo Agente H na Figura 5.

Um caso ímpar de destinação do etanol ao exterior é o caso da Shell. A empresa, que atua como distribuidora de combustíveis no Brasil e no resto do mundo, remete diretamente para si mesma o produto para distribuí-lo fora do país, como indica a Transação T10 na Figura 5.

Algumas Trading Companies também detêm a produção das commodities agrícolas que comercializam. Na cadeia sucroalcooleira, a Dreyfus, além de comercializar o etanol, produz este álcool a partir de três usinas próprias no Brasil. Nesse caso, a integração vertical ocorre desde o plantio da cana até a exportação do álcool.

Tendo apresentado o Sub-SAG do etanol carburante, as próximas duas seções, 4.2 e 4.3, darão destaque aos agentes efetivamente estudados neste trabalho, as usinas e distribuidoras de combustíveis, apresentando os agentes e suas participações no mercado, delimitando suas áreas de atuação e discutindo a estruturação de oferta e demanda nesta relação. Por fim, a

\footnotetext{
${ }^{38}$ Referente à soma de hidratado e anidro.
} 
seção 4.4 discute o ambiente institucional e organizacional que envolve a comercialização do etanol.

\subsection{As usinas e a estruturação da oferta}

Conforme comentado na seção anterior, existem 346 usinas ativas no Brasil. A Tabela 3 apresentada a seguir, evidencia as 20 maiores produtoras de etanol da região centro-sul na safra 2006/07, seus estados e municípios de ocorrência. A região centro-sul é formada pelas regiões sul, sudeste e centro-oeste.

Tabela 3: Maiores produtoras de etanol da região centro-sul

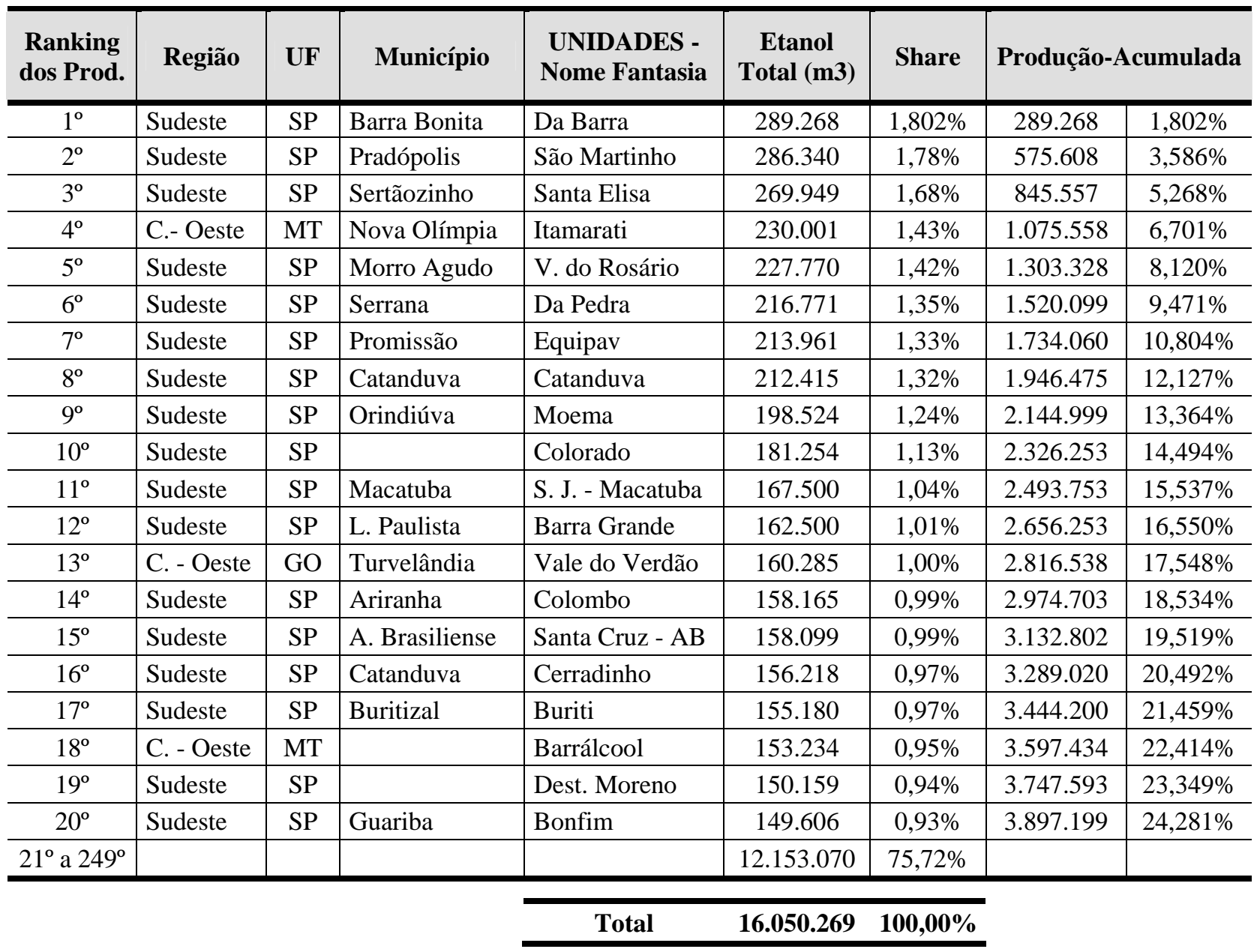

FONTE: Elaborado pelo autor com dados da UNICA, MAPA e UDOP.

Entre as maiores usinas produtoras de etanol estão: Da Barra, São Martinho, Santa Elisa e Vale do Rosário. Sendo que a maior delas, a Usina da Barra, produziu 289.268 $\mathrm{m}^{3}$ em uma safra que totalizou $16.050 .269 \mathrm{~m}^{3}$. Percentualmente, a produção da Usina da Barra 
corresponde a apenas 1,8 \% do total, indicando uma concentração baixa na produção de etanol com relação ao número de plantas industriais. Quanto à concentração, temos que o $\mathrm{CR}^{39}$ corresponde a apenas $8,1 \%$ e o CR10 a $14,5 \%$ do total da safra.

A Tabela 4 mostra a produção de etanol por estado brasileiro, confirmando a liderança do Estado de São Paulo, que é responsável por 68\% da produção do centro-sul, possuindo 148 usinas, o que corresponde a 59,44 \% do total de usinas da Região.

Tabela 4: Produção de etanol por estado na região centro-sul, safra 2006/07

\begin{tabular}{l|l|c|c|c|c|c}
\hline \multirow{2}{*}{ Região } & \multicolumn{1}{c|}{ Estado } & $\begin{array}{c}\text { Unidades } \\
\text { Cadastradas }\end{array}$ & $\begin{array}{c}\text { Unidades Ativas } \\
\text { na Produção de } \\
\text { Etanol }\end{array}$ & \multicolumn{2}{c}{$\begin{array}{c}\text { Produção de Etanol em } \\
\text { m3 }\end{array}$} \\
\hline Sudeste & São Paulo & 180 & 148 & $59,44 \%$ & 10.953 .937 & $68,25 \%$ \\
\hline Sul & Paraná & 28 & 27 & $10,84 \%$ & 1.318 .904 & $8,22 \%$ \\
\hline Sudeste & Minas Gerais & 43 & 23 & $9,24 \%$ & 1.291 .445 & $8,05 \%$ \\
\hline Centro-Oeste & Goiás & 24 & 15 & $6,02 \%$ & 821.556 & $5,12 \%$ \\
\hline Centro-Oeste & Mato Grosso & 16 & 12 & $4,82 \%$ & 757.251 & $4,72 \%$ \\
\hline Centro-Oeste & Mato G. do Sul & 12 & 10 & $4,02 \%$ & 640.843 & $3,99 \%$ \\
\hline Sudeste & Espírito Santo & 6 & 6 & $2,41 \%$ & 173.192 & $1,08 \%$ \\
\hline Sudeste & Rio de Janeiro & 16 & 7 & $2,81 \%$ & 87.455 & $0,54 \%$ \\
\hline Sul & Rio G. do Sul & 1 & 1 & $0,40 \%$ & 5.686 & $0,04 \%$ \\
\hline Sul & Santa Catarina & 1 & 0 & $0,00 \%$ & & $0,00 \%$ \\
\hline
\end{tabular}

FONTE: Elaborado pelo autor com dados da UNICA, MAPA e UDOP.

O Paraná é o segundo maior produtor, sendo responsável por 8,22\% do total da produção, e 10,84\% das unidades produtivas. Uma diferença bastante abrupta quando comparado a São Paulo. Minas Gerais ocupa o terceiro lugar, respondendo por 8,05\% da produção a partir de 23 unidades produtivas.

\footnotetext{
${ }^{39}$ Índice de Concentração das 5 maiores empresas do setor.
} 
É comum um grupo industrial contar com mais de uma usina. De acordo com a Tabela 5, pode-se observar os principais grupos, o número de usinas que cada um deles detém, assim como sua produção de etanol na safra 2006/07.

Tabela 5: Produção de etanol por grupo industrial na região centro-sul, safra 2006/07

\begin{tabular}{|c|c|c|c|c|c|c|c|c|}
\hline $\begin{array}{l}\text { Ranking da } \\
\text { Produção }\end{array}$ & Grupo - Usina & Região & UF & $\begin{array}{l}N^{0} \text { de } \\
\text { Unid. }\end{array}$ & $\begin{array}{c}\text { Etanol } \\
\text { Total (m3) }\end{array}$ & Share & \multicolumn{2}{|c|}{ Produção-Acumulada } \\
\hline $1^{\circ}$ & COSAN & Sudeste & SP & 15 & 1.265 .829 & $7,89 \%$ & 1.265 .829 & $7,89 \%$ \\
\hline $2^{\circ}$ & Santeliza Vale & Sudeste & SP & 5 & 700.260 & $4,36 \%$ & 1.966 .089 & $12,25 \%$ \\
\hline $3^{\circ}$ & Ir. Biagi - Pedra Agr. & Sudeste & SP & 3 & 426.320 & $2,66 \%$ & 2.392 .409 & $14,91 \%$ \\
\hline $4^{0}$ & Zilor & Sudeste & SP & 3 & 402.011 & $2,50 \%$ & 2.794 .420 & $17,41 \%$ \\
\hline $5^{\circ}$ & São Martinho & Sudeste & $\mathrm{SP}$ & 2 & 393.530 & $2,45 \%$ & 3.187 .950 & $19,86 \%$ \\
\hline $6^{\circ}$ & Moema & Sudeste & MG/SP & 3 & 333.264 & $2,08 \%$ & 3.521 .214 & $21,94 \%$ \\
\hline $7^{\circ}$ & Tereos & Sudeste & $\mathrm{SP}$ & 4 & 309.072 & $1,93 \%$ & 3.830 .286 & $23,86 \%$ \\
\hline $8^{\circ}$ & Virgolino Oliveira & Sudeste & SP & 3 & 305.283 & $1,90 \%$ & 4.135 .569 & $25,77 \%$ \\
\hline $9^{\circ}$ & Tércio Wanderley & Sudeste & MG & 3 & 267.848 & $1,67 \%$ & 4.403 .417 & $27,44 \%$ \\
\hline $10^{\circ}$ & USJ & Sudeste & $\mathrm{SP}$ & 2 & 265.379 & $1,65 \%$ & 4.668 .796 & $29,09 \%$ \\
\hline $11^{\circ}$ & Nova América & Sudeste & SP & 2 & 237.003 & $1,48 \%$ & 4.905 .799 & $30,57 \%$ \\
\hline $12^{\circ}$ & Itamarati & C. - Oeste & MT & 1 & 230.001 & $1,43 \%$ & 5.135 .800 & $32,00 \%$ \\
\hline $13^{\circ}$ & Equipav & Sudeste & SP & 1 & 213.961 & $1,33 \%$ & 5.349 .761 & $33,33 \%$ \\
\hline $14^{\circ}$ & Carlos Lyra & Sudeste & MG & 2 & 197.291 & $1,23 \%$ & 5.547 .052 & $34,56 \%$ \\
\hline $15^{\circ}$ & LDCommodities & Sudeste & MG/ SP & 3 & 184.287 & $1,15 \%$ & 5.731 .339 & $35,71 \%$ \\
\hline $16^{\circ}$ & Colorado & Sudeste & $\mathrm{SP}$ & 1 & 181.254 & $1,13 \%$ & 5.912 .593 & $36,84 \%$ \\
\hline $17^{\circ}$ & Vale do Verdão & C. - Oeste & $\mathrm{GO}$ & 1 & 160.285 & $1,00 \%$ & 6.072 .878 & $37,84 \%$ \\
\hline $18^{\circ}$ & João Lyra & Sudeste & MG & 2 & 158.274 & $0,99 \%$ & 6.231 .152 & $38,82 \%$ \\
\hline $19^{\circ}$ & Colombo & Sudeste & $\mathrm{SP}$ & 1 & 158.165 & $0,99 \%$ & 6.389 .317 & $39,81 \%$ \\
\hline $20^{\circ}$ & Balbo & Sudeste & SP & 2 & 156.517 & $0,98 \%$ & 6.545 .834 & $40,78 \%$ \\
\hline \multirow[t]{2}{*}{$21^{\circ}$ a $197^{\circ}$} & OUTROS & C. -Sul & N/A & 190 & 9.504 .435 & $59,22 \%$ & 16.050 .269 & $100,00 \%$ \\
\hline & \multicolumn{3}{|l|}{ TOTAL } & 249 & 16.050 .269 & $100,00 \%$ & 16.050 .269 & $100,00 \%$ \\
\hline
\end{tabular}

FONTE: Elaborado pelo autor com dados da UNICA, MAPA e UDOP.

A Cosan é o maior dos grupos, responsável por 15 unidades produtivas e uma produção de $1.265 .829 \mathrm{~m}^{3}$. Essa produção corresponde a 7,89\% de toda a produção do centro-sul e todas as suas 15 unidades estão no Estado de São Paulo.

O segundo maior, o Grupo Santeliza Vale, foi formado a partir da compra da Vale do Rosário pela Santa Elisa, em 2007 (CORREA, 2007). Sua produção foi de $700.260 \mathrm{~m}^{3}$, ou seja, 4,36\% do total. 
Entre os cinco maiores, também figuram os Grupos: Zilor, Pedra Industrial e São Martinho. Estes cinco primeiros detêm 19,86\% da produção total, com suas 28 usinas, todas elas no Estado de São Paulo.

Os dez primeiros grupos produzem $29,09 \%$ do total, o que novamente sugere uma baixa concentração da produção neste mercado. Sem contar os dois primeiros, nenhum outro grupo chega a produzir 3\% do total ou possuir mais de 4 unidades fabris.

\subsubsection{Os grupos de comercialização}

A comercialização do etanol conta com uma estruturação organizacional entre os produtores de etanol que vai além dos grupos industriais. Neste caso $^{40}$, os usineiros se organizam em grupos de comercialização.

No centro-sul, ocorrem 5 grupos de comercialização: Copersucar, Sociedade corretora de Álcool (SCA), Crystalsev, Bioagência e a CPA Trading.

\footnotetext{
${ }^{40}$ A motivação e a dinâmica que levam as usinas a se organizarem assim, serão discutidas no capítulo 7
} 
A Tabela 6 apresentada a seguir, traz dados referentes às unidades industriais e volume comercializado por estas organizações ${ }^{41}$.

Tabela 6: Pools de comercialização de etanol, na safra 2006/07

\begin{tabular}{|c|c|c|c|c|c|}
\hline $\begin{array}{c}\text { Canal de } \\
\text { Comercialização }\end{array}$ & Região & UF & Unidades & $\begin{array}{l}\text { Etanol Total } \\
\text { (m3) }\end{array}$ & Share \\
\hline Bioagência & Sudeste & MG & 2 & 197.291 & $1,23 \%$ \\
\hline Bioagência & Sul & $\mathrm{PR}$ & 2 & 143.858 & $0,90 \%$ \\
\hline Bioagência & Sudeste & SP & 12 & 755.045 & $4,70 \%$ \\
\hline \multicolumn{3}{|l|}{ Bioagência } & 16 & 1.096 .194 & $6,83 \%$ \\
\hline Copersucar & Sudeste & MG & 1 & 59.509 & $0,37 \%$ \\
\hline Copersucar & Sul & PR & 2 & 143.968 & $0,90 \%$ \\
\hline Copersucar & Sudeste & SP & 25 & 2.510 .246 & $15,64 \%$ \\
\hline \multicolumn{3}{|l|}{ Copersucar } & 28 & 2.713 .723 & $16,91 \%$ \\
\hline CPA Trading & Sudeste & MG & 1 & 40.378 & $0,25 \%$ \\
\hline CPA Trading & Sul & PR & 13 & 640.605 & $3,99 \%$ \\
\hline \multicolumn{3}{|l|}{ CPA Trading } & 14 & 680.983 & $4,24 \%$ \\
\hline \multicolumn{2}{|l|}{ Crystalsev } & SP & 9 & 1.148 .187 & $7,15 \%$ \\
\hline SCA & C. - Oeste & $\mathrm{GO}$ & 6 & 446.346 & $2,78 \%$ \\
\hline SCA & Sudeste & MG & 2 & 92.753 & $0,58 \%$ \\
\hline SCA & Sul & PR & 1 & 17.070 & $0,11 \%$ \\
\hline SCA & Sudeste & SP & 28 & 2.067 .695 & $12,88 \%$ \\
\hline \multicolumn{3}{|l|}{ SCA } & 37 & 2.623 .864 & $16,35 \%$ \\
\hline \multicolumn{3}{|l|}{ SCA + Crystalsev } & 46 & 3.772 .051 & $23,50 \%$ \\
\hline \multicolumn{3}{|l|}{ Total em Pool } & 104 & 8.262 .951 & $51,48 \%$ \\
\hline \multicolumn{3}{|l|}{ Unid. não organizadas } & 145 & 7.787.318 & $48,52 \%$ \\
\hline \multicolumn{3}{|l|}{ Total } & 249 & 16.050 .269 & $100,00 \%$ \\
\hline
\end{tabular}

FONTE: Elaborado pelo autor com dados da UNICA, MAPA, Copersucar, SCA, Bioagência, CPA Trading e Crystalsev

É notável que 51,48\% de todo álcool produzido no centro-sul é comercializado por meio dos pools.

A Copersucar, que também comercializa o açúcar de suas unidades, foi responsável pela comercialização de $2.713 .723 \mathrm{~m}^{3}$ de etanol na safra 2006/07, 16,91\% do total produzido, a

\footnotetext{
${ }^{41}$ Nesta tabela, o volume de vendas está sendo considerado o mesmo que o volume produzido pelas usinas. Foi considerando que todo o etanol produzido pela Crystalsev é comercializado pela SCA
} 
partir de 28 plantas industriais. Entre seus integrantes, destaca-se a presença de grupos como: Balbo, Ipiranga $^{42}$, Pedra Industrial, São Martinho ${ }^{43}$, Virgolino Oliveira e Zilor.

A Copersucar caracteriza-se por comercializar com exclusividade toda produção de suas cooperadas (MORI, 2007).

A SCA, Sociedade Corretora de Álcool, não detém a exclusividade da comercialização da produção de suas associadas (MORI, 2007; RODRIGUES, 2007). Na Tabela 6, o volume comercializado por ela, proveniente de 37 plantas industriais, alcança $2.623 .864 \mathrm{~m}^{3}, 16,35 \%$ do total comercializado na safra 2006/07 no centro-sul. Esse volume está bastante próximo da marca da Copersucar, mas deve ser entendido que os dados da tabela são, a rigor, da quantidade produzida, e não efetivamente do volume comercializado. Sendo assim, devemos esperar que, na prática, a SCA comercialize menos que o indicado nessa tabela, por não deter a exclusividade da comercialização de suas associadas.

A Cosan, maior grupo industrial do setor, é a principal associada da SCA. Além da Cosan, integram esse pool os grupos: Tereos (Guarani), Petribu, Albertina e a própria Crystalsev

A Crystalsev é uma empresa que foi criada por um grupo de usinas para comercializar seus produtos, tanto açúcar como etanol. Este grupo de comercialização opera de maneira ímpar, pois uma parte de seus produtos é comercializado pela SCA ${ }^{44}$. A Crystalsev foi responsável pela comercialização de $1.148 .187 \mathrm{~m}^{3}$ de etanol, 7,15\% do total comercializado no centro-sul. Dentre os integrantes da Crystalsev, destacam-se os grupos Santeliza Vale e Moema.

A Bioagência, representando 16 unidades, foi responsável pela comercialização de 6,86\% do etanol da safra 2006/07. Os grupos Carlos Lyra e Viralcool estão entre os integrantes deste pool.

O menor dos grupos de comercialização é a CPA Trading que atua principalmente na região sul, no Estado do Paraná. Entre seus integrantes, destaca-se o Grupo Santa Terezinha e o Grupo Vale do Ivai.

\footnotetext{
${ }^{42}$ Este Grupo não faz parte da Distribuidora Ipiranga

${ }^{43}$ O Grupo São Martinho anunciou seu desligamento da Copersucar em 2008.

${ }^{44}$ Detalhes sobre a organização da Crystalsev e de seu relacionamento com a SCA, assim como detalhes sobre os outros grupos de comercialização, serão apresentados no capítulo 7.
} 
Quando se considera a organização das usinas em grupos de comercialização, a estruturação destes agentes passa a ser bem mais concentrada que ao se observar apenas a concentração das plantas industriais e dos grupos industriais. Devido a isso, conclui-se que, na prática, devido à forma como se organiza a comercialização, as usinas estão estruturadas num oligopólio com franja competitiva ao ofertarem o etanol às distribuidoras.

Devido à sazonalidade da cana-de-açúcar, os preços do etanol costumam apresentar um comportamento típico no decorrer da safra. Em dezembro, fim da safra, e nos meses da entressafra: janeiro, fevereiro e março, os preços estão elevados. À medida que a produção se inicia, os preços começam a cair. Geralmente, o patamar mais baixo é alcançado entre maio, junho e julho, começando novamente a subir a partir daí, até o fim da safra (Bacchi, 2006).

O Gráfico 1 apresentado a seguir, ilustra o perfil dos preços do etanol, ao retratar suas variações, ao longo de 2005.

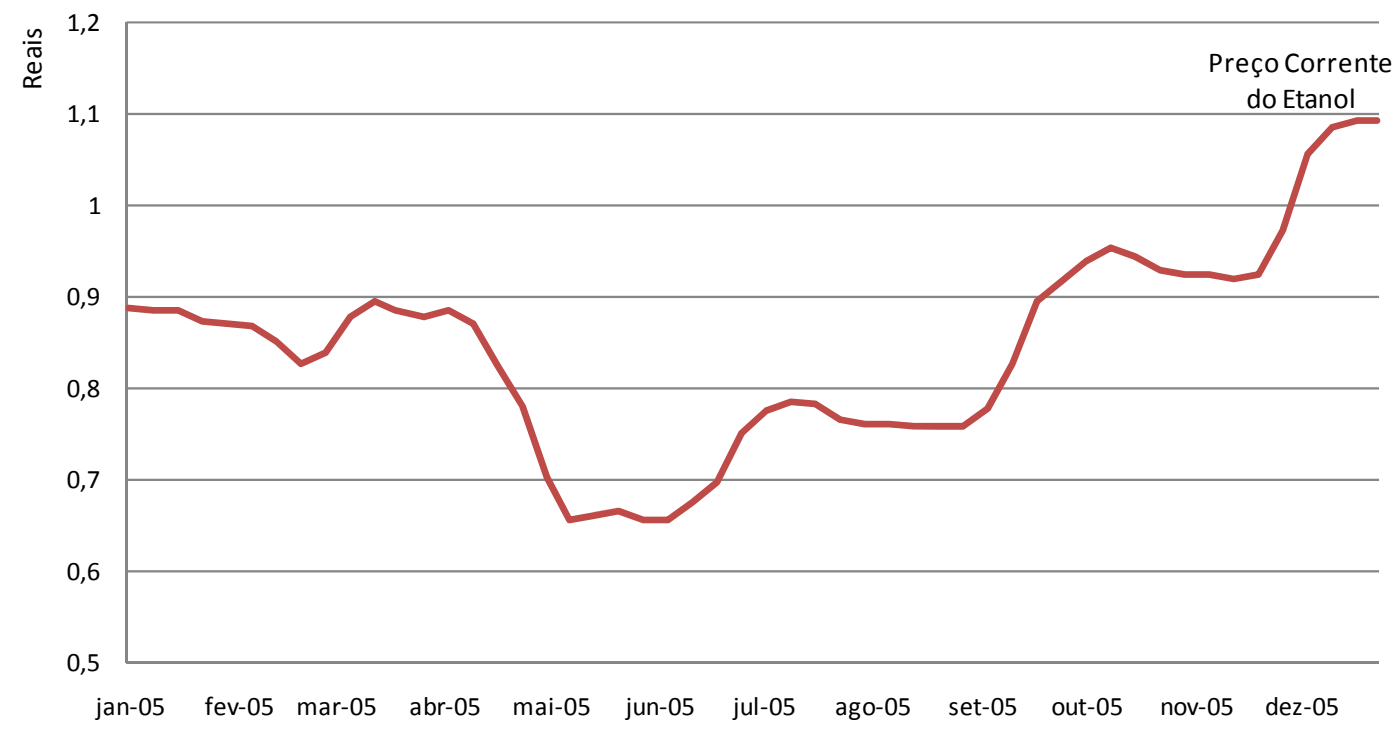

Gráfico 1: Perfil da variação do preço do etanol FONTE: Elacorado pelo Autor com dados do CEPEA 


\subsection{As distribuidoras e a estruturação da demanda}

No Brasil operam 164 distribuidoras de combustíveis. A Tabela 7 apresentada a seguir, evidencia as 20 maiores distribuidoras, tanto de gasolina $\mathrm{C}$ como de hidratado no ano de 2005.

Tabela 7: As vinte maiores distribuidoras de gasolina C e etanol hidratado do Brasil em 2005

\begin{tabular}{|c|c|c|c|c|c|c|c|}
\hline \multicolumn{2}{|c|}{$\begin{array}{l}\text { Distribuidoras de } \\
\text { Combustíveis }\end{array}$} & \multirow{2}{*}{$\begin{array}{c}\text { \% da Venda de } \\
\text { Hidratado em } \\
2005 \\
17 \%\end{array}$} & \multirow{2}{*}{$\begin{array}{c}\text { \% acumulado } \\
\text { da Venda de } \\
\text { Hidratado em } \\
2005 \\
17 \% \\
\end{array}$} & \multicolumn{2}{|c|}{$\begin{array}{l}\text { Distribuidoras de } \\
\text { Combustíveis }\end{array}$} & \multirow{2}{*}{$\begin{array}{c}\begin{array}{c}\text { \% da Venda } \\
\text { de Gasolina C } \\
\text { em } 2005\end{array} \\
24 \% \\
\end{array}$} & \multirow{2}{*}{$\begin{array}{c}\begin{array}{c}\% \text { Acumulado } \\
\text { da Venda de } \\
\text { Gasolina C em } \\
2005\end{array} \\
24 \% \\
\end{array}$} \\
\hline $1^{\circ}$ & $\mathrm{BR}$ & & & $1^{\circ}$ & $\mathrm{BR}$ & & \\
\hline $2^{\circ}$ & Ipiranga & $14 \%$ & $31 \%$ & $2^{\circ}$ & Ipiranga & $16 \%$ & $41 \%$ \\
\hline $3^{\circ}$ & Shell & $10 \%$ & $42 \%$ & $3^{\circ}$ & Shell & $10 \%$ & $51 \%$ \\
\hline $4^{\circ}$ & Chevron & $7 \%$ & $49 \%$ & $4^{\circ}$ & Esso & $9 \%$ & $60 \%$ \\
\hline $5^{\circ}$ & Esso & $5 \%$ & $54 \%$ & $5^{\circ}$ & Chevron & $9 \%$ & $69 \%$ \\
\hline $6^{\circ}$ & Tux & $4 \%$ & $58 \%$ & $6^{\circ}$ & Ale & $3 \%$ & $72 \%$ \\
\hline $7^{\circ}$ & Petronova & $4 \%$ & $62 \%$ & $7^{\circ}$ & Petro Sul & $2 \%$ & $74 \%$ \\
\hline $8^{\circ}$ & Petro Sul & $2 \%$ & $64 \%$ & $8^{\circ}$ & Satelite & $2 \%$ & $76 \%$ \\
\hline $9^{\circ}$ & Ask & $2 \%$ & $66 \%$ & $9^{\circ}$ & Fic & $2 \%$ & $78 \%$ \\
\hline $10^{\circ}$ & Gianpetro & $2 \%$ & $68 \%$ & $10^{\circ}$ & Repsol YPF & $1 \%$ & $79 \%$ \\
\hline $11^{\circ}$ & Aster & $2 \%$ & $70 \%$ & $11^{\circ}$ & SP & $1 \%$ & $80 \%$ \\
\hline $12^{\circ}$ & Centro Sul & $1 \%$ & $72 \%$ & $12^{\circ}$ & Total & $1 \%$ & $81 \%$ \\
\hline $13^{\circ}$ & Uberlândia & $1 \%$ & $73 \%$ & $13^{\circ}$ & $\overline{C J}$ & $1 \%$ & $82 \%$ \\
\hline $14^{\circ}$ & Ale & $1 \%$ & $74 \%$ & $14^{\circ}$ & Sabba & $1 \%$ & $83 \%$ \\
\hline $15^{\circ}$ & Flag & $1 \%$ & $75 \%$ & $15^{\circ}$ & Flag & $1 \%$ & $84 \%$ \\
\hline $16^{\circ}$ & Ocidental & $1 \%$ & $76 \%$ & $16^{\circ}$ & Idaza & $1 \%$ & $84 \%$ \\
\hline $17^{\circ}$ & Satélite & $1 \%$ & $77 \%$ & $17^{\circ}$ & Petropar & $1 \%$ & $85 \%$ \\
\hline $18^{\circ}$ & Onix & $1 \%$ & $78 \%$ & $18^{\circ}$ & Zema & $1 \%$ & $85 \%$ \\
\hline $19^{\circ}$ & Delta & $1 \%$ & $79 \%$ & $19^{\circ}$ & Aster & $1 \%$ & $86 \%$ \\
\hline $20^{\circ}$ & Geraes & $1 \%$ & $79 \%$ & $20^{\circ}$ & Federal & $0 \%$ & $86 \%$ \\
\hline & $21^{\circ}$ a $162^{\circ}$ & $21 \%$ & $100 \%$ & & $21^{\circ}$ a $164^{\circ}$ & $14 \%$ & $100 \%$ \\
\hline
\end{tabular}

FONTE: Elaborado pelo autor com dados da ANP

Vale comentar que a Distribuidora Ipiranga, que aparece em segundo lugar na Tabela 7, já não pertence ao Grupo Ipiranga. Em 2006, suas operações de distribuição nas regiões norte e nordeste foram adquiridas pela BR Distribuidora, e os ativos de distribuição das regiões sul, sudeste e centro-oeste foram comprados pelo Grupo Ultra (SANTOS; SCHÜFFNER, 2007).

Percebe-se que a distribuição de ambos os combustíveis é bastante concentrada, sendo que a de gasolina C é ainda mais concentrada que a de hidratado. 51\% de toda gasolina C é comercializada por 3 distribuidoras, enquanto $49 \%$ do hidratado é comercializado por 4 
empresas. Todas as distribuidoras que ocupam posições além da $12^{\circ}$ colocação, em torno de 150 empresas, não são responsáveis, cada uma delas, por mais de $1 \%$ das vendas de hidratado ou gasolina C.

De acordo com estes dados, entende-se que a estrutura da demanda formada pelas distribuidoras é de um oligopsônio com franja competitiva.

Além de compreender como se dá a estruturação da demanda formada pelas distribuidoras, uma outra questão relevante ao entendimento da distribuição são as características da logística de escoamento dos combustíveis, que será revisada na próxima seção.

\subsubsection{Logística e fluxos de escoamento}

A distribuição do etanol carburante é feita utilizando três tipos de estruturas físicas para acomodar e encaminhar esse produto: os centros coletores, as bases de distribuição primárias e as bases de distribuição secundárias.

A primeira delas, o centro coletor, tem função de receber, armazenar e encaminhar o etanol. A Petrobras possui 10 centros coletores, sendo 5 deles no Estado de São Paulo (ANP, 2007a). É importante destacar que o centro coletor envia todo volume de etanol a uma base de distribuição, não remetendo o combustível ao mercado consumidor.

Na maioria das vezes, os centros coletores são utilizados nas operações logísticas da Petrobras e da BR Distribuidora (XAVIER, 2007).

As outras duas estruturas são denominadas bases de distribuição. Elas são divididas em bases primárias e secundárias. De acordo com a ANP (ANP, 2007c), existem 551 bases, entre primárias e secundárias, no território nacional. Essas bases têm uma capacidade nominal de armazenamento de $718.929 \mathrm{~m}^{3}$ (ANP, 2007c). As bases de distribuição são formadas pelas operações de armazenamento e transferência das distribuidoras de combustíveis e de outros agentes prestadores de serviços de transporte e transferência como, por exemplo, a Transpetro.

De acordo com o Sindicom (SINDICOM, 2007a), as bases de distribuição mais importantes estão apontadas na Figura 6. Percebe-se que as bases primárias estão mais concentradas na 
região litorânea do país, enquanto as bases secundárias têm maior presença no interior. As bases primárias estão alocadas desta forma, pois são construídas em função da localização das refinarias de petróleo e das estruturas de extração e importação de óleo cru.

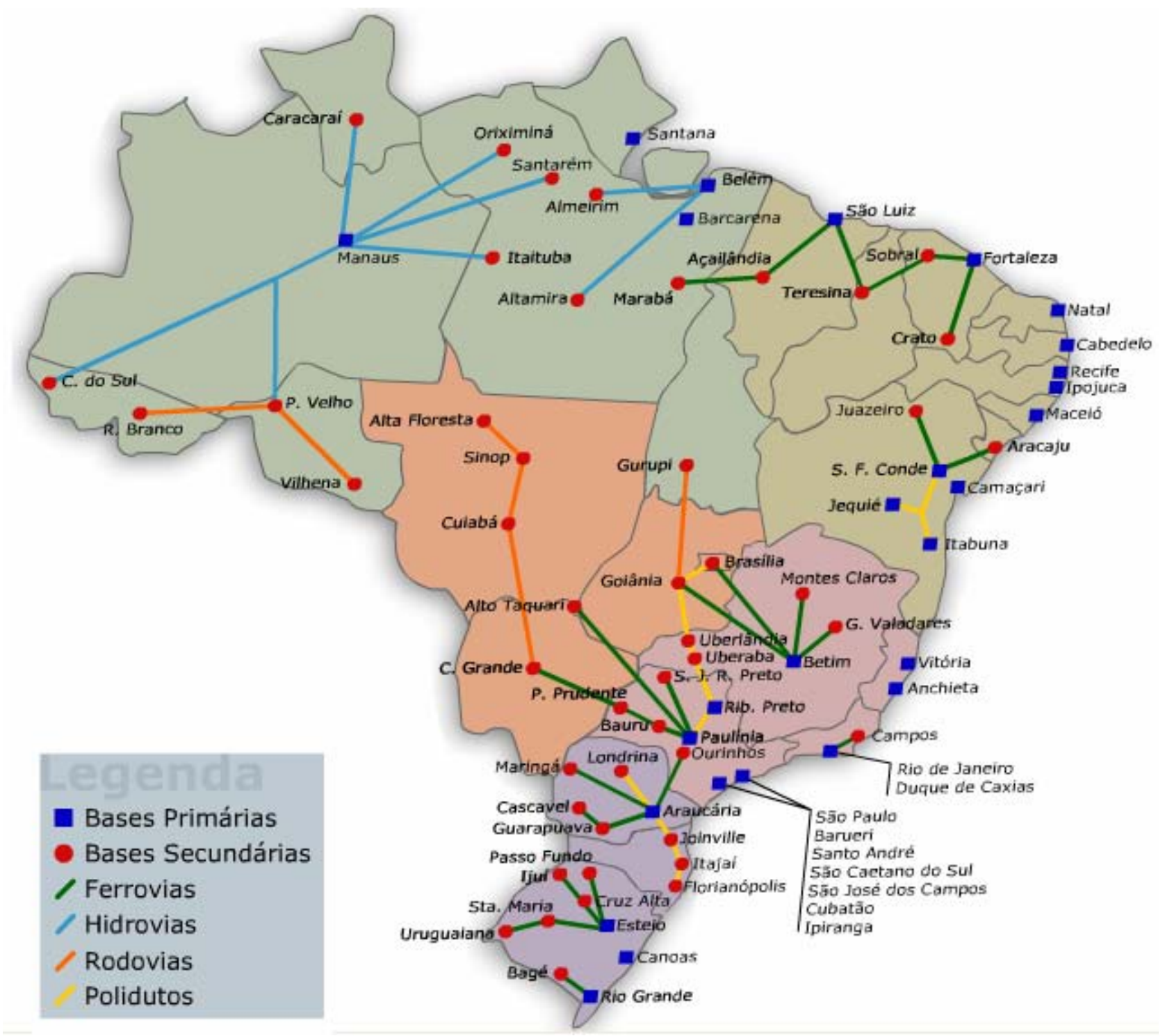

Figura 6: Bases de Distribuição de Combustível FONTE: Sindicom (2007a)

As bases primárias e secundárias não são classificadas assim formalmente. Sua diferenciação é resultado da proximidade às refinarias, como dito anteriormente, assim como do volume de combustível que operam e da presença de diferentes modais de transporte. Quanto maior o volume de combustível operado e quanto maior a capacidade logística, a base deve ser chamada de primária (XAVIER, 2007). 
É importante destacar que ambas as bases, primárias e secundárias, recebem tanto o anidro como o hidratado das usinas, são capazes produzir a gasolina C a partir do anidro e da gasolina $\mathrm{A}$, e podem direcionar o hidratado e a gasolina $\mathrm{C}$ ao mercado consumidor (FIGUEIREDO, 2006; XAVIER, 2007).

A Figura 7 apresentada a seguir, resume os principais fluxos de produto comentados anteriormente.

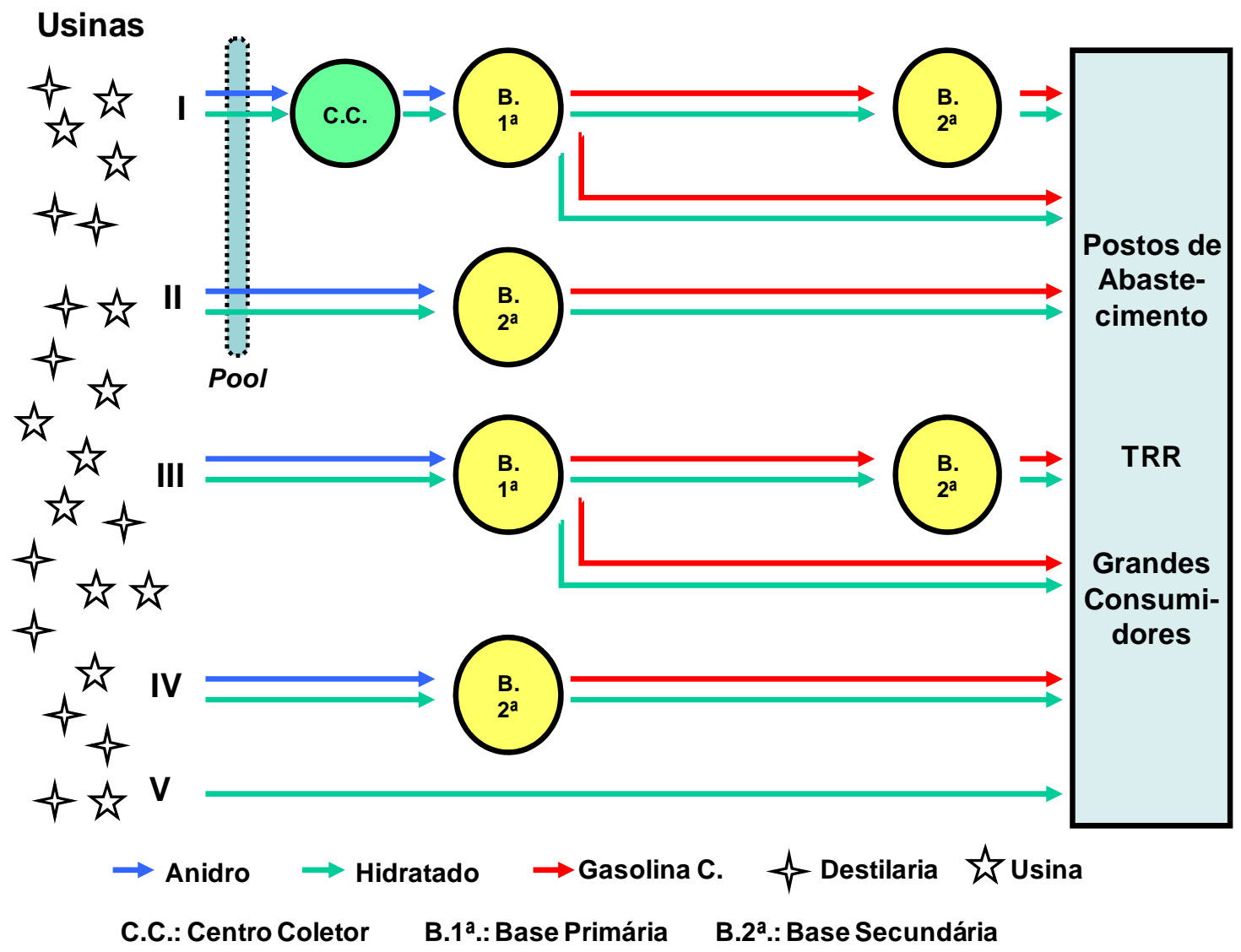

Figura 7: Os principais fluxos de etanol carburante

FONTE: Elaborado pelo autor, com dados de: Sindicom (2007b), Figueiredo (2006)

Na Figura 7, os Fluxos I e II são a representação das vendas por meio de pools de comercialização. No caso do Fluxo I, ocorre a presença do centro coletor, que envia o etanol a uma base primária. Os Fluxos III, IV e V são as vendas de usinas não integradas a grupos de comercialização. Os casos II e IV evidenciam que as usinas podem entregar diretamente a uma base secundária. 
O Fluxo $\mathbf{V}$ representa a venda do hidratado de uma usina a uma distribuidora em que este álcool não passa por uma base de distribuição até ser entregue ao mercado consumidor. Tal procedimento está representado aqui, pois, apesar de ilegal, é também observado no mercado.

Vale comentar que não existe venda direta de etanol das usinas a postos revendedores. Qualquer venda tem que passar por uma distribuidora.

No transporte do etanol durante o processo descrito anteriormente, são usados vários modais, como: dutos, ferrovias, hidrovias e estradas.

Um importante fornecedor de serviços de transporte, a saber, é a Transpetro, Petrobras Transporte S.A., empresa subsidiária da Petrobras e principal empresa de logística e transporte de combustíveis do Brasil. A Transpetro atende às atividades de transporte e armazenagem de petróleo e derivados, álcool e gás natural, operando uma frota de 53 navios, 10 mil quilômetros de malha dutoviária e 43 terminais terrestres e aquaviários (TRANSPETRO, 2007a).

Figueiredo (2006) propõe um modelo para se compreender o fluxo de produtos durante a distribuição de combustíveis líquidos. De acordo com a Figura 8, podemos observar três fluxos principais: primário, de transferência e de entrega.

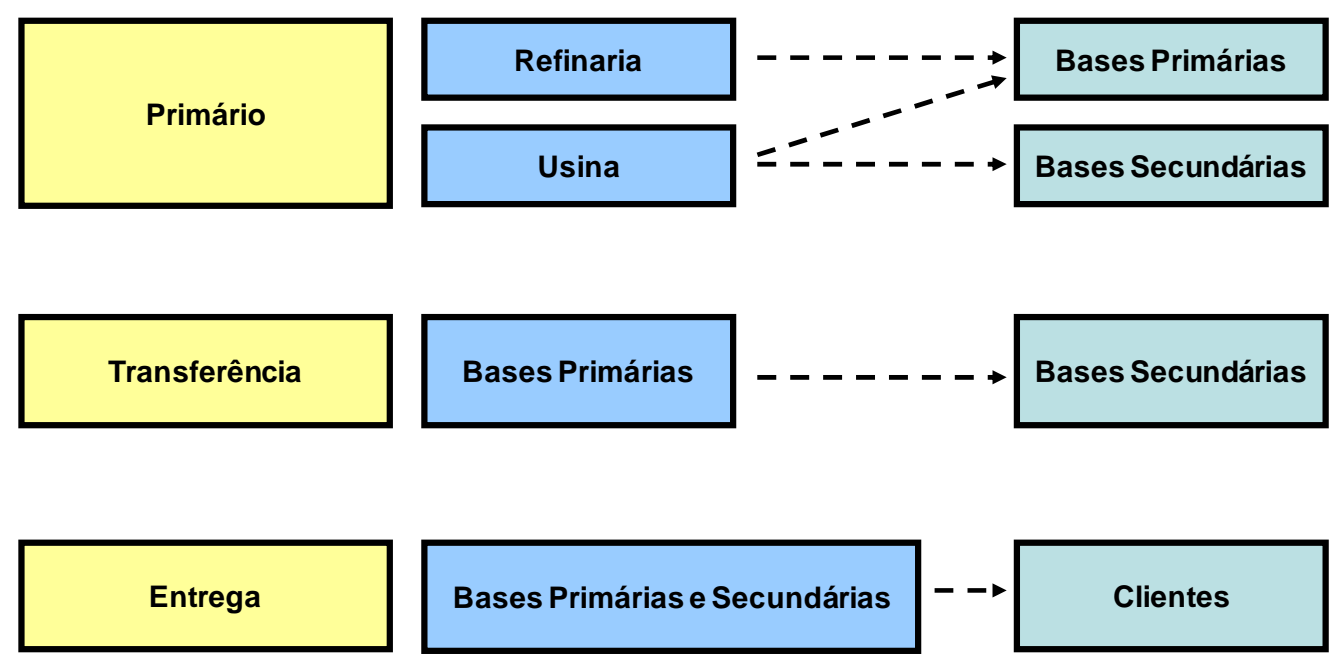

Figura 8: Os Três fluxos existentes na distribuição de combustíveis FONTE: Figueiredo (2006) 
O Fluxo Primário corresponde ao etanol saindo das usinas e centros coletores em direção às bases primárias e secundárias. Neste fluxo, os modais mais utilizados são o ferroviário e o rodoviário.

A Transferência seria o transporte do combustível das bases primárias para as secundárias no intuito de aproximar esses estoques do mercado consumidor. Nesse caso, os modais mais usados, no caso dos combustíveis em geral e do etanol, também são as ferrovias e as rodovias.

As Entregas ocorrem praticamente através de rodovias. Elas são feitas a partir de bases primárias e secundárias para os agentes que compõem o varejo. A rodovia é a mais adequada nesse caso, devido ao destino ser pulverizado e estar, na maioria dos casos, a um raio de aproximadamente $200 \mathrm{Km}$ das bases de distribuição (FIGUEIREDO, 2006).

A Transpetro é a empresa que oferece o serviço de transporte de combustíveis em dutos, tanto em casos de fluxo de transferência entre bases, através dos chamados dutos longos, como o de pequenas transferências internas às bases ou entre pequenas distâncias entre bases e terminais, nos chamados dutos curtos (TRANSPETRO, 2007b, 2007c e 2007d). Vale ressaltar que Figueiredo (2006) utiliza a terminologia "transferência” sempre que a movimentação ocorre entre bases, enquanto a Transpetro utiliza este termo para qualquer processo de transporte de combustível.

Os dutos da Transpetro são usados para vários produtos, sendo considerados polidutos ${ }^{45}$. Não existe nenhum duto dedicado apenas ao transporte de etanol.

\footnotetext{
${ }^{45}$ Os polidutos transportam combustíveis líquidos como gasolina, diesel e petróleo.
} 
Os sistemas dutoviários podem ser visualizados na Figura 9, apresentada a seguir.

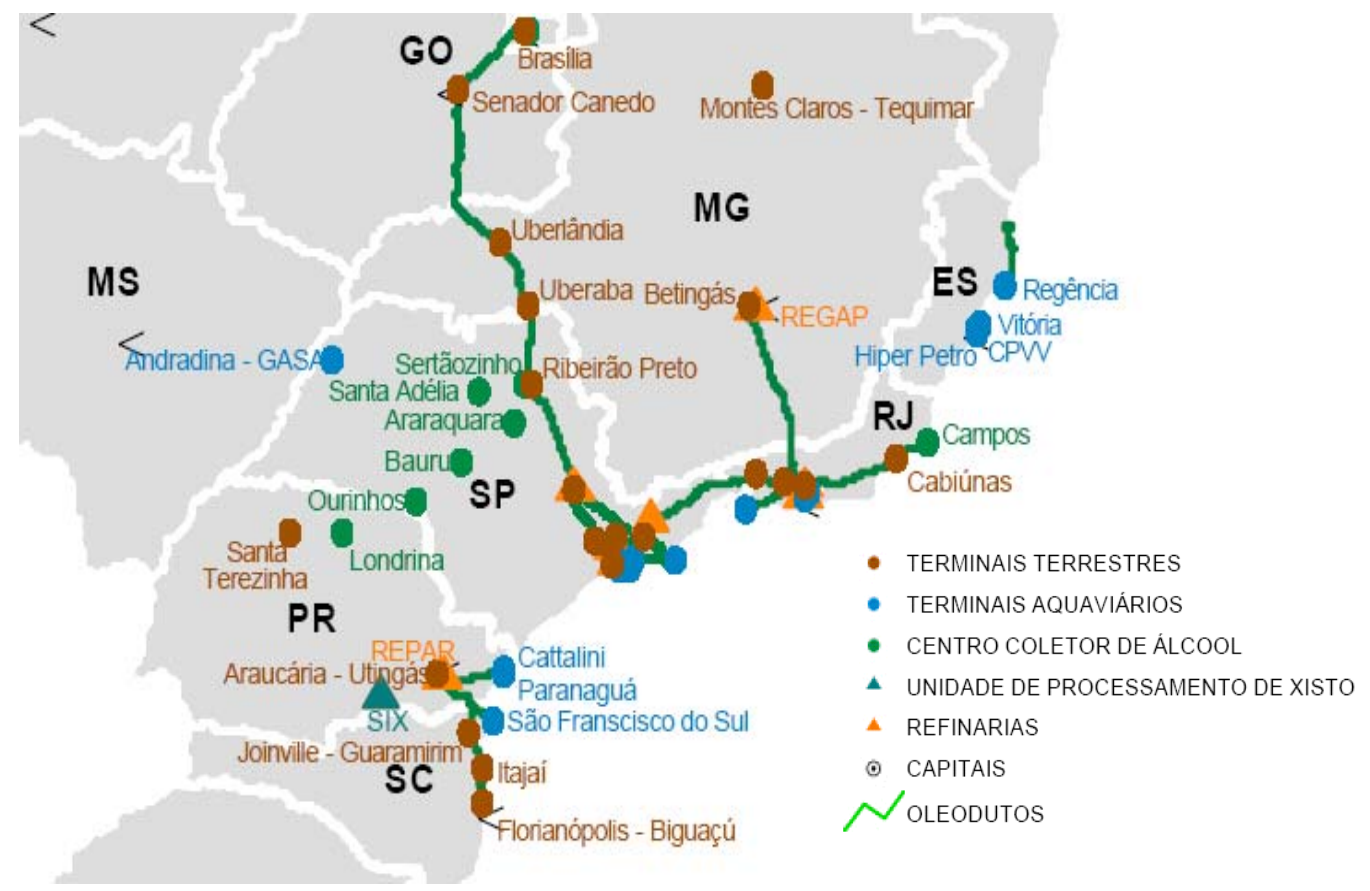

Figura 9: Cartograma de infra-estrutura para movimentação de petróleo e etanol FONTE: Adaptado pelo autor de ANP (2005 d)

\subsection{Instituições e organizações}

O etanol, tanto anidro como hidratado, é um produto de atributos bem definidos. A especificação técnica destes produtos têm sido continuamente aperfeiçoada e formalizada em publicações da ANP. No ano de 2005, houve a publicação da Resolução ANP $\mathrm{n}^{0}$ 36, colocando em vigor a última atualização desta especificação.

Commodities como o etanol têm essa característica: não se pode averiguar qualquer diferença entre os produtos produzidos por diferentes agentes.

No caso do etanol, a moderna tecnologia de produção não é cativa de uma pequena parte dos agentes. Pelo contrário, a tecnologia é bastante difundida.

Desta forma, o sucesso da atividade econômica dos agentes se concentra em duas questões básicas: a capacidade intrínseca de gerenciar custos, industriais no caso das usinas, e custos logísticos no caso das distribuidoras, e o arcabouço institucional que envolve as atividades de produção e distribuição do etanol. 
Entre as instituições que compõem este arcabouço, as formais são as mais relevantes, determinando os contornos do mercado e sendo responsáveis em grande parte pelas oportunidades e riscos que se apresentam aos agentes.

A cadeia de suprimentos do etanol carburante sempre sofreu grande influência das diretrizes apontadas pelo governo. De 1933 a 1990, o setor sucroalcooleiro era controlado diretamente pelo Instituto do Açúcar e Álcool (IAA), que estabelecia os preços e as cotas de produção que deveriam ser seguidos pelos agentes econômicos. Enquanto isso, o mercado de distribuição de combustíveis também seguia regulado diretamente pelo governo federal, por meio dos Ministérios da Fazenda e de Minas e Energia.

\subsubsection{A desregulamentação do setor}

Em 1990, a desregulamentação da economia começou a ser implementada em vários setores produtivos no Brasil. Dentre eles, o setor sucroalcooleiro e a indústria do petróleo. Apesar deste processo, o governo não deixou de influenciar o funcionamento dos mercados, apenas mudou sua forma de intervir. À medida que os mercados foram sendo liberados, o governo foi criando uma série de regras para coordenar a atividade econômica, mantendo sua influência devido à sua autoridade sobre a formação e transformação das regras que compõem o arcabouço institucional do setor.

No setor sucroalcooleiro, a Medida Provisória n 151, de 15 de março de 1990, estabeleceu a extinção do IAA, sendo que as atribuições deste instituto passaram para a Secretaria de Desenvolvimento Regional da Presidência da República.

Em 1997, são criadas três organizações governamentais para gerir a indústria de combustíveis e o setor sucroalcooleiro, para adequar o relacionamento do governo com os agentes econômicos neste processo de flexibilização. A Lei 9.478/97, de 06 de agosto de 1997, criou o CNPE (Conselho Nacional de Política Energética), responsável por estabelecer as diretrizes da política energética e a ANP (Agência Nacional do Petróleo), responsável por regular a indústria do petróleo. O CIMA (Conselho Interministerial do Açúcar e Álcool) foi criado para articular os interesses de todos os ministérios envolvidos com o sistema sucroalcooleiro em direção a um consenso sobre o processo de desregulamentação. Ainda em 1997, uma 
importante organização não governamental de representação setorial é criada, a UNICA, União da Indústria de Cana-de-açúcar.

O afastamento do governo do controle direto dos mercados foi marcado por um processo gradativo de liberação de preços. A Portaria MF n. ${ }^{0}$ 59, de 29 de março de 1996, liberou os preços de venda das distribuidoras e dos revendedores para a gasolina e o etanol hidratado em praticamente todo território nacional, a exceção de alguns municípios da região norte supridos pelo modal fluvial. A Portaria MF n. ${ }^{\circ}$ 294/96, de 13 de dezembro de 1996 liberou os preços de venda do anidro nas unidades produtoras. A Portaria MF n. ${ }^{\circ}$ 292/96, de 16 de dezembro de 1996, reduziu o subsídio ao hidratado em todo território nacional e liberou os preços deste e da gasolina em todo território nacional. Vale comentar que duas outras medidas neste sentido foram editadas em 1999 e 2002, completando o conjunto de medidas que permitiram a completa liberação dos preços, a saber: a Portaria MF/MME n. ${ }^{\circ}$ 28/99, de 9 de março de 1999, liberou os preços nos postos de gasolina C e hidratado ao consumidor em todo território nacional e, em 2002 a gasolina A passou a não ser mais precificada pelo governo federal.

\subsubsection{O Estado e o delineamento dos mercados}

Algumas vezes, as regras impostas pelo governo vão além da regulação da atividade dos agentes, chegando, literalmente, a criar, ou extinguir, um mercado para determinado combustível de maneira mandatória. Este tipo de processo foi sempre marcante no histórico da utilização do etanol como combustível no Brasil.

Após a crise do petróleo de 1973, o Governo Brasileiro editou o Decreto nº 76.593 criando o Programa Nacional do Álcool (Proálcool), estimulando a indústria nacional a produzir etanol em resposta ao aumento do preço do petróleo e para evitar um desequilíbrio maior no balanço das contas externas do país, devido à importação de petróleo em larga escala. Em sua primeira fase, entre 1975 e 1979, o foco do programa era o estímulo à produção de anidro para ser misturado à gasolina. De 1979 a 1985 o foco voltou-se para produção do hidratado como combustível veicular. Percebe-se que em ambas as fases o governo criou a demanda para os produtos de maneira mandatória, impondo a prática de adição do anidro à gasolina e, na segunda fase, garantindo uma paridade de preço entre o hidratado e a gasolina num patamar capaz de manter o interesse dos consumidores pelo hidratado. 
Vale comentar que o Proálcool teve grande impacto sobre a indústria de cana nacional devido ao volume de investimentos injetado no setor durante o programa. Estes investimentos foram imprescindíveis ao ganho de escala necessário para que um produto agrícola como o etanol pudesse vir a participar do mercado de combustíveis líquidos.

Em 1993, o governo instituiu a mistura obrigatória de 22\% de anidro à gasolina, criando novamente um mercado para o etanol de forma mandatória, que seguiu operando assim até 2008, sendo que a quantidade de anidro foi alterada para um valor entre 20 a $25 \%$ da gasolina, a ser indicada pelo CIMA.

Não só no Brasil, um mercado para determinado combustível é criado, ou extinto, por determinação governamental. Em 2003, o MTBE, aditivo usado nos EUA na mistura da gasolina, foi banido por força legal dos estados da Califórnia, Nova York e Connecticut, gerando um aumento de demanda por etanol, para substituí-lo.

Uma forma específica de influenciar os contornos do mercado de combustíveis é o controle estatal dos impostos e subsídios aplicados ao setor. Um exemplo disso seria o caso do sucesso do hidratado como combustível veicular frente à gasolina, em alguns estados brasileiros, a partir da introdução do carro flex, em 2003. Em 2008, o hidratado teve um preço competitivo frente à gasolina $\mathrm{C}$ nos postos de abastecimento devido à menor carga tributária paga na sua cadeia produtiva. Entre os impostos voltados à distribuição de combustíveis, destaca-se a CIDE, Contribuição de Intervenção sobre o Domínio Econômico, que incide sobre a comercialização de gasolina, mas não se aplica ao hidratado.

Um exemplo da influência dos estados sobre o delineamento dos mercados no âmbito internacional é a política de importação de etanol determinada pelo governo americano, que estabelece um mercado cativo para determinados países caribenhos pelo Caribean Basin Economic Recovery Act. Nesta política, estes países ficam isentos do pagamento do imposto de importação americano, ao exportarem etanol para este país.

\subsubsection{O Estado e a competitividade entre os agentes econômicos}

A competitividade entre os agentes também é um ponto altamente influenciado pelo regramento imposto pelas autoridades. Vale comentar que, em 1993, a revogação de algumas exigências que impediam a atuação de distribuidoras de pequeno porte pela Portaria MME $n^{\circ}$ 
258 e a autorização para operação de postos bandeira branca pela Portaria MME $\mathrm{n}^{\circ}$ 362, contribuíram diretamente para o aumento da competição no setor de distribuição. De maneira oposta, a Resolução ANP n 7, de 07 de março de 2007, veio reforçar o laço de exclusividade entre os revendedores franqueados e suas distribuidoras de origem, diminuindo a possibilidade de atuação das distribuidoras independentes.

O Quadro 1 apresentado a seguir, coloca de maneira cronológica alguns eventos citados nesta última seção, ao discutir o ambiente institucional e as organizações que compõem a cadeia produtiva do etanol carburante. 
Quadro 1: Cronologia do Ambiente Institucional

\begin{tabular}{|c|c|}
\hline Data & Histórico do Ambiente Institucional \\
\hline 1931 & O etanol passou a ser oficialmente utilizado como aditivo à gasolina \\
\hline 1973 & $1^{\circ}$ Crise do Petróleo \\
\hline 1975 & $\begin{array}{l}\text { Decreto } \mathrm{n}^{0} 76.593 \text {, de 14/11/1975 - Criação do Proalcool ( } 1^{\text {a }} \text { fase, de } 1975 \text { a 1979: Produção de } \\
\text { Anidro para misturar à gasolina) ( } 2^{\text {a }} \text { fase, de1979 a 1985: Produção de hidratado para consumo } \\
\text { veicular) }\end{array}$ \\
\hline 1979 & Segunda Crise do Petróleo \\
\hline 1979 & $\begin{array}{l}2^{\mathrm{a}} \text { fase do Proalcool - (de1979 a 1985: Produção de hidratado para consumo veicular) - Surge } 0 \\
\text { carro à alcool - Garantia de paridade de preço do hidratado e gasolina C em em } 35 \%\end{array}$ \\
\hline 1983 & The Caribean Basin Economic Recovery Act - Define a importação de anidro por países caribenhos \\
\hline 1986 & Cai a a garantia da paridade de preços de hidratado $\mathrm{x}$ gasolina $\mathrm{C}$ \\
\hline 1990 & A Medida Provisória n 151, de 15 de março de 1990, estabeleceu a extinção do IAA \\
\hline 1990 & Início do processo de desregulamentação \\
\hline 1993 & $\begin{array}{l}\text { Portaria MME nº 258, de 29/julho de } 1993 \text { - Revoga algumas exigências que impediam a atuação } \\
\text { de distribuidoras de pequeno porte. }\end{array}$ \\
\hline 1993 & Portaria MME nº 362 - Autorização para operação de postos bandeira branca. \\
\hline 1993 & O governo institui a mistura obrigatória de 22\% de anidro à gasolina \\
\hline 1996 & $\begin{array}{l}\text { A - Portaria MF n. }{ }^{\text {5 }} \text { 59, de } 29 \text { de março de } 1996 \text { - liberação dos preços de venda das distribuidoras e } \\
\text { dos revendedores para a gasolina e o álcool hidratado em praticamente todo território nacional, a } \\
\text { exceção de alguns municípios da região norte supridos pelo modal fluvial. (Marca o Início da } \\
\text { liberação dos PREÇOS) }\end{array}$ \\
\hline 1996 & $\begin{array}{l}\text { B - Portaria MF n. }{ }^{\circ} \text { 294/96, de } 13 \text { de dezembro de 1996. - Liberação dos preços de venda do álcool } \\
\text { anidro nas unidades produtoras, prevista para } 1^{\circ} \text { de maio de } 1997 .\end{array}$ \\
\hline 1996 & $\begin{array}{l}\text { C - Portaria MF n. }{ }^{\circ} \text { 292/96, de } 16 \text { de dezembro de } 1996 \text { - redução do subsídio ao álcool hidratado } \\
\text { em todo território nacional e liberação dos preços deste e da gasolina em TODO território nacional. }\end{array}$ \\
\hline 1997 & Criação da ÚNICA - União da Industria de Cana-de-açúcar \\
\hline 1997 & Criação do CIMA - Conselho Interministerial do Açúcar e Álcool (CIMA) \\
\hline 1997 & $\begin{array}{l}\text { Lei 9.478/97, de } 06 \text { de agosto de } 1997 \text { - Criação da ANP (Agência Nacional do Petróleo), } \\
\text { responsável por regular a indústria do petróleo. }\end{array}$ \\
\hline 1997 & $\begin{array}{l}\text { Lei 9.478/97, de } 06 \text { de agosto de } 1997 \text { - Criação do CNPE (Conselho Nacional de Política } \\
\text { Energética), responsável por estabelecer as diretrizes da política energética }\end{array}$ \\
\hline 1999 & $\begin{array}{l}\text { Portaria MF/MME n. }{ }^{\circ} \text { 28/99, de } 9 \text { de março de 1999. - Liberação dos preços nos postos de gasolina } \\
\text { c e hidratado ao consumidor em todo território nacional. }\end{array}$ \\
\hline 2001 & $\begin{array}{l}\text { Lei no } 10.336 \text {, de 19/12/2001 - Instituiu a cobrança da CIDE (Contribuição de Intervenção sobre o } \\
\text { Domínio Econômico). destinada ao pagamento de subsídios a preços ou transporte de álcool } \\
\text { combustível; ao financiamento de projetos ambientais relacionados com a indústria de } \\
\text { combustíveis; e ao financiamento de programas de infra-estrutura de transportes. }\end{array}$ \\
\hline 2003 & Lei Estadual nº 11.593 de 04.12.2003 - Baixou ICMS de 25 para 12 em S.P. \\
\hline 2003 & Carro flex-fuel chega ao mercado nacional \\
\hline 2003 & Banimento do MTBE na Califórnia, Nova Iorque e Connecticut \\
\hline 2005 & $\begin{array}{l}\text { Resolução ANP ñ 36, de } 6 \text { de dezembro de } 2005 \text { - Define a especificação técnica em vigor (até } \\
\text { 2008) do etanol }\end{array}$ \\
\hline 2007 & $\begin{array}{l}\text { Resolução ANP } \mathrm{n}^{\circ} \text { 7, de 07/março de } 2007 \text { - Punição a distribuidoras que venderem a postos } \\
\text { bandeirados }\end{array}$ \\
\hline
\end{tabular}

FONTE: Elaborado pelo autor com dados de: ANP, MAPA e MORAES (1999) 


\section{HIPÓTESE E OBJETIVOS DA PESQUISA}

Este capítulo irá abordar a formulação das hipóteses desta pesquisa e apontar quais os resultados esperados nesta fase de proposição de objetivos. Estes dois assuntos, respectivamente, correspondem às etapas 4 e 5 do modelo de Richardson (1999), referido no quadro 1 e adotado neste trabalho.

Como será visto a seguir, a formulação de hipóteses está sempre ligada diretamente aos objetivos da pesquisa. Sendo assim, o capítulo apresentará três seções para dar cabo do conteúdo que pretende apresentar. A seção 5.1 abordará o objetivo geral e as hipóteses lançadas, a seção 5.2 tratará dos objetivos específicos e da natureza da pesquisa e, por fim, a seção 5.3 discutirá os resultados esperados.

\subsection{Objetivo geral e hipótese}

Richardson (1999, p. 62) define o termo objetivo geral de pesquisa como sendo "o que se pretende alcançar com a realização da pesquisa”.

No capítulo 1, seção 1.2.1, foi colocado que o objetivo deste trabalho é a geração de um modelo teórico. Contando com as informações referenciais objetivas apresentadas anteriormente e com o aporte teórico oferecido pela NEI, pôde-se elaborar de maneira mais específica o objetivo do trabalho, que, a partir de agora, será indicado pelo termo objetivo geral, assim como sugere Richardson (1999).

Richardson (1999, p. 62) comenta que o objetivo geral de uma pesquisa "deriva diretamente do problema de pesquisa” que se pretende responder. Em outras palavras, o objetivo geral da pesquisa é responder o problema de pesquisa levantado.

Elaborando o conceito de objetivo geral da pesquisa sob a ótica da NEI e valendo-se das informações referenciais, constatou-se que o objetivo do trabalho poderia ser indicado como: formular um modelo de análise teórico que indicasse os determinantes da escolha da estrutura de governança na comercialização de etanol entre usinas e distribuidoras de combustíveis no Brasil. 
Vale ressaltar que a indicação dos determinantes, conforme colocado nesta descrição de objetivo geral, refere-se tanto à indicação de quais seriam estes determinantes, como à explicação de como eles estariam afetando a escolha da estrutura de governança.

Para cumprir o objetivo geral do trabalho, foi lançado o seguinte teste de hipótese:

H0: De acordo com a NEI, custos de transação não justificam a escolha de governança na relação entre usinas e distribuidoras de combustíveis.

H1: De acordo com a NEI, custos de transação justificam a escolha de governança na relação entre usinas e distribuidoras de combustíveis.

A hipótese alternativa (H1) tem uma peculiaridade: para que seja possível testá-la será necessário, invariavelmente, confirmar a existência e caracterizar os custos de transação.

Dito isto e tomando como resultado esperado a confirmação de $\mathrm{H} 1^{46}$, pode-se observar que o cumprimento do objetivo geral do trabalho, o estabelecimento da racionalidade econômica da transação, será obtido à medida que se confirmar a existência e a caracterização dos custos de transação e se confirmar a hipótese H1, conforme ilustra a Figura 10.

Vale comentar que, após a caracterização dos custos de transação, também existe a possibilidade de não se confirmar H1, o que também ofereceria substrato para a proposição do modelo teórico, que, no caso, indicaria a inadequação da ECT como aporte teórico.

Objetivo Geral

A confirmação da existência e a caracterização dos custos de transação, somada à confirmação de H1

\section{Resposta ao problema de pesquisa}

Estabelecimento da racionalidade econômica da transação

Figura 10: Objetivo geral do trabalho

FONTE: Elaborado pelo autor

\footnotetext{
${ }^{46}$ A discussão envolvendo a predição do resultado será desenvolvida na seção 5.2.3
} 


\subsubsection{Detalhamento do teste de hipótese.}

Conforme o teste de hipótese proposto na seção anterior, as variáveis selecionadas foram: a estrutura de governança e os custos de transação. Estas variáveis referem-se à transação e, por qualificarem a transação, podem ser chamadas de atributos da mesma.

A transação, unidade de análise utilizada na NEI, também foi adotada para este trabalho, permitindo o uso deste aporte teórico para responder de forma adequada ao problema de pesquisa. Esta escolha, além de proporcionar a possibilidade de usar este aporte teórico, também satisfaz a condição colocada por Collis e Hussey (2005, p. 146) de que "uma variável deva ser um atributo da unidade de análise” que está sendo adotada na pesquisa.

Estrutura de governança é uma variável qualitativa discreta. No caso, é a variável dependente deste teste de hipótese.

Custo de transação também é uma variável qualitativa, porém contínua. No caso, é a variável independente do teste.

Collis e Hussey (2005, p. 125) indicam duas condições para que uma hipótese seja válida sob um paradigma de pesquisa positivista. A primeira diz que uma hipótese deve "identificar a variável dependente e a variável independente”. A segunda diz que uma hipótese deve ser uma afirmação sobre a relação entre estas variáveis. No caso deste trabalho, ambas as condições foram respeitadas.

Vale comentar que optou-se por adotar o sentido afirmativo para H1, pois a NEI, mais especificamente a ECT, sugere este sentido. Collis e Hussey (2005, p. 124) afirmam que, “por vezes, a teoria sugere que há uma direção possível para a relação”, classificando a hipótese que carrega esta sugestão como hipótese direcional.

\subsection{Natureza e objetivos específicos da pesquisa}

Nesta seção serão descritos os objetivos específicos que apontaram para que fosse possível testar a hipótese lançada. Para finalizar a seção, serão colocados os resultados esperados da pesquisa ainda nesta fase, antes da realização da coleta e análise de dados. 
Antes de entrar nestes dois assuntos, vale lembrar que a natureza da pesquisa influencia diretamente a proposição dos objetivos específicos.

Hair et al (2005) usam três categorias para classificar uma pesquisa: a exploratória, a descritiva e a causal. Para os autores (op. cit.), na pesquisa exploratória, o objetivo é aproximar-se do fenômeno ou conseguir nova compreensão dele, freqüentemente, para que pesquisas futuras consigam formular um problema mais preciso de pesquisa ou criar novas hipóteses. A pesquisa descritiva apresenta, precisamente, as características de uma situação, ou então estabelece relações entre variáveis. Já a pesquisa causal procura verificar uma hipótese de relação causa e efeito entre variáveis.

As pesquisas podem possuir características de mais de uma das categorias citadas anteriormente, pois estas não são mutuamente excludentes. Selltiz et al (1974, p. 59) destacam que: "na prática, estes tipos de estudo nem sempre são nitidamente separáveis. Qualquer pesquisa considerada pode conter elementos de duas ou mais funções descritas como características de diferentes tipos de estudo.”

No caso deste trabalho, a necessidade de ainda buscar informações básicas sobre a ocorrência do fenômeno indicou o caráter exploratório da pesquisa, a necessidade de apontar quais seriam os custos de transação na relação entre usinas e distribuidoras indicou o caráter descritivo e, por fim, a necessidade de analisar se estes custos de transação seriam responsáveis pela escolha de estrutura de governança indicou o caráter causal. Desta forma, pode-se dizer que este trabalho teve uma natureza tríplice.

\subsubsection{Objetivos específicos}

Conforme colocado no início deste capítulo, durante a discussão do objetivo geral do trabalho $^{47}$, estabeleceu-se que a racionalidade econômica da relação entre usinas e distribuidoras, pode ser equacionada ao se confirmar H1 e caracterizar os custos de transação desta relação.

\footnotetext{
${ }^{47}$ Este assunto está resumido na Figura 10, seção 5.1
} 
Para alcançar estes dois objetivos, resolveu-se propor uma teoria substantiva ${ }^{48}$ sobre a relação usina / distribuidora a partir de dados a serem coletados em campo. Em última instância, se uma teoria substantiva sobre esta transação poder ser gerada empiricamente e comparada à teoria geral de maneira científica, a adequação da teoria substantiva à geral confirmaria H1 e, para gerar tal teoria substantiva, seria imprescindível apontar e caracterizar os custos de transação. Vale ressaltar que esta proposta trata os objetivos simultaneamente, fazendo com que a pesquisa tenha a natureza múltipla, apontada na seção 5.2.1.

Por tratar exatamente da proposição de teorias substantivas a partir de dados coletados em campo, a metodologia da Teoria Fundamentada em Dados (Grounded Theory) foi escolhida para pautar a condução desta proposta.

O modelo de avaliação contratual de Bogetoft e Olesen foi escolhido para estruturar três processos: a coleta dos dados em campo, a proposição da teoria substantiva e a análise da adequação da teoria substantiva gerada à teoria geral da NEI.

Resolveu-se adotar como método de coleta de dados o método de entrevistas. Quanto ao método de análise dos dados, optou-se pelo método de Grounded Theory ${ }^{49}$

Discussões mais aprofundadas sobre a metodologia, coleta e análise dos dados, serão apresentadas no capítulo 6.

\subsubsection{Resultado esperado}

Conforme sugere a NEI, esperava-se a confirmação de H1 a partir do experimento proposto.

De acordo com os objetivos específicos apontados anteriormente, percebe-se que se optou por uma metodologia qualitativa para conduzir a fase empírica da pesquisa. Devido à grande falta de informações e dados publicados sobre o setor e à grande preocupação dos agentes ${ }^{50}$ com a confidencialidade das informações internas de suas organizações, percebeu-se que a melhor

\footnotetext{
${ }^{48}$ O conceito de teoria substantiva, proposto por Strauss e Glaser (1967), os criadores da Metodologia Grounded Theory, refere-se à teoria que descreve uma situação específica. Para estes autores, o termo teoria substantiva equivale ao termo modelo teórico usado neste trabalho até agora. Este conceito será discutido amplamente no capítulo 6.

${ }^{49}$ Como será visto no capítulo 6, existe tanto a metodologia de Grounded Theory, como o método de análise Grounded Theory. Neste capítulo serão apresentadas as características e propostas de ambas.

${ }^{50}$ A preocupação com a confidencialidade ficou patente nas entrevistas com a SCA e com a Petroluna
} 
forma de realizar a pesquisa seria por meio de um estudo qualitativo. Sendo assim, a expectativa deste trabalho deveria seguir o padrão de expectativa de qualquer pesquisa qualitativa, ou seja, obter um resultado de alta validade ${ }^{51}$ e baixa confiabilidade ${ }^{52}$.

Devido às peculiaridades da metodologia escolhida, que serão apresentadas no decorrer do próximo capítulo, ficará claro que a Grounded Theory não é a mais subjetiva das metodologias fenomenológicas. Bandeira-de-Mello (2007) considera que esta metodologia está posicionada no centro do contínuo ${ }^{53}$ entre objetividade e subjetividade que caracteriza a contraposição entre o paradigma positivista e o fenomenológico. Desta forma, se espera obter um resultado com características tanto positivistas como fenomenológicas, como ilustra o Quadro 2 apresentado a seguir. Neste quadro, usando o recurso da cor azul, estão evidenciadas as características esperadas para esta pesquisa ao ter sido adotada a metodologia em questão.

Quadro 2: Características desta pesquisa: conduzida num paradigma positivista, utilizando uma metodologia fenomenológica

\begin{tabular}{|l|l|}
\hline \multicolumn{1}{|c|}{ Características Positivistas } & \multicolumn{1}{c|}{ Características Fenomenológicas } \\
\hline Objetivo & Subjetivo \\
\hline Imparcial & Parcial \\
\hline Tende a produzir dados quantitativos & Tende a produzir dados qualitativos \\
\hline Interessa-se por testes de hipótese & Interessa-se pela geração de teorias \\
\hline Os dados são altamente específicos e precisos & Os dados são plenos de significado e subjetivos \\
\hline A localização é artificial & A localização é natural \\
\hline A confiabilidade é alta & A confiabilidade é baixa \\
\hline A Validade é baixa & A validade é alta \\
\hline Generaliza de amostra para população & Generaliza de um cenário para outro \\
\hline Valoriza a estrutura teórica & Valoriza menos a estrutura teórica \\
\hline
\end{tabular}

FONTE: Elaborado pelo autor, com base em Collis e Hussey (2005, p.61)

\footnotetext{
${ }^{51}$ Para Collis e Hussey (2005, p.64), o conceito de validade "refere-se a até que ponto as descobertas da pesquisa representam de maneira precisa o que está realmente acontecendo” numa determinada situação.

${ }^{52} \mathrm{O}$ conceito de Confiabilidade refere-se à capacidade que uma pesquisa tem de ser replicável (COLLIS e HUSSEY, 2005, p.63)

${ }^{53}$ Conceito já abordado no capítulo 1, seção 1.3 .1
} 


\section{METODOLOGIA}

Richardson (1999, p. 22) define metodologia como sendo o conjunto de "regras estabelecidas para o método científico”. Para Collis e Hussey (2005, p. 61), a "metodologia refere-se à maneira global de tratar o processo de pesquisa, da base teórica até a coleta e análise de dados."

Para abordar o conteúdo conforme a definição dos autores supracitados, este capítulo está estruturado em três partes: a primeira parte é a introdução à metodologia de Grounded Theory, apontando as características e princípios metodológicos que irão determinar o andamento da coleta e da análise dos dados, além de influenciar a escolha do modelo teórico. As segunda e terceira partes referem-se aos métodos de coleta e análise de dados escolhidos: o método de coleta por meio de entrevistas e o método de análise pela Grounded Theory.

Vale esclarecer que Grounded Theory é tratada por seus criadores, Anselm Strauss e Barney Glaser, como um método de pesquisa que também pode ser adotado como metodologia (GLASER E STRAUSS, 1967 e STRAUSS e CORBIN, 1998). Collis e Hussey (2005), e Bandeira-de-Mello (2007) também compartilham da mesma posição.

Outro fator que deve ser considerado logo de início ao discutir a Grounded Theory é o fato de existirem duas vertentes aceitas para esta metodologia. A primeira delas é mais subjetiva e deriva dos trabalhos de Glaser (1978, 1992 e 1998), a segunda vertente, fruto dos trabalhos de Strauss (1987) e Strauss e Corbin (1990 e 1998), é mais objetiva.

Para Bandeira-de-Mello (2007, p. 244), “a vertente de Strauss e Corbin é mais prescritiva, ao sugerir uma série de procedimentos, técnicas e uma formatação mais estruturada para a teoria gerada”. O autor (op. cit.) também entende que esta vertente é mais específica na delimitação da pesquisa, podendo inclusive ser iniciada focalizando uma questão predeterminada.

Em referência às etapas do método científico de Richardson (1999), este capítulo, somado à apresentação de resultados que será o tema do próximo capítulo, compõe a etapa de número 6, chamada pelo autor (op. cit.) de etapa de experimento. 


\subsection{A metodologia de Grounded Theory}

Para caracterizar a Grounded Theory, serão abordados seus objetivos, seu processo fundamental e os atributos necessários ao pesquisador que utiliza esta metodologia.

\subsubsection{Objetivo}

“A Grounded Theory tem como objetivo gerar explicações, com a mínima intervenção do pesquisador, sobre a ação dos indivíduos em um contexto delimitado, a partir da realidade deles: porque e como determinado grupo age, ou interage, com outros grupos, em situações contextuais específicas e delimitadas” (BANDEIRA-DE-MELLO, 2007, p. 242).

Goulding (2002) também considera que esta metodologia é mais adequada ao estudo da ação coletiva e das interações entre indivíduos e a sociedade, e não à explicação da ação individual ou da sociedade com um todo.

Bandeira-de-Mello (2007) complementa o entendimento do objetivo desta metodologia ao apontar que o produto final da Grounded Theory é uma teoria substantiva, ou seja, uma teoria que explica uma situação específica, uma teoria cujo escopo é restrito.

Comparando o objetivo geral desta pesquisa ao objetivo da metodologia em questão, deve-se atentar à afinação entre ambas, pois a Grounded Theory pretende gerar uma teoria substantiva que explique um determinado fenômeno, e o objetivo desta pesquisa é determinar a racionalidade, uma teoria substantiva, da relação entre usinas e distribuidoras, um fenômeno específico.

\subsubsection{O Processo de pesquisa}

O processo fundamental desta metodologia pode ser resumido como a comparação constante e sistemática entre similaridades e diferenças encontradas nos dados colhidos em campo, visando a geração de uma teoria que reflita a realidade sobre o que se observa (BANDEIRADE-MELLO, 2007; COLLIS; HUSSEY, 2005; GLASER; STRAUSS, 1967; STRAUSS; CORBIN, 1990). 
O pensamento comparativo e sistemático faz uso de indução e dedução. Bandeira-de-Mello (2007, p. 252) o define como um longo processo de "propor e checar” afirmações derivadas dos dados até encontrar consistência e robustez em seu conteúdo explicativo. Na Grounded Theory a fundamentação empírica está ai, no processo de propor e checar à exaustão. Vale comentar que o autor (op. cit.) prefere o termo Inferência Abdutiva para referir-se ao uso concomitante de indução e dedução.

Collis e Hussey (2005, p. 78) acompanham esse racional enquanto afirmam que "é esse método indutivo/dedutivo e a constante referência aos dados, que ajudam a fundamentar a teoria”.

Vale esclarecer que o método indutivo/dedutivo é usado durante a condução do processo de pesquisa, mas, se for feita uma apreciação focada apenas no resultado final, deve-se apontar o método indutivo como método de pesquisa. Algumas definições trazem apenas esta leitura como é o caso das palavras usadas por Strauss e Corbin (1990, p. 24) ao definirem a metodologia como "um conjunto sistemático de procedimentos para desenvolver uma teoria fundamentada derivada indutivamente sobre um fenômeno”.

A estruturação deste processo de propor e checar é feita a partir da categorização das informações colhidas (GLASER E STRAUSS, 1967). À medida que as informações são obtidas e categorizadas, a relação entre as categorias orienta o pensamento crítico do pesquisador à proposição de hipóteses que poderão ser checadas a partir da obtenção de novas informações. Como visto, o processo de propor e checar é iniciado e terminado inúmeras vezes durante a pesquisa, de maneira sistemática, conferindo um caráter de circularidade ao processo (BANDEIRA-DE-MELLO, 2007).

A circularidade tem uma conseqüência importante: a concomitância entre coleta e análise (GLASER; STRAUSS, 1967). Esta condição, somada à necessidade de raciocinar indutiva e dedutivamente, aproxima estes dois processos de tal forma que eles se tornam indissociáveis. A indissociabilidade entre análise e coleta é uma característica marcante da Grounded Theory, assim como da maioria das metodologias fenomenológicas (COLLIS; HUSSEY, 2005; BANDEIRA-DE-MELLO, 2007). Este assunto estará presente nas discussões sobre o método de coleta e sobre o método de análise que serão apresentadas nas próximas seções. 


\subsubsection{Atributos do pesquisador}

Existem três atributos do pesquisador que, somados, garantem boa parte das condições necessárias à aplicação da Grounded Theory.

Para conduzir uma pesquisa, o pesquisador deverá ser, ao mesmo tempo: imparcial, sensível e interativo (BANDEIRA-DE-MELLO, 2007).

A imparcialidade é a capacidade de não distorcer a realidade observada. O pesquisador deverá ser capaz de não se deixar levar por seus preconceitos ao observar um fenômeno ou colher o depoimento de um entrevistado. Sendo assim, entende-se que a Grounded Theory considera que o pesquisador é capaz de retratar fielmente o que observa.

Sensibilidade é o termo que está sendo usado para apontar a capacidade do pesquisador compreender a realidade à medida que observa os dados. Glaser (1978) define esta capacidade como a habilidade de dar significado aos dados. Na prática, o pesquisador deve buscar compreender a realidade a partir do significado atribuído pelos indivíduos às suas experiências. Nas palavras de Bandeira-de-Mello (2007, p. 249): “ver o mundo através dos olhos deles...”

Conforme colocado anteriormente, o processo fundamental da metodologia é a comparação constante dos dados. Deve-se frisar que o dado em questão é o depoimento de um agente sobre um fato objetivo ou a explicação atribuída pelo agente ao modo como "as coisas funcionam”. Em ambos os casos o dado é fruto da observação do agente e não da observação do pesquisador. O pesquisador deve ter a capacidade, a sensibilidade, de colher o "retrato" da realidade assim como é vista por seu entrevistado.

Os dois atributos apresentados até agora, a imparcialidade e a sensibilidade, somados, são definidos por Glaser (1978) pelo termo: Sensibilidade Teórica ${ }^{54}$.

A interatividade é o último atributo do pesquisador a ser comentado. Para que o processo de propor e checar ocorra sistematicamente e de maneira eficaz é necessário que haja um

\footnotetext{
${ }^{54}$ Theoretical Sensitivity
} 
direcionamento na inquirição para que o conteúdo das propostas possam ser checados. Este direcionamento deverá ser dado pelo pesquisador.

O pesquisador, literalmente, influencia a escolha da direção que vai sendo tomada durante a pesquisa $^{55}$. O pesquisador é imparcial, porém não é inerte. Entre uma entrevista e outra, também existe direcionamento por parte do pesquisador, o que é chamado de Amostragem Teórica por Strauss e Corbin (1998).

Vale esclarecer que os atributos conferidos ao pesquisador na Grounded Theory, apesar de diferentes, não são conflitantes com os pressupostos comportamentais de racionalidade limitada e oportunismo adotados na ECT ${ }^{56}$. A ECT assume que os agentes econômicos podem ser descritos a partir destas características, enquanto a Grounded Theory confere apenas ao pesquisador características diferentes. A rigor, a ECT nem considera o pesquisador como parte do estudo.

\subsection{Método de coleta}

Conforme apontado por Goulding (2002), uma peculiaridade da Grounded Theory é a possibilidade de utilizar diversos tipos de fontes de dados, como: entrevistas, documentos e até observações do próprio pesquisador. Nesta seção será abordado o principal método de coleta adotado nesta pesquisa: a entrevista.

As duas principais formas de classificar uma entrevista são: a profundidade e a forma de condução. Uma entrevista pode variar na profundidade que aborda determinado tema e ser conduzida de maneira mais ou menos estruturada (COLLIS; HUSSEY, 2005; RICHARDSON, 1999). No caso desta pesquisa optou-se por aplicar entrevistas em profundidade e semi-estruturadas.

Para acompanhar a proposta da metodologia adotada e viabilizar a coleta de informações objetivas e subjetivas observou-se a necessidade de entrevistar profundamente os agentes. Para dar a possibilidade do pesquisador seguir uma linha de questionamento preestabelecido

\footnotetext{
${ }^{55}$ Vale comentar que esta é uma das maiores diferenças entre da Grounded Theory e a metodologia de Inquirição Participante, pois, nesta última, o direcionamento da inquirição é estabelecido em conjunto com o entrevistado (COLLIS E HUSSEY, 2005, p. 79).

${ }^{56}$ Estes conceitos foram apresentados no capítulo 2, seção 2.2, item 2.2.1
} 
baseada no modelo de Bogetoft e Olesen (2004) e, ao mesmo tempo, exercer a sensibilidade teórica e a amostragem teórica, resolveu-se pela condução semi-estruturada.

A amostragem teórica implica em definir uma amostra durante o experimento, levando em conta os resultados que vão sendo obtidos ao longo da pesquisa. Sendo assim, definiu-se apenas uma população a ser abordada inicialmente. Vale ressaltar que decidiu-se iniciar a pesquisa antes da confirmação efetiva de que os agentes estariam 100\% disponíveis para ser entrevistados.

O quadro 3 apresentado a seguir aponta a população definida neste início da pesquisa.

Quadro 3: População inicial da pesquisa

\begin{tabular}{|l|}
\hline \multicolumn{1}{|c|}{ População } \\
\hline Usinas não organizadas em Pools de Comercialização \\
\hline Usinas organizadas em Pools de Comercialização \\
\hline Copersucar (Pool de Comercialização) \\
\hline Sociedade Corretora de Álcool (Pool de Comercialização) \\
\hline Bioagência (Pool de Comercialização) \\
\hline CPA Trading (Pool de Comercialização) \\
\hline Usina de grande grupo industrial \\
\hline Usina de pequeno grupo industrial \\
\hline Distribuidora não associada ao Sindicom \\
\hline Distribuidora associada ao Sindicom \\
\hline SINDICOM (Organização representante setorial) \\
\hline ÚNICA (Organização representante setorial) \\
\hline ANP e MAPA - Governo Federal \\
\hline Secretaria da Fazenda - Governo Estadual \\
\hline
\end{tabular}

FONTE: Elaborado pelo autor

A composição do questionário seguiu o modelo teórico de Bogetoft e Olesen (2004) para que a coleta ficasse em harmonia com a análise dos dados, a qual também seria estruturada sobre este modelo teórico ${ }^{57}$. A escolha de uma estrutura pré estabelecida para coletar e analisar os dados evidencia a opção pela vertente de Strauss e Corbin, vertente mais objetiva da metodologia de Grounded Theory.

\footnotetext{
${ }^{57}$ Este ponto será abordado de maneira apropriada na próxima seção.
} 
Para reforçar a objetividade da pesquisa, resolveu-se adotar o método do Incidente Crítico para elaborar o questionário. Flanagan (1954), criador desta técnica, propõe que o pesquisador deve concentrar-se em um fenômeno específico do ambiente em estudo, denominado pelo autor como: incidente crítico, para estruturar sua entrevista em função dele, propondo questões objetivas a respeito dos fatos que influenciam a ocorrência do incidente escolhido. Segundo o autor, ao fazer desta forma, o produto final da entrevista será mais objetivo, claro e consistente.

Como o modelo de Bogetoft e Olesen (2004) já está estruturado sobre um incidente, a variação do lucro integrado da relação entre fornecedor e comprador, decidiu-se manter esta estrutura, suas categorias e subcategorias, reconhecendo o lucro integrado como incidente crítico para a proposição do questionário. A escolha do lucro integrado como incidente crítico permite a aplicação desta técnica e reforça a ligação entre coleta e análise, pois a análise, em última instância, também será baseada na variação do lucro integrado da relação entre usinas e distribuidoras ${ }^{58}$.

Vale esclarecer que nesta proposição, o incidente em destaque, o incidente crítico, é a variação do lucro integrado. Não se deve confundir este incidente com os incidentes que serão tomados como dados do experimento, conforme já citado, fatos objetivos e explicações sobre o funcionamento do setor conforme relato dos entrevistados.

A escolha do modelo teórico de Bogetoft e Olesen (2004) para estruturar o questionário confere mais um atrativo à coleta. Este modelo tem como característica a abordagem holística, o que irá garantir que as questões abordem todos os aspectos necessários a uma análise pelo método da Grounded Theory.

O roteiro final do questionário, conforme foi produzido e aplicado, encontra-se disponível no Apêndice I.

\subsubsection{Sistemática da entrevista}

Conforme colocado anteriormente na seção 6.2.2, na Grounded Theory a categorização é uma das partes fundamentais do processo de pesquisa (BANDEIRA-DE-MELLO, 2007; COLLIS;

\footnotetext{
${ }^{58}$ Este ponto será abordado de maneira apropriada na próxima seção.
} 
HUSSEY, 2005; GLASER; STRAUSS, 1967; STRAUSS; CORBIN, 1990). A categorização compreende a proposição (criação) de categorias e sub-categorias, e a classificação dos dados nestas categorias. No caso desta pesquisa, ao se adotar o modelo de Bogetoft e Olesen (2004) para estruturar a coleta e a análise, suprimiu-se a proposição de categorias.

A seguir, será apresentado um quadro contendo a proposta de sistemática adotada para as entrevistas. Esta proposta foi formulada baseando-se nos conceitos da metodologia de Grounded Theory expostos na seção anterior.

O Quadro 4 apresenta duas colunas. A coluna da esquerda traz as etapas do processo de entrevista. A coluna da direita traz algumas práticas que foram estabelecidas como conduta frente a algumas situações com potencial para causar viés, já esperadas.

Vale esclarecer que o termo constructo utilizado neste quadro também se refere às apreciações dos agentes sobre "como as coisas funcionam" 59 ".

\footnotetext{
${ }^{59}$ Este conceito de dado já foi anteriormente apresentado na seção 6.1.3
} 
Quadro 4: Etapas do processo de entrevista

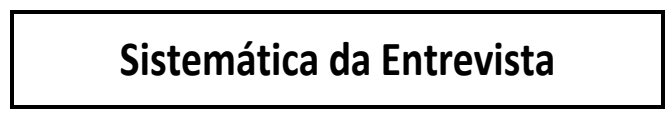

\begin{tabular}{|c|c|}
\hline Escolha do Entrevistado (Alvo) & \\
\hline Escolha de 10 Questões & 1 \\
& \\
\hline
\end{tabular}

\begin{tabular}{|c|c|}
\hline Contato/Agendamento & \multirow{2}{*}{2} \\
\hline Envio das Questões & \\
\hline
\end{tabular}

\begin{tabular}{|c|c|c|}
\hline \multicolumn{2}{|c|}{ A ENTREVISTA } & \multirow{3}{*}{3} \\
\cline { 1 - 2 } P. Exploratória & $\begin{array}{c}\text { Busca por incidentes } \\
\text { desconhecidos }\end{array}$ & \\
\hline P. Explicativa & Classificação dos incidentes & \\
\hline P. Causal & $\begin{array}{c}\text { Busca por validação } \\
\text { (comparação) da ocorrência } \\
\text { dos incidentes }\end{array}$ & \\
\hline
\end{tabular}

\begin{tabular}{|l|l|}
\hline Transcrição da gravação por PQ-1 & 4 \\
\hline
\end{tabular}

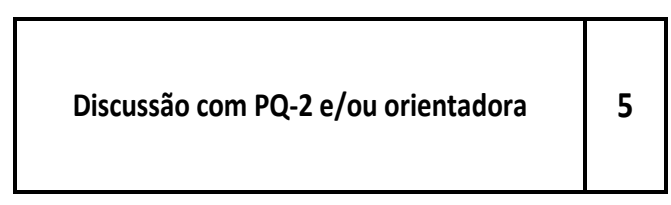

\begin{tabular}{|c|c|}
\hline $\begin{array}{c}\text { Esclarecimento das dúvidas sobre a entrevista } \\
\text { com o agente. }\end{array}$ & 6 \\
\hline
\end{tabular}

\begin{tabular}{|l|l|}
\hline Validação do texto final com o agente & 7 \\
\hline
\end{tabular}

\begin{tabular}{|c|c|}
\hline $\begin{array}{c}\text { Reestruturação do questionário, absorvendo o o } \\
\text { resultado da entrevista }\end{array}$ & 8 \\
\hline
\end{tabular}

\section{Pressupostos}

Assumiu-se que, em princípio, os agentes deveriam ser selecionados da Lista (população), mas, admitindo possíveis contatos com agentes não listados desde o início. Além disso, a escolha do "próximo" alvo também deveria ser influenciada pelo resdultado da "última" entrevista.

Assumiu-se que seria disponibilizado o tempo necessário para conseguir as entrevistas (3 meses), supondo de antemão que seria encontrada uma certa dificuldade para agendá-las com os agentes

Foi assumido que, apesar do potencial viés, seriam aceitas entrevistas for telefone e presenciais; assumiu-se tb que, na medida do possível, ou seja, incorporando o viés dessa opção, um segundo pesquisador (PQ-2) iria acompanhar as entrevistas; assumiu-se que, se possivel, as entrevistas deveriam ser gravadas, mas, se não fosse possivel, tb seriam consideradas.

Assumiu-se que somente PQ-1 (primeiro pesquisador - 0 mestrando) iria transcrever todas as entrevistas

Apesar de gerar viés, assumiu-se que a discussão em grupo poderia contar com PQ-2 e /ou orientadora. Também resolveu-se que seria aceita entrevista que não tivesse sido discutida em grupo

Assumiu-se que este procedimento poderia ser feito pessoalmente, por telefone ou por e-mail, apesar do viés.

Assumiu-se que este procedimento deveria ser feito por escrito.

FONTE: Elaborado pelo autor baseado em Bandeira-De-Mello (2007); Collis e Hussey (2005); Glaser e Strauss (1967); Strauss e Corbin (1990) 


\subsection{Método de análise}

Conforme o conteúdo colocado nos últimos três capítulos, muito já foi dito sobre o método de análise da Grounded Theory. Para complementar o entendimento desta questão, esta seção irá abordar a análise dos dados como o fruto de dois processos. O primeiro deles seria o processo micro analítico, referente ao processo crítico da comparação sistemática dos dados. O segundo deles seria o processo macro analítico, referente à proposição de um teoria substantiva composta pelas várias microteorias aprovadas.

\subsubsection{Micro análise}

Para compreender o processo micro analítico será abordado de forma mais detalhada a concomitância do pensamento crítico indutivo e dedutivo, característico dessa metodologia.

A dedução ocorre ao se classificar ${ }^{60}$ e comparar dados.

A indução ocorre quando se propõe uma microteoria, quando se propõe um caminho (conduta) para validar uma informação por comparação e quando se propõe questões que ampliem o entendimento de um determinado fato.

A Figura 11 apresentado a seguir. mostra a indissociabilidade entre a análise e a coleta de dados, evidenciando as etapas do processo de entrevista adotado nesta pesquisa que não podem ser concluídas caso não ocorra a análise de dados necessária.

\footnotetext{
${ }^{60}$ Conforme explicado anteriormente na seção 6.2.1, nesta pesquisa, adotando-se o modelo teórico de Bogetoft e Olesen (2004) para estruturar a coleta, não é necessário criar categorias nem sub-categorias, apenas classificar os dados de acordo com o modelo.
} 


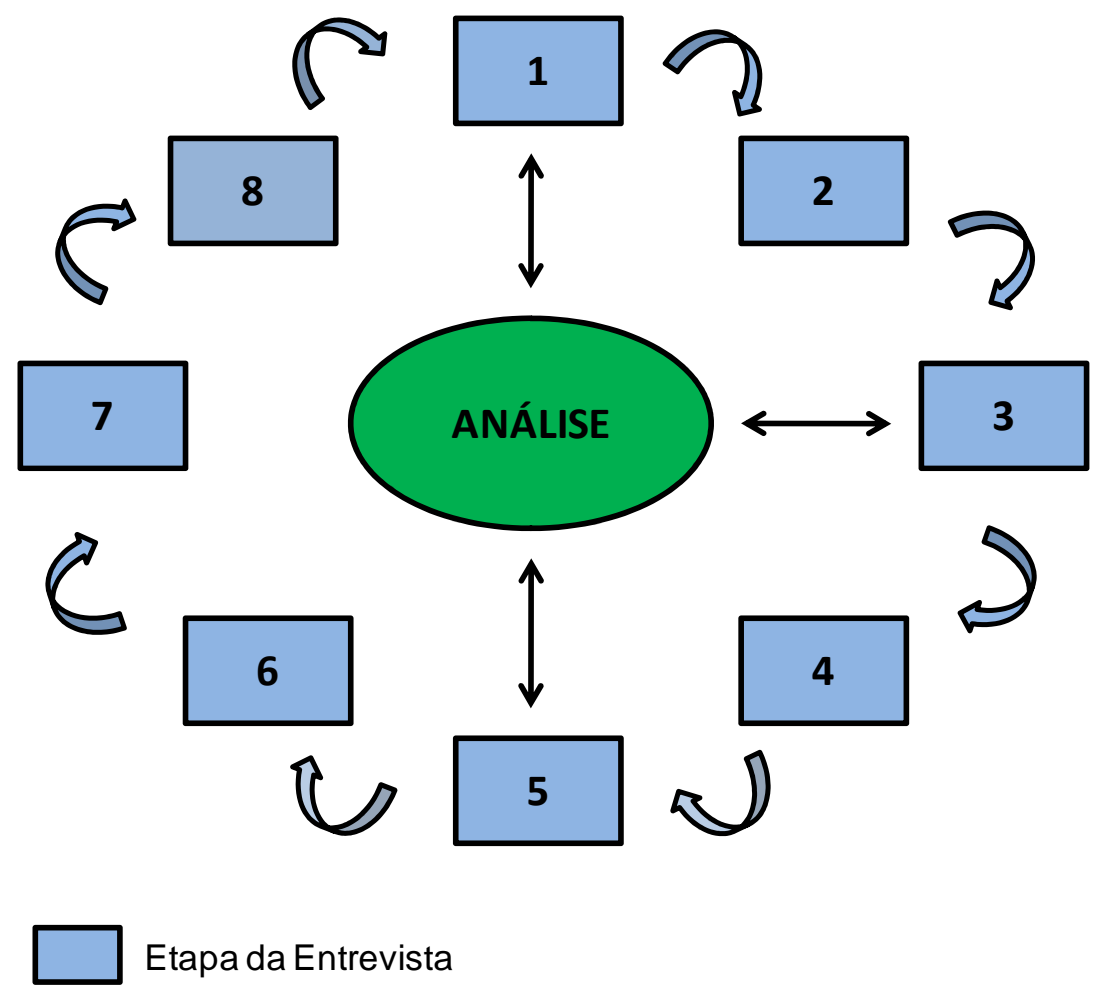

Figura 11: Indissociabilidade entre coleta e análise

FONTE: Elaborado pelo autor baseado em Bandeira-De-Mello (2007); Collis e Hussey (2005); Glaser e Strauss (1967); Strauss e Corbin (1990)

Conforme a Figura 11, a proposta de sistemática da entrevista tem 3 das 8 etapas associadas à análise. Na primeira etapa, o pensamento é indutivo, na terceira e na quinta etapa ocorre tanto indução como dedução.

\subsubsection{Macro análise}

O processo macro analítico é eminentemente indutivo e consiste na proposição de uma teoria substantiva composta pelas microteorias que foram sendo validadas durante a pesquisa. Neste caso, o modelo teórico de Bogetoft e Olesen irá coordenar esta proposição final, enquanto sua estrutura serve como guia para que sejam acomodadas as micro teorias que irão compor o produto final da análise.

Vale lembrar que, de acordo com os capítulos 2 e 3, o pensamento crítico do modelo teórico de Bogetoft e Olesen está relacionado com a ECT da seguinte forma: espera-se que a opção de governança feita efetivamente pelos agentes tenha o menor custo de transação possível (ECT) e, ao mesmo tempo, o maior lucro integrado possível. 
A Figura 12 apresentado a seguir, aborda a sistemática da pesquisa de forma mais ampla. Neste quadro estão representados os dois processos de análise, o macro analítico e sua função coordenadora do modelo teórico de Bogetoft e Olesen para a proposição da teoria substantiva (constructo final), e o micro analítico evidenciando o processo de propor e checar dados sistematicamente até sua aprovação final.

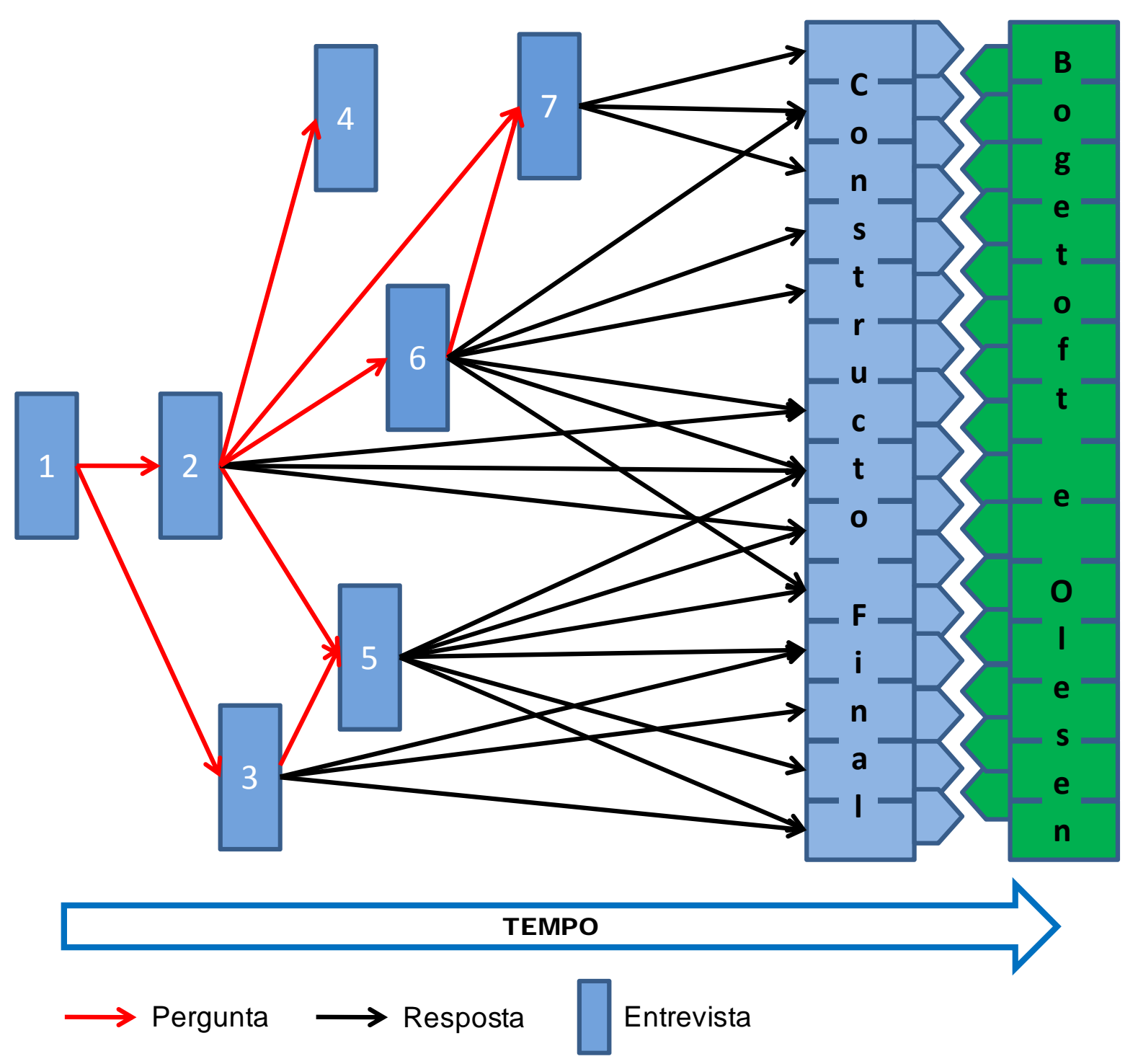

Figura 12: A sistemática da pesquisa

FONTE: Elaborado pelo autor baseado em Bandeira-de-Mello (2007); Collis e Hussey (2005); Glaser e Strauss (1967); Strauss e Corbin (1990) 


\section{A COMERCIALIZAÇÃO DE ETANOL CARBURANTE NO CENTRO-SUL DO \\ BRASIL}

Collis e Hussey (2005) indicam a necessidade de três partes para compor a apresentação dos resultados de uma análise qualitativa: reduzir, estruturar e apresentar graficamente o conteúdo coletado e analisado. A apresentação dos resultados neste capítulo seguirá este modelo proposto pelos autores (op. cit.). O conteúdo reduzido será apresentado em formato dissertativo e as formas estruturada e gráfica serão apresentadas a partir da discussão individual de cada um dos 14 pontos do modelo de Bogetoft e Olesen (2004).

As três formas são complementares. O texto permite compreender de modo mais amplo a comercialização do etanol e introduz varias informações e conceitos que serão utilizados na discussão estruturada. A elaboração dos resultados de forma estruturada, utilizando o modelo teórico, traz rigor à análise evidenciando a relevância de cada um dos determinantes à tomada de decisão final pelos agentes. Por fim, partindo das colocações estruturadas sobre o modelo de Bogetoft e Olesen (2004), será possível apresentar o resultado da pesquisa em um único quadro.

O conteúdo em formato de texto será disposto em quatro seções, da seção 7.2 à 7.5.

A primeira delas, a seção 7.2 será voltada a uma apresentação descritiva do setor, abordando questões ligadas à governança e sua íntima relação com o valor de frete e à posição logística de cada agente. Este conteúdo complementa o trabalho com informações não encontradas durante a reunião das informações referenciais. Esta seção representa, em sua maior parte, o resultado obtido em relação à natureza exploratória e descritiva da pesquisa.

As seções 7.3 e 7.4 têm uma natureza predominantemente causal e tratam das estratégias das usinas e distribuidoras, salientando os determinantes da opção destes agentes por certa estrutura de governança 
A seção 7.5, última seção em formato de texto, tem natureza tríplice ${ }^{61}$ e aborda a influência do ambiente institucional sobre a comercialização do etanol como justificativa para as diferenças de governança entre a comercialização de hidratado e anidro.

A seção 7.6 irá apresentar o conteúdo dos resultados utilizando a estrutura do modelo de teórico de Bogetoft e Olesen (2004), discutindo cada um dos 14 pontos separadamente e finalizando com a apresentação de um quadro geral destes resultados.

Antes de iniciar a apresentação de resultados, na seção 7.1, serão colocados alguns comentários sobre a execução das entrevistas sob a ótica metodológica para que os resultados apresentados em seqüência sejam mais bem compreendidos.

\subsection{Comentários sobre a execução das entrevistas sob a ótica metodológica.}

Durante o decorrer das entrevistas a questão da confidencialidade foi mais problemática do que se esperava. Além dos agentes não quererem tornar público qualquer dado quantitativo, a maioria deles preferia que o conteúdo das entrevistas não fosse vinculado aos seus nomes e principalmente às empresas em que trabalhavam.

Além dos agentes não se sentirem à vontade com que este trabalho viesse a publicar seus comentários sobre determinados assuntos, o uso do nome de qualquer empresa como referência às informações não poderia ocorrer sem autorização prévia das próprias empresas.

Devido a esta situação, resolveu-se não apontar qualquer nome de entrevistado no texto, nem fazer uma referência direta aos cargos que ocupavam nas empresas do setor.

Esta opção viabilizou a pesquisa, porém amplificou as características de confiabilidade ${ }^{62}$ e validade $^{63}$ já discutidas no capítulo 5, seção 5.2.2. À medida que esta posição foi estabelecida e os entrevistados passaram a ser informados que não haveria divulgação de nomes, cargos e organizações, as entrevistas passaram a ser mais produtivas e ricas em conteúdo, aumentando

\footnotetext{
${ }^{61}$ Conforme explicado anteriormente no capítulo 5, seção 5.2, a natureza tríplice denota características exploratórias, explicativas e causais.

${ }^{62} \mathrm{O}$ Conceito de Confiabilidade refere-se à capacidade que uma pesquisa tem de ser replicável (COLLIS e HUSSEY, 2005)

${ }^{63}$ Para Collis e Hussey (2005, p.64), o Conceito de Validade "refere-se a até que ponto as descobertas da pesquisa representam de maneira precisa o que está realmente acontecendo” numa determinada situação.
} 
a validade dos resultados. Enquanto isso, o anonimato das declarações diminuiu a possibilidade de replicação destes resultados.

Vale esclarecer que o Grupo Moema autorizou a divulgação de alguns dados quantitativos da empresa, assim como o conteúdo das entrevistas que foram realizadas com seus executivos. Os dados quantitativos serão apresentados na seção 7.6.3 deste capítulo, mas, para manter a conformidade com o conteúdo coletado com os demais agentes entrevistados, também não será feita referência a nomes e cargos.

\subsubsection{Descrição das entrevistas}

Foram realizadas vinte e duas entrevistas, sendo duas no primeiro semestre de 2007 e vinte no primeiro semestre de 2008.

As entrevistas abordaram vinte e um executivos diferentes, todos ligados à área de comercialização de etanol, representando dezesseis organizações do setor. Alguns executivos foram entrevistados mais de uma vez e algumas entrevistas foram feitas com mais de um executivo da mesma organização. Entre os executivos, dezessete ocupavam cargos entre média e alta gerência, e quatro eram analistas.

Entre os cinco grupos de comercialização, que representam 51,5\% de todo etanol comercializado $^{64}$, foram entrevistados representantes de quatro deles. Entre as distribuidoras, foram entrevistados executivos de três integrantes do Sindicom, associação formada por apenas dez distribuidoras que detêm, em 2008, 68\% da distribuição de etanol e 87\% da gasolina C (SINDICOM, 2008). Além das distribuidoras do Sindicom, também foi contatada uma distribuidora emergente.

\footnotetext{
${ }^{64}$ Conforme estimativa apresentada no Capítulo 4, na Tabela 6
} 
O Quadro 5 apresentado a seguir, aponta a quantidade e os tipos de organizações cujos executivos foram entrevistados.

Quadro 5: Tipos de organizações representadas nas entrevistas

\begin{tabular}{|l|l|}
\hline \multicolumn{2}{|c|}{ Organizações } \\
\hline Grupos de comercialização de etanol & 4 \\
\hline Distribuidoras de combustível associadas ao Sindicom & 3 \\
\hline Organizaçães setorias (UNICA e SINDICOM) & 1 \\
\hline Trading Company de atuação nacional e internacional & 1 \\
\hline Distribuidora de combustível emergente & 1 \\
\hline $\begin{array}{l}\text { Grupos industriais usineiros que escoam apenas parte de sua produção de } \\
\text { etanol através de grupos de comercialização }\end{array}$ & 4 \\
\hline $\begin{array}{l}\text { Grupo industrial usineiro que escoa toda sua produção de etanol através } \\
\text { de grupo de comercialização }\end{array}$ & 1 \\
\hline Consultoria Comercial & 1 \\
\hline \multicolumn{1}{|c|}{ Total } & $\mathbf{1 6}$ \\
\hline
\end{tabular}

FONTE: Elaborado pelo autor com base nas entrevistas

Vale comentar que o processo de amostragem teórica acabou mostrando que não havia necessidade de entrevistar representantes do governo nem distinguir usinas pertencentes a pequenos ou grandes grupos industriais, conforme a proposta inicial de população apresentada no quadro 3, na seção 6.3. Por outro lado, este processo de amostragem apontou a necessidade de abordar usinas que comercializassem toda sua produção por meio de grupos de comercialização e outras que fizessem isto parcialmente.

Com relação à ausência da representação de uma das duas organizações setoriais que se pretendia entrevistar, infelizmente não houve interesse por parte de uma delas em participar da pesquisa.

Conforme colocado no início deste capítulo, as próximas quatro seções serão dedicadas a apresentar o conteúdo dos resultados em forma de texto. À medida que o conteúdo for sendo colocado, serão feitas as referências pertinentes à origem das informações. 


\subsection{Governança e logística}

Esta seção aborda de forma descritiva a governança do setor, apresentando informações necessárias para dar base às discussões das próximas seções. Além de descrever a governança do setor e detalhar o modelo do contrato observado, será feita uma apresentação de como se dá a valoração do frete na comercialização do etanol devido ao peso deste item na formação de preço final do produto, conforme será explicado a seguir.

\subsubsection{A estrutura de governança do setor}

As três estruturas básicas de governança: mercado, contratos e integração vertical, puderam ser encontradas nas relações estudadas.

Foi observado um único caso de integração vertical. Esse caso, extremamente recente, é o da movimentação de integração para frente feito pela Cosan, maior produtora de etanol brasileiro, sobre a operação de distribuição de combustíveis da Esso, quarta maior distribuidora de combustíveis do país, subsidiária da multinacional Exxon-Mobil. Tal fato ocorreu no fim do mês de abril de 2008, enquanto estavam sendo conduzidas as entrevistas desta dissertação. Neste momento, apesar da compra estar sendo anunciada, as empresas ainda operavam independentemente.

A comercialização por meio do mercado spot é observada tanto para o anidro com para o hidratado, sendo que é mais freqüente no mercado de hidratado.

O mercado spot é responsável por, aproximadamente, 20\% a 30\% do volume de anidro e $60 \%$ a $70 \%$ do volume de hidratado comercializados com destino ao mercado interno brasileiro. Conseqüentemente, os contratos são observados na comercialização de $70 \%$ a $80 \%$ do anidro e apenas em $30 \%$ a $40 \%$ do hidratado.

De acordo com estas estimativas, percebe-se a relevância da contratação como governança nesta transação. Nas próximas duas seções, serão abordados os detalhes deste tipo de contrato, e um dos pontos fundamentais em sua negociação, o diferencial logístico de cada usina em relação às bases de distribuição de combustíveis. 


\subsubsection{O diferencial logístico}

O valor do frete entre uma usina e uma base de distribuição tem um impacto direto sobre o preço final negociado entre os agentes. O etanol é uma commodity, um produto praticamente indiferenciado, sendo produzido sob a vigência de uma tecnologia amplamente disponível. Sendo assim, o diferencial logístico passa a ser um atributo relevante na composição do preço de uma transação, devido à sua singularidade e ao peso que confere ao preço do produto final. De acordo com a Sincopetro (2007), o frete das usinas às distribuidoras é responsável por, aproximadamente, 4,4\% do valor transacionado, no Estado de São Paulo. Para Xavier (2008), considerando todo o território nacional, esse valor chegaria a 5,9\%.

Como comentado no capítulo 4, o Estado de São Paulo é o maior produtor de etanol do país, respondendo por 59,44\% da total produzido no centro-sul na safra 2006/07, conforme apresentado anteriormente na Tabela 4. Conforme a Figura 13 apresentada a seguir, pode-se ver que a produção está concentrada na região oeste do estado, e a maioria das usinas que estão fora do estado também mantém proximidade a esta região.

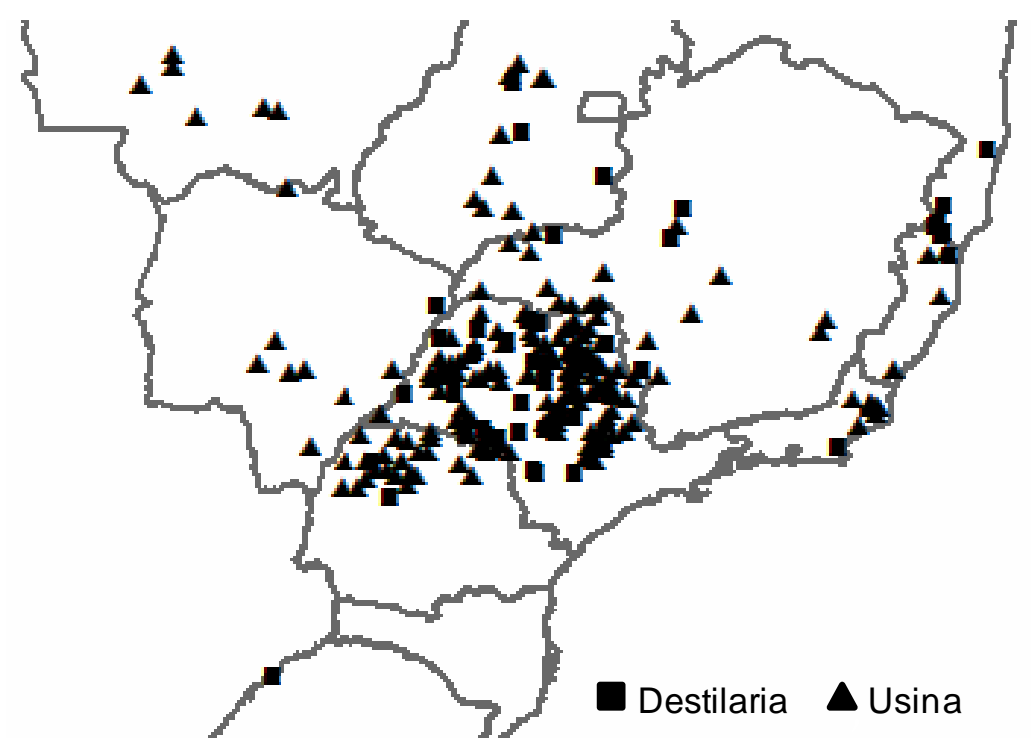

Figura 13: Disposição geográfica das usinas no centro-sul do Brasil FONTE: Núcleo Interdisciplinar de Pesquisa Energética (2005)

O consumo do produto está concentrado nos grandes centros urbanos, como a cidade de São Paulo. Além do etanol fluir da área produtiva para onde será consumido, uma parte é exportada através do litoral paulista, principalmente pelo Porto de Santos. Sendo assim, o 
fluxo básico de escoamento para o produto acaba sendo do interior do estado de São Paulo para a capital, como mostra a Figura 14.

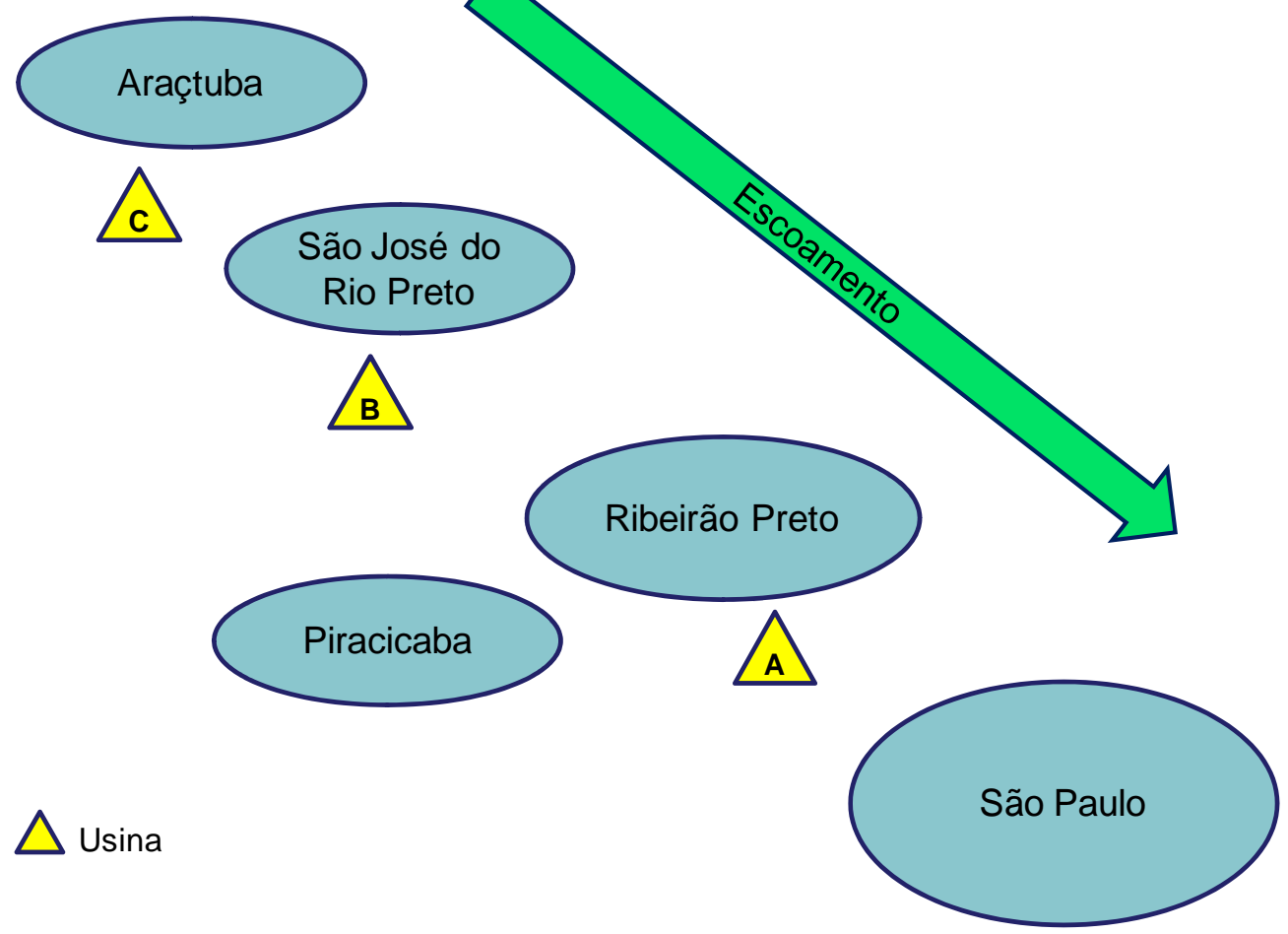

Figura 14: O diferencial logístico

FONTE: Elaborado pelo Autor com base nas entrevistas

No jargão do mercado, diz-se que o etanol “desce”, ou seja, parte da produção das usinas abastece os mercados locais, das cidades mais próximas à elas, e o restante é enviado a grandes centros consumidores, seguindo o sentido do noroeste ao sudeste paulista. O maior centro consumidor é o mercado paulistano e a partir de São Paulo o etanol é enviado ao Rio de Janeiro e ao Porto de Santos.

De acordo com essa dinâmica, será sempre mais caro enviar etanol para a cidade de São Paulo quanto mais distante uma usina estiver deste ponto. Convencionou-se chamar a posição em Ribeirão Preto de "Frete Zero", devido à sua proximidade da cidade de São Paulo e sua grande capacidade produtiva. Dessa forma, como se pode acompanhar no exemplo da Figura 14, o frete da região de Araçatuba, onde se encontra a Usina C, é positivo e maior que o frete de São José do Rio Preto, onde se encontra a Usina B. O frete da região onde está localizada a Usina A é considerado negativo, pois está além de Ribeirão Preto em direção a São Paulo. 
As informações e considerações sobre o diferencial logístico do setor foram obtidas nas entrevistas com os executivos das distribuidoras, dos grupos de comercialização e das usinas.

\subsubsection{O contrato adotado no centro-sul}

Os contratos de abastecimento de etanol, tanto anidro como hidratado, têm um perfil bastante padronizado, ou seja, variam muito pouco em conteúdo, quando adotados por diferentes agentes.

O contrato estabelece um determinado volume de etanol a ser comercializado, uma frequência de entrega, um período de vigência e um “forma” de se calcular o preço, que, na prática, deverá ser derivado do indicador Esalq ${ }^{65}$.

Basicamente todos os entrevistados consultados sobre este assunto foram unânimes na descrição geral do contrato, tanto os executivos do lado da produção como os do lado da distribuição. Em uma das entrevistas, um usineiro permitiu ao entrevistador acesso direto a um de seus contratos com uma das distribuidoras do Sindicom.

De maneira geral, a vigência dos contratos é de 1 a 2 anos, sendo atrelados ao ano-safra ou ao ano civil. Apesar de existirem contratos de até 3 anos, a compreensão das entrevistas foi de que os contratos são efetivamente desenhados para 1 ano, tendo cláusulas que permitem a sua renovação. Na prática, o horizonte deste contrato é 1 ano.

O contrato estipula um volume a ser comercializado mensalmente entre as partes. Este volume mensal deve ter suas retiradas acordadas de alguma forma, sendo as mais comuns as retiradas semanais ou quinzenais. Apesar do estabelecimento de um cronograma de retiradas, geralmente existe algum mecanismo contratual, alguma cláusula, que permite flexibilizar as datas dentro do mês ${ }^{66}$, para que, no mês em questão, os agentes tenham a possibilidade de ajustar as datas às suas necessidades do momento.

\footnotetext{
${ }^{65}$ O Cepea (Centro de Estudos Avançados em Economia Aplicada) calcula e divulga um indicar de preço para o hidratado e para o anidro. Este centro oferece dois indicadores por produto para região do Estado de São Paulo: um semanal e outro mensal. Estes indicadores referem-se à ponderação das consultas feitas nesta região sobre os preços referentes aos negócios efetivamente concluídos entre usinas e distribuidoras, no mercado spot, neste momento.

${ }^{66}$ Este ponto será retomado e discutido em detalhes na seção 7.3.1.2
} 
O preço é estabelecido a partir do indicador Esalq, sendo o resultado de um eventual desconto ou acréscimo ao valor do indicador do momento da retirada. Quando existe desconto sobre o indicador, o contrato é chamado ESALQ negativo e quando é negociado um acréscimo, é chamado ESALQ positivo. O desconto, ou o prêmio, é equacionado de duas maneiras básicas: como uma porcentagem do indicador ou como um valor fixo. Também existem algumas variações no que diz respeito à escolha do indicador Esalq, podendo ser um contrato fechado com o indicador da própria semana da transação, da semana anterior à transação ou alguma outra composição métrica à data da transação.

O diferencial logístico de cada usina impacta diretamente no resultado das negociações de desconto com as distribuidoras ${ }^{67}$.

No exemplo da Figura 14, pode-se esperar que uma distribuidora com base em São Paulo poderia fechar contrato com a Usina A no valor referente ao indicador Esalq, com a Usina B em ESALQ menos 1\%, e com a Usina C em ESALQ menos 2\%.

Como dito anteriormente, valores fixos também podem compor o equacionamento do preço. Voltando ao exemplo, essa mesma distribuidora poderia fechar com a Usina A no valor referente ao indicador Esalq, com a Usina B em ESALQ menos 1\%, e com a Usina C em ESALQ menos $1 \%$ menos R $\$ 50,00$.

A intenção aqui é deixar claro a relevância do diferencial logístico no modelo básico de construção deste contrato, em que o preço é sempre calculado ex-post ao momento da contratação.

Além desse contrato formal, que acabou de ser descrito, também existem agentes que se utilizam de contratos informais, caracterizados pela inexistência de formalidade jurídica. No caso dos contratos informais, existe um compromisso dos agentes em manter a comercialização ativa, na qual eles chegam a combinar um volume a ser transacionado em determinado período. Quanto ao preço, o racional segue o mesmo padrão do contrato formal, ou seja, negociar um valor que reflita o valor médio do mercado spot no momento da transação. Durante as entrevistas estimou-se que 20\% dos contratos seguem esta opção.

\footnotetext{
${ }^{67}$ Além do diferencial logístico, a negociação depende do poder de barganha de cada agente. A discussão completa da dinâmica desta negociação será apresentada, ainda neste capítulo, nas seções 7.3.1.1, 7.3.1.2 e 7.3.2
} 


\title{
7.3 A estratégia das distribuidoras
}

\author{
"Veja bem, antes de mais nada, você tem que saber \\ que o negócio de distribuição de combustíveis \\ é um negócio de ponto de venda...”
}

\begin{abstract}
Frase dita por um executivo que esteve por 3 anos à frente do gerenciamento de compras de etanol para uma distribuidora de grande porte, integrante do Sindicom, ao ser colocada a questão referente à motivação das distribuidoras ao uso de contratos.
\end{abstract}

A estratégia principal das grandes distribuidoras é focar a atenção no número de pontos de venda para seus produtos. O maior determinante do sucesso no negócio de distribuição é a capacidade de cada agente manter e ganhar pontos de venda, o que influencia diretamente sua capacidade de conquistar e atender determinada fatia do mercado em questão.

Sem dúvida, existem ações para criar diferenciação no serviço e até no produto final. Postos de abastecimento oferecem serviços de conveniência e algumas distribuidoras tentam capturar a fidelidade de seus clientes oferecendo um produto mais seguro, livre de contaminações e de diferentes qualidades e preços. Apesar destas ações de marketing serem importantes, o ponto central da estratégia ainda é o número de pontos de venda atendido pela distribuidora.

No mercado de combustíveis líquidos de varejo, ou seja, no mercado da venda de combustível dos postos de abastecimento ao usuário final, percebe-se que o consumidor não deixa de usar seu veículo facilmente frente a um aumento de preço. Mesmo com a introdução do carro flex, o consumidor pode até mudar de combustível, mas continuará usando seu automóvel, pelo menos no curto prazo. Tal fato tem um enorme impacto sobre o posicionamento estratégico da distribuidora, que, preocupada com seu número de postos, passa a não se preocupar tanto com o preço final do produto na bomba, contanto que o preço de seus produtos seja competitivo frente ao de suas concorrentes.

Detalhando um pouco mais a questão da concorrência entre as distribuidoras, cuja estrutura foi caracterizada no capítulo 4 como um oligopsônio com franja competitiva no relacionamento destes agentes com as usinas, entendeu-se que as distribuidoras concorrem 
entre si fortemente. Os quatro executivos das distribuidoras entrevistados confirmaram esta colocação.

A partir das apreciações destes executivos e do consultor entrevistado, pôde-se visualizar um cenário em que as distribuidoras do Sindicom concorrem entre si fortemente, e as pequenas distribuidoras também concorrem entre si e com as distribuidoras do Sindicom ${ }^{68}$ nessa mesma intensidade.

A competição entre as grandes distribuidoras se concentra na preocupação em oferecer a seus franqueados, os donos dos postos de abastecimento, uma condição igual ou melhor que as distribuidoras concorrentes estão oferecendo em termos do preço do combustível a ser revendido. Quanto menor o preço ofertado da distribuidora a seus postos, maior a margem de lucro que os postos poderão exercer ao revendê-lo. Se uma distribuidora não consegue ser competitiva neste ponto, seu franqueado perde o interesse em trabalhar com sua bandeira e, provavelmente, irá procurar outra bandeira mais lucrativa para representar, acarretando uma perda no número de pontos de venda para sua distribuidora de origem.

A grande distribuidora não precisa necessariamente comprar combustível a preços baixos para ter sucesso, mas precisa comprar tão bem, ou melhor, que suas concorrentes. Qualquer melhoria na posição frente à concorrência faz diferença. Dessa forma, compreende-se que a compra, em si, passa a ser estratégica. O negócio de distribuição é um negócio de altos volumes e baixas margens, enxuto, sendo assim, as distribuidoras se esforçam muito para comprar o combustível em condições de preço adequadas para garantir a competitividade do franqueado e mantê-lo interessado em continuar trabalhando sob a bandeira da distribuidora.

As pequenas distribuidoras têm uma estratégia diferente, elas dedicam seu esforço ao atendimento dos postos bandeira branca, focando apenas no curto prazo, tentando preencher o espaço não ocupado pelas grandes. Elas não fazem contratos com as usinas, adquirindo todo o etanol que comercializam no mercado spot.

As distribuidoras pequenas tentam ser competitivas montando operações enxutas e flexíveis, para oferecer um preço melhor que suas concorrentes ao mercado, desta forma não seria

\footnotetext{
${ }^{68}$ Como será visto neste mesmo capítulo, nem sempre as pequenas distribuidoras competem diretamente com as grandes. Quando isso ocorre, a competição é acirrada.
} 
possível a estas distribuidoras oferecerem toda essa agilidade e flexibilidade se estivessem atreladas a contratos com alguma usina.

\subsubsection{A política de compras de etanol das grandes distribuidoras}

O objetivo de comprar bem frente à concorrência faz com que as distribuidoras tomem a seguinte posição: em primeiro lugar, buscar avidamente o melhor preço e as melhores condições de compra, em segundo, ter cautela em relação ao horizonte temporal dessa compra evitando assumir posições antecipadamente. As distribuidoras são avessas ao risco ${ }^{69}$ quando estabelecem suas políticas de compras, elas não têm a intenção de se comprometerem com compras antecipadas em condições pré-estabelecidas por medo de que possam perder competitividade frente às suas concorrentes num futuro próximo, devido a qualquer eventual mudança no ambiente competitivo. Na prática, as distribuidoras tentam comprar bem, e comprar apenas para as suas necessidades de curto prazo.

Esse comportamento de compras focado no curto prazo passou a ser chamado, no jargão do mercado, de compra “da mão para a boca”. Tal fenômeno ajuda a entender a motivação das distribuidoras frente aos contratos.

Quando a distribuidora se volta a seus fornecedores para adquirir o etanol, ela percebe que o ponto fundamental para o sucesso de sua estratégia de compras está no estabelecimento de uma boa operação logística. O custo do frete, discutido anteriormente na seção 7.2.2, tem grande impacto sobre a condição final de preço oferecido pelas usinas às distribuidoras. Sendo assim a distribuidora percebe que é imperativo estabelecer um programa de gerenciamento logístico ótimo para maximizar o resultado de suas compras.

Para comprar de forma econômica, a distribuidora leva em conta alguns pontos. O diferencial logístico, abordado anteriormente na seção 7.2.2, é o principal deles. Quanto mais longe, mais caro será para retirar o etanol em uma usina. A segunda preocupação é estabelecer uma programação de retirada capaz de maximizar a utilização de sua frota de caminhões, ou de uma frota contratada de terceiros, sendo que, para estabelecer uma programação, é necessário saber quando e onde serão feitas as retiradas.

\footnotetext{
${ }^{69}$ Todos os executivos representantes das distribuidoras tiveram a mesma posição quanto à colocação de que as distribuidoras são avessas ao risco nesta operação.
} 
Além da programação da frota por si só exigir conhecimento prévio de destino, um outro fator acrescenta mais peso a essa necessidade. No mercado de combustíveis o peso de harmonizar a logística do etanol com a logística do diesel é bastante relevante. Se uma distribuidora consegue trazer o etanol das usinas no frete de retorno da entrega de diesel, sua economia logística de frota fica otimizada. A implantação de tal procedimento, de frete casado dieseletanol, aumenta mais ainda a necessidade de saber com antecedência a programação de retirada do etanol.

Não é possível gerenciar uma frota de caminhões retirando etanol por todo território nacional de forma econômica, sem um mínimo de programação prévia. Desta forma, a distribuidora tem que escolher um ponto ótimo quanto ao compromisso temporal que gostaria de assumir, equacionando duas forças opostas, por um lado querendo comprar com menor horizonte possível para evitar o risco de perder competitividade frente à suas concorrentes, por outro, se vendo forçada a fechar posições antecipadamente para usar de forma econômica sua frota.

O contrato, no formato descrito anteriormente (seção 7.2.3), está de acordo com a necessidade da distribuidora. Ele estabelece um compromisso entre distribuidora e usina que permite à distribuidora saber antecipadamente o volume disponível a ser retirado num certo local, e, como o preço é indexado ao indicador Esalq do momento da retirada, não ocorre uma tomada de posição prévia em relação a um preço futuro preestabelecido. Portanto, a motivação da distribuidora ao uso de contratos fica definida pela necessidade de exercer eficientemente sua política de compras.

Um dos gerentes de compra de etanol chegou a dizer que a questão logística, apesar de ser importantíssima, é tão complexa e de difícil avaliação que chega a ser mal interpretada até por alguns executivos das próprias distribuidoras, acarretando em políticas de compras desalinhadas à estratégia geral das empresas.

Sob a ótica da Economia dos Custos de Transação, esta necessidade de programação prévia de retiradas, com determinação de locais e datas antecipadamente, evidencia a ocorrência de especificidade de ativos temporal e locacional nesta transação.

Usando esta lógica, numa avaliação por parte das distribuidoras, quando o preço final (incluindo o frete) do etanol de duas usinas situadas em diferentes posições geográficas for 
equivalente, a usina cuja posição permitir a formação do melhor arranjo logístico à frota da distribuidora, será mais bem avaliada como fornecedora. Conforme colocado no capítulo 4, seção 4.3.1, na maioria das vezes, as bases das diferentes distribuidoras ficam localizadas nos mesmos pontos, sendo assim, quanto mais bem avaliada for a usina como fornecedora às distribuidoras, menor será sua especificidade locacional.

\subsubsection{O prazo dos contratos como reflexo da política de compras das distribuidoras}

Como foi visto, as distribuidoras dão preferência a contratos de curto prazo para evitar o risco de uma tomada de posição antecipada. O desconto, assim como descrito anteriormente na seção 7.2.3, é o item que gera maior preocupação para a distribuidora.

Contratos de fornecimento de etanol têm cláusulas que suspendem sua vigência perante mudanças bruscas no mercado, como eventuais mudanças institucionais. Dessa forma, além dos volumes e prazos de retirada, apenas o desconto é fixo. A condição básica do mercado, se

ele está comprador ou vendedor, e o poder de barganha individual de cada agente, acabam compondo, junto ao diferencial logístico, o desconto de cada contrato. As distribuidoras preferem assumir esse compromisso, referente ao desconto, apenas pelo curto prazo de um ano, para evitar o risco de adentrar num próximo ano utilizando um desconto desatualizado frente às suas concorrentes.

O desconto praticado costuma variar entre os agentes, mas essa variação acompanha uma certa média. Em certos momentos, essa média se desloca, estabilizando-se num novo patamar. Tal deslocamento é seguido por todos os agentes do mercado ao renegociarem seus contratos, sendo que uma distribuidora “comprada” num contrato de longo prazo não poderia fazer essa movimentação, caindo, inevitavelmente, na desatualização frente às suas concorrentes.

\subsubsection{O contrato como instrumento estratégico de compras}

Da forma como é desenhado, na maioria das vezes, as distribuidoras se comprometem com as usinas com a retirada de um certo volume mensal, muitas vezes se guardando o direito de fazê-lo na data, ou datas, que lhes for mais conveniente, dentro do mês pré-determinado, conforme explicado anteriormente na seção 7.2.3. 
Tal condição permite às distribuidoras fazer uso do contrato, ou seja, usá-lo como instrumento estratégico, exercendo seu direito de compra conforme suas políticas de compras e conforme o mercado naquele exato momento. Se uma distribuidora entende que o momento é de queda nos preços, ela pode ir exercendo o contrato logo no início do mês, poupando-se de comprar no spot ao limite. Dessa forma, ela sai ganhando, pois toda sua compra no spot fica para o final do mês, aproveitando ao máximo a queda dos preços. Além disso, a própria distribuidora contribui para forçar a queda do preço, pois, à medida que segura sua compra no spot, dá uma contribuição para a diminuição da demanda agregada pelo produto, acelerando a baixa dos preços. Apesar do contrato não ter sido criado para ser um instrumento estratégico, ele também acaba tendo essa utilização.

Entre os executivos do lado da produção, o entrevistado ligado à Copersucar foi o mais interessado nesta discussão, deixando claro que autorizava a publicação de suas idéias e posicionamento referente à esta questão.

Desde a safra 2007/08 a Copersucar, representando suas 28 unidades produtoras, passou a não aceitar mais esta condição contratual reivindicada pelas distribuidoras, pois entende que este tipo de acordo não é favorável ao lado da produção.

Sendo a Copersucar o maior grupo de comercialização, seu poder de barganha parece ser suficiente para tomar esta posição frente à distribuição. Este posicionamento passa a ser mais difícil para unidades produtoras menores.

\subsubsection{A opção de governança das distribuidoras}

O Quadro 6 apresentado a seguir, resume o que se observa no mercado quanto à opção das distribuidoras pela estrutura de governança na transação com as usinas. Neste quadro as distribuidoras que não fazem parte do Sindicom foram divididas em pequenas e emergentes, para evidenciar as pequenas distribuidoras (emergentes) que estão aumentando sua participação no mercado, chegando inclusive a fechar contratos com algumas usinas. Apesar 
de estar citado no quadro, deve-se entender que o contrato entre emergentes e usinas existe ${ }^{70}$, porém é deveras incomum.

Os contratos relacionais foram apontados por todos os executivos das distribuidoras entrevistados como uma prática deste mercado.

Quadro 6: A opção de governança das distribuidoras de combustíveis

\begin{tabular}{|c|c|c|c|c|c|c|c|}
\hline \multirow{2}{*}{$\begin{array}{c}\text { Total da } \\
\text { Share }\end{array}$} & \multirow{2}{*}{$\begin{array}{c}\mathrm{N}^{\mathbf{o}} \text { de } \\
\text { Distrib. }\end{array}$} & \multirow{2}{*}{ Agente } & \multirow{2}{*}{$\begin{array}{l}\text { Share de } \\
\text { mercado }\end{array}$} & \multirow{2}{*}{ Spot } & \multicolumn{2}{|c|}{ Contratos } & \multirow{2}{*}{ Integração } \\
\hline & & & & & Relac. & Formais & \\
\hline \multirow{5}{*}{$\begin{array}{c}\text { Sindicom } \\
(53 \%)\end{array}$} & 1 & BR & $17 \%$ & $\mathrm{x}$ & $\mathrm{x}$ & $\mathrm{x}$ & \\
\hline & 1 & Ipiranga & $14 \%$ & $\mathrm{x}$ & $\mathrm{x}$ & $\mathrm{x}$ & \\
\hline & 1 & \begin{tabular}{|l|} 
Shell \\
\end{tabular} & $10 \%$ & $\mathrm{x}$ & $\mathrm{x}$ & $\mathrm{x}$ & \\
\hline & 1 & Texaco & $7 \%$ & $\mathrm{x}$ & $\mathrm{x}$ & $\mathrm{x}$ & \\
\hline & 1 & Esso & $5 \%$ & $\mathrm{x}$ & $\mathrm{x}$ & $\mathrm{x}$ & $\mathrm{x}$ \\
\hline \multirow[b]{2}{*}{$\begin{array}{c}\text { Não } \\
\text { Sindicom } \\
(47 \%)\end{array}$} & \multirow[b]{2}{*}{157} & Emergentes & \multirow[b]{2}{*}{$47 \%$} & $\mathrm{x}$ & $\mathrm{x}$ & $\mathrm{x}$ & \\
\hline & & Pequenas & & $\mathrm{x}$ & & & \\
\hline
\end{tabular}

FONTE: Elaborado pelo autor com base nas entrevistas

Tomando-se como base as colocações e as argumentações desta seção, conclui-se que a governança mista entre contratos e mercado spot é a opção de governança que acomoda da melhor forma os anseios estratégicos das grandes distribuidoras, minimizando os custos de transação inerentes à comercialização do etanol.

O contrato padrão de comercialização de etanol, usando uma precificação flutuante, é um instrumento capaz de coordenar a transação a ponto de oferecer aos agentes uma condição ótima em que os custos de transação, originados principalmente pelas especificidades locacional e temporal dos ativos, serão os menores possíveis. Essa mesma afirmação, sob a óptica sugerida por Bogetoft e Olesen (2004), seria de que este contrato realmente maximiza o lucro integrado da transação envolvendo usinas e distribuidoras de combustíveis.

\footnotetext{
${ }^{70}$ Uma das usinas entrevistadas declarou que tinha contratos com uma distribuidora que não fazia parte do Sindicom. Devido ao poder de barganha entre esta usina, um grande grupo industrial, e a distribuidora ainda emergente, o contrato era ESALQ positivo, ou seja, a usina recebia um prêmio acima do indicador Esalq para garantir o fornecimento a esta distribuidora.
} 
Apesar do contrato promover o efeito de maximizar o resultado da operação logística das distribuidoras, sua melhor utilização não é como forma exclusiva de governança. O ambiente institucional e competitivo deste setor, cria uma situação de riscos e oportunidades em que ainda é vantajoso aos agentes, tanto distribuidoras como usinas, manter uma certa parte de seus negócios no mercado spot. Isto também justifica a opção das pequenas distribuidoras em manter 100\% dos seus negócios no mercado spot.

O caso da integração vertical entre a Cosan e a Esso será discutido na próxima seção.

\subsection{A estratégia das usinas}

As conversas e discussões geradas durante as entrevistas mostram que a estratégia fundamental, comum a todas as unidades produtoras, e de maior força nas tomadas de decisão, é a estratégia de custos. A grande maioria dos executivos das distribuidoras, usinas e grupos de comercialização têm uma visão clara deste fato.

O agronegócio álcool é, antes de mais nada, um negócio de produção industrial, cuja lucratividade está na capacidade da empresa manter seus custos baixos e muito bem gerenciados.

A produção industrial ${ }^{71}$ do etanol caminha atrelada à produção agrícola, e não à área de vendas. A cana tem um peso muito grande sobre os custos de produção do etanol ${ }^{72}$, fazendo com que as peculiaridades de seu ciclo produtivo sejam o centro da coordenação da produção da usina. Para obter um aproveitamento ótimo do canavial, a produção acompanha a programação da colheita da cana ao longo da safra, pois 48 horas após a colheita, a cana se degrada perdendo significativamente sua qualidade para a industrialização (MORAES, 1999; WAAK et al, 1998).

Vale comentar que após iniciada a safra, a margem de manobra do usineiro para redirecionar sua produção entre açúcar e etanol é muito baixa, algo em torno de $10 \%$ do volume total de cana esmagado, o que aumenta ainda mais o efeito do andamento da colheita sobre o da industrialização (RODRIGUES, 2007).

\footnotetext{
${ }^{71} \mathrm{O}$ termo PRODUÇÃO INDUSTRIAL está sendo empregado conforme a classificação adotada no modelo teórico de Bogetoft e Olesen (2004), onde PRODUÇÃO e ESTOCAGEM, juntos, formam o chamado PROCESSO PRODUTIVO

${ }^{72}$ Segundo o Consecana, a cana é responsável por 62,1\% do custo de produção do etanol (CONSECANA, 2006)
} 


\subsubsection{A política de vendas das usinas}

Diante de uma produção industrial atrelada ao andamento da colheita de cana, cada agente irá se preocupar em comercializar da melhor forma possível seu produto, enquanto ele vai sendo produzido $^{73}$, inexoravelmente, de acordo com a safra agrícola.

A seguir, serão colocados os dois fatores indicados pelos entrevistados como os determinantes da política de vendas das usinas: a necessidade de garantir um fluxo de caixa adequado à empresa e a disposição ao risco de cada agente.

Após discutir estes determinantes, será abordado o fenômeno da organização destes agentes em diferentes formas organizacionais visando criar a melhor condição possível para a execução de suas políticas de venda. Como será visto, a organização dos agentes em grupos de comercialização não é um determinante da política de vendas, mas uma conseqüência desta política.

\subsubsection{Garantia de fluxo de caixa}

Houve unanimidade entre os entrevistados ao apontar a necessidade de prever minimamente suas vendas como sendo o motivo principal da adoção de contratos pelas usinas.

Mesmo não sabendo exatamente qual será o preço do etanol durante a safra, a usina precisa estabelecer uma programação de vendas que faça frente às suas despesas ao longo do tempo. Como as despesas estão vinculadas à produção industrial e, conseqüentemente, ao andamento da colheita da cana, parte das vendas precisará acompanhar este processo para que haja equilíbrio no fluxo de caixa da empresa. Para garantir este alinhamento, as usinas lançam mão de contratos.

De acordo com a terminologia adotada no modelo teórico de Bogetoft e Olesen (2004), podese dizer que o contrato não influencia o andamento da produção industrial, mas coordena a estocagem, ou seja, determina a quantidade de produto que a usina pretende manter em estoque, durante certo período.

\footnotetext{
${ }^{73}$ No sentido de processado, fabricado.
} 
Desta forma, à medida que a usina fecha um contrato com uma distribuidora, assumindo o compromisso de disponibilizar uma determinada quantidade de etanol, numa determinada data, para sua cliente, ela resolve seu problema de garantia de fluxo de caixa, pois, mediante o contrato, tem a venda do produto garantida.

Vale comentar que ao fazer isto, seu produto passa a carregar uma especificidade temporal, além da especificidade locacional que já carregava devido à localização particular de qualquer usina.

Em consequência desta colocação dos agentes sobre a necessidade das usinas de garantia de fluxo de caixa, surgiu o seguinte questionamento: uma usina não poderia simplesmente seguir uma programação própria, utilizando o mercado spot para escoar seus produtos, e evitar ceder os tais descontos sobre o indicador Esalq quando opta pelo uso de contratos?

A resposta para isto foi que seria muito arriscado contar com o mercado spot para escoar $100 \%$ das vendas. Mesmo que as vendas fossem programadas ao longo do ano, a liquidez desse mercado não seria grande o suficiente para garantir que em todos os momentos escolhidos pela usina realmente haveria comprador para seu produto. Além disso, aumentaria seu gasto com capital humano na área de vendas.

De qualquer forma, deve-se lembrar que a avaliação do risco de se apoiar mais ou menos no mercado spot com a intenção de planejar sua venda frente a determinado fluxo de caixa, é particular de cada agente. Essa avaliação também parece depender do volume que o agente pretende escoar, pois seria mais fácil equacionar a venda de volumes menores, e da praça em que a usina está ofertando, pois quanto mais demandada for a praça, menor será o risco de falta de liquidez.

\subsubsection{Disposição ao risco}

Contratos permitem certa previsão de fluxo de caixa, porém não deixam com que a empresa especule a melhor posição de vendas no tempo. Se o agente tiver disposição ao risco, ele preferirá não fechar contratos, carregar seus estoques, poupar-se do desconto, e tentar vender seu produto apenas no momento de alta de preço. Essa tomada de posição exige uma segunda condição além de disposição ao risco, exige fôlego financeiro para não comprometer seu fluxo de caixa enquanto carrega seu estoque. Além disso, uma usina deve ter a estrutura de 
armazenagem adequada para se propor a carregar estoques, nesse caso a tancagem deve ser maior que a das que não se propõem a isso.

Conforme explicado no capítulo 4, a produção do etanol acompanha a safra de cana, o que cria um certo perfil de produção e, conseqüentemente de oferta. De acordo com esse perfil, espera-se que em dezembro, fim da safra, e nos meses da entressafra: janeiro, fevereiro e março, os preços estejam elevados. À medida que a produção se inicia, os preços começam a cair. Geralmente, o patamar mais baixo é alcançado entre maio, junho e julho, começando novamente a subir, a partir daí, até o fim da safra (Bacchi, 2006). Usinas com disposição ao risco irão buscar o melhor momento para vender seu etanol dentro dessa dinâmica.

O Gráfico 2 apresentado a seguir, mostra o perfil de variação do preço do etanol durante a safra, e o nível médio do indicador Esalq neste período, tomando como exemplo os preços de anidro durante o ano de 2005. Agentes tomadores de risco procuram vender apenas no momento em eles supõem que o preço está melhor que o valor médio do indicador, pois, um resultado igual à venda neste valor médio, seria o resultado obtido vendendo de forma linear, sem especulação, como no caso da opção por contratos. Para tanto, no momento em que o preço é mal avaliado por estes agentes, eles saem do mercado e carregam seus estoques até o momento que o preço volte a ser atrativo

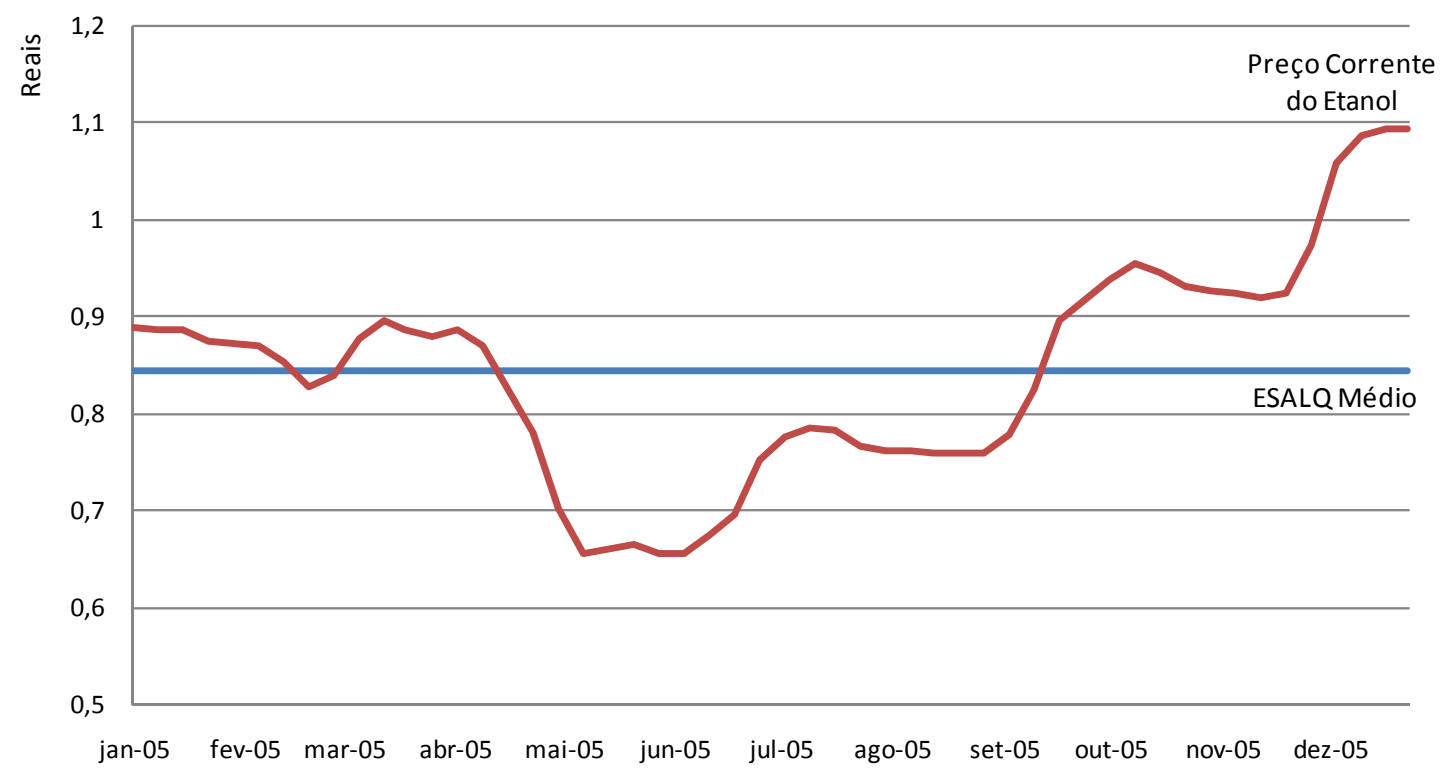

Gráfico 2: Perfil da variação do preço durante a safra e o momento ideal da venda FONTE: Elaborado pelo Autor com base nas entrevistas 


\subsubsection{A organização dos agentes em grupos de comercialização}

As usinas procuram formar grupos de comercialização, pois percebem que desta forma podem usufruir de economias de escala, além de aumentar seu poder de barganha frente às distribuidoras, durante a comercialização do etanol.

Vendendo conjuntamente, as usinas podem utilizar o mesmo capital humano para gerenciar esta atividade, além de manter um único escritório para operacionalizar o processo.

O poder de barganha das usinas aumenta à medida que sua atratividade para as distribuidoras aumenta. Unidas em grupos, as usinas podem se comprometer a fornecer um grande volume de etanol, o que interessa às distribuidoras. Tal fato coloca o grupo de comercialização numa posição melhor frente às distribuidoras do que as usinas conseguiriam separadamente.

Além do interesse comum em escala e poder de barganha, a formação dos grupos também é modulada pela afinidade comercial dos agentes, principalmente o grau de aversão ao risco, e por questões relacionais.

Conforme colocado no capítulo 2, Ménard (2004) classifica este tipo de organização como uma forma híbrida, e Brousseau (2006) apresenta estas organizações como instituições privadas, em seu modelo de mudança institucional.

Vale lembrar que os grupos de comercialização detêm aproximadamente 50\% de toda a venda de etanol das usinas para as distribuidoras, sendo de grande importância o entendimento de sua função.

\subsubsection{A opção de governança das usinas}

Além dos determinantes apresentados na última seção: a garantia de fluxo de caixa e a disposição ao risco, as características peculiares de cada agente também têm que ser levadas em consideração ao analisar sua tomada de posição.

Cada usina dispõe de um nível de produção, uma determinada posição geográfica e um grau de envolvimento em grupos de comercialização. Estes três fatores, somados, determinam em grande parte o poder de barganha de uma usina. Observando as colocações feitas até agora 
sobre as estratégias e a política de vendas das usinas, pode-se dizer que, de acordo com a necessidade de garantia de fluxo de caixa e de sua disposição ao risco, cada usina usará seu poder de barganha para estabelecer juntamente com sua contraparte a estrutura de governança que melhor lhes convir.

A seguir serão apresentadas as opções de estrutura de governança das usinas, iniciando pelas posições tomadas pelos grupos de comercialização. Informações específicas de cada grupo de comercialização relacionadas ao tema serão acrescentadas durante o texto para permitir a compreensão adequada do assunto. Vale comentar que estas informações foram colhidas diretamente a partir das entrevistas com os executivos de cada grupo.

A Copersucar adota o uso de contratos e mercado spot. Esta cooperativa representa os interesses de 28 usinas, sendo que os contratos são estabelecidos entre a própria Copersucar e as distribuidoras de combustíveis. As usinas cooperadas têm a obrigação de fornecer toda sua produção de etanol e açúcar, referente aos 3 anos subseqüentes à sua subscrição, à Copersucar. A própria Copersucar negocia e assume a responsabilidade dos contratos frente às distribuidoras. No caso da Copersucar, é a entidade grupo de comercialização quem tem a voz ativa, ou seja, quem dá a palavra final na decisão entre contratar ou vender no mercado spot. Para atuar no mercado spot, a Copersucar tem uma estrutura interna própria, ou seja, uma mesa de operações para viabilizar suas vendas.

A Sociedade Corretora de Álcool, SCA, também está envolvida em vendas spot e via contratos, mas de uma forma diferente da Copersucar. A SCA não é uma cooperativa e sua função é oferecer a seus associados o serviço de operacionalizar suas vendas. A SCA tem uma estrutura interna própria, uma mesa de operações para atuar no mercado spot, e, à medida que é solicitada por seus associados, ela articula tal venda. Quanto aos contratos, a SCA dá suporte na negociação dos mesmos, mas o contrato é assumido pelas usinas e não pela entidade grupo de comercialização. A SCA detém conhecimento e informação mercadológica, mas a decisão final entre contratar ou vender no mercado spot é tomada por cada associado individualmente. Dessa forma, pode-se encontrar associados que preferem não vender via 
contratos, utilizando apenas o mercado spot, como é o caso da Usina Monte Alegre ${ }^{74}$, ou associados que usam contratos e mercado spot, como é o caso do Grupo Moema.

Vale comentar que um número significativo de associados da SCA compõe o Grupo Crystalsev. A Crystalsev é uma empresa, um grupo de comercialização, que foi criada por uma série de usinas, entre elas a Santeliza Vale e o Grupo Moema, para comercializar seus produtos. O açúcar de seus associados é comercializado diretamente pela Crystalsev, e o etanol é comercializado através da SCA no mercado spot e via contratos. No caso da Crystalsev, diferente da Copersucar, são as próprias usinas que mantêm contrato com as distribuidoras de combustíveis.

A Cosan, maior produtora nacional de etanol, também usa os serviços da SCA, conforme aponta o site desta corretora.

A Bioagência não atua na comercialização via contratos, só no mercado spot. Seus associados não utilizam contratos. Da mesma forma que os outros grupos citados anteriormente, a Bioagência conta com uma estrutura interna de mesa de operação e oferece o serviço de articular a venda spot a seus associados. No caso da Bioagência, a empresa, assim como a Copersucar e SCA, também detém informação e conhecimentos mercadológicos, sendo que a tomada de decisão final de venda, nesse caso, a decisão do momento de venda, é do associado. Tais associados estão ligados ao grupo de comercialização não apenas para operacionalizar suas vendas, mas para utilizar todo conhecimento mercadológico oferecido pelo grupo para nutrir seu processo decisório quanto ao momento certo de vender. No caso da Bioagência, os associados não detêm a propriedade do grupo de comercialização.

A CPA Trading também comercializa seu etanol apenas via mercado spot. Este grupo de comercialização é uma empresa independente cuja propriedade está nas mãos das usinas associadas a ela. A CPA tem exclusividade sobre a comercialização de toda produção de seus associados e também comercializa a produção de algumas usinas chamadas de representadas, que não detêm participação sobre o grupo de comercialização.

\footnotetext{
${ }^{74}$ Tanto a Usina Monte Alegre como o Grupo Moema autorizaram a divulgação destas informações.
} 
As diferentes opções de governança observadas podem ser visualizadas no Quadro 7 onde estão relacionadas aos diferentes perfis dos agentes.

Quadro 7: As opções de governança das usinas

\begin{tabular}{|c|c|c|c|c|c|c|c|c|}
\hline \multicolumn{5}{|c|}{ Perfil } & \multicolumn{4}{|c|}{ Governança } \\
\hline \multirow{2}{*}{ Risco } & \multirow{2}{*}{ Organização } & \multirow{2}{*}{ Agente } & \multirow{2}{*}{$\begin{array}{c}\mathbf{N}^{\mathbf{0}} \text { de } \\
\text { Usinas }\end{array}$} & \multirow{2}{*}{ Share } & \multirow{2}{*}{ SPOT } & \multicolumn{2}{|c|}{ Contratos } & \multirow{2}{*}{ Integr. } \\
\hline & & & & & & Relac. & Formais & \\
\hline \multirow{4}{*}{$\begin{array}{c}\text { Mais } \\
\text { tomadoras } \\
\text { de risco }\end{array}$} & \multirow{3}{*}{$\begin{array}{l}\text { Organizadas em } \\
\text { grupos de } \\
\text { comercialização }\end{array}$} & Bioagência & 16 & $6,83 \%$ & $\mathrm{x}$ & & & \\
\hline & & Cosan & 15 & $7,89 \%$ & $\mathrm{x}$ & $\mathrm{x}$ & $\mathrm{x}$ & $\mathrm{x}$ \\
\hline & & CPA Trading & 14 & $4,24 \%$ & $\mathrm{x}$ & & & \\
\hline & $\begin{array}{c}\text { Não Organizadas } \\
\text { em grupos de } \\
\text { comercialização }\end{array}$ & Outras & \multirow{2}{*}{145} & \multirow{2}{*}{$48,52 \%$} & $\mathrm{x}$ & & & \\
\hline \multirow{4}{*}{$\begin{array}{l}\text { Menos } \\
\text { tomadoras } \\
\text { de risco }\end{array}$} & $\begin{array}{l}\text { Não Organizadas } \\
\text { em grupos de } \\
\text { comercialização }\end{array}$ & Outras & & & $\mathrm{x}$ & $\mathrm{x}$ & $\mathrm{x}$ & \\
\hline & \multirow{3}{*}{$\begin{array}{l}\text { Organizadas em } \\
\text { grupos de } \\
\text { comercialização }\end{array}$} & Copersucar & 28 & $16,91 \%$ & $\mathrm{x}$ & & $\mathrm{x}$ & \\
\hline & & SCA & 22 & $8,46 \%$ & $\mathrm{x}$ & & $\mathrm{x}$ & \\
\hline & & Crystalsev & 9 & $7,15 \%$ & $\mathrm{x}$ & & $\mathrm{x}$ & \\
\hline
\end{tabular}

FONTE: Elaborado pelo autor com base nas entrevistas

A mesma conclusão apresentada para a escolha da governança das distribuidoras reflete a escolha das usinas, ou seja, a governança mista entre o mercado spot e os contratos é a opção de governança que acomoda da melhor forma os anseios estratégicos das usinas e ainda minimiza os custos de transação inerentes à comercialização do etanol. A postura da Copersucar, SCA e da Crystalsev seria um exemplo disto.

Novamente, alguns agentes aparecem com opções diferentes do mix entre contratos e mercado spot. Estes agentes têm características intrínsecas muito específicas, o que os leva a adotar uma estratégia singular.

De acordo com o racional proposto até agora, a integração vertical promovida pela Cosan não seria justificável apenas por questões de otimização logística e garantias de escoamento. Essa “jogada” deve ser entendida como parte de uma tomada de posição mais ampla e específica da 
Cosan, que deve ter seus motivos para acreditar que, apesar de passar a incorrer em custos maiores, assim mesmo terá mais lucro operando de forma integrada. Sendo assim, não se espera que outros grupos usineiros saiam ao mercado tentando comprar distribuidoras, pois a integração vertical não é a estrutura de governança que maximiza o lucro integrado dessa transação, minimizando os custos de transação.

Da mesma forma, a tomada de posição da Usina Monte Alegre, trabalhando totalmente alavancada no mercado spot, deve ser entendida como uma posição particular desta empresa, em que seus proprietários esperam obter um lucro capaz de suplantar as economias que teriam trabalhando com a governança mista, ao escolher o momento certo para vender seu estoque. Vale comentar que a Monte Alegre faz parte do Grupo Adecoagro, o que lhe dá fôlego financeiro enquanto se propõe a isso.

Algumas usinas optam por contratos relacionais. Em alguns casos, por ser um meio termo no que se refere a assumir um compromisso, podendo, desta forma, ser uma opção mais adequada ao seu perfil, capacidade de produção e necessidade de garantir seu fluxo de caixa. Em outros casos, simplesmente não é possível formatar o contrato, como por exemplo, em regiões afastadas do Estado de São Paulo onde o indicador Esalq já não retrata a realidade dos preços.

\subsection{Ambiente institucional e as diferenças de governança entre hidratado e anidro.}

As três últimas seções deste capítulo discutiram a dinâmica da relação entre usinas e distribuidoras, porém, sem apontar o motivo de tamanha diferença de opção de governança em se comparando anidro e hidratado. Como dito no início do capítulo, quase $80 \%$ do anidro é comercializado via contratos, contra apenas 40\% do hidratado.

As discussões até agora foram feitas sob observações momentâneas, sem levar em consideração a evolução dos fatos no tempo e sem discutir as particularidades de cada mercado em separado. A proposta da atual seção é recuar um pouco no tempo e analisar a evolução da governança desses produtos até a data atual, vinculando tal discussão às características de cada mercado e promovendo uma leitura de resultados sob a mesma ótica teórica, para complementar o entendimento das seções anteriores. 
Para tanto, serão apresentadas a seguir, três seções. A primeira delas será dedicada a uma breve revisão de questões relevantes à formação do ambiente institucional que envolve a transação em estudo, e a segunda irá discutir como este ambiente institucional influencia a escolha da estrutura de governança pelos agentes. A terceira e última seção apresenta o caso da Usina Moema, ilustrando o conteúdo discutido até então, a partir da apresentação da evolução da estrutura de governança adotada por ela, nos últimos anos.

\subsubsection{O ambiente institucional}

Como já comentado no capítulo 2, de acordo com North (1990), o ambiente institucional pode ser compreendido como as regras de um jogo, enquanto os agentes econômicos seriam os jogadores. No caso da distribuição de combustíveis no Brasil, o componente mais relevante do ambiente institucional são os impostos que incidem sobre a comercialização.

Para North (1990), os contornos do mercado, as oportunidades e desafios, são dados pelo arcabouço institucional, nesse caso, principalmente pela trama de impostos que incidem sobre essa atividade.

Quando se discute o ambiente institucional, deve-se levar em consideração não apenas as limitações impostas aos agentes pelas regras, mas a capacidade de enforcement desse regramento pelas autoridades competentes.

A política fiscal do setor, a fraca capacidade das autoridades de coibir infratores, e o perfil pessoal de alguns empresários, fez do mercado de distribuição um ambiente atrativo a agentes que se utilizavam de fraude fiscal como diferencial competitivo, após a desregulamentação do setor.

A seguir, serão apresentadas quatro situações em que o regramento imposto pelo governo para coordenar esta atividade influencia diretamente o delineamento das oportunidades e riscos na comercialização do etanol e, conseqüentemente, também influencia a ocorrência ou não de práticas de sonegação fiscal e adulteração de combustíveis. 


\subsubsection{A fraude do anidro molhado}

Uma das formas de fraude praticada por distribuidoras desleais era comprar o anidro, cujo ICMS é zero, adicionar água e vender como hidratado. Como o ICMS do hidratado era, na média dos estados, 25\%, a distribuidora que se dispusesse a fazer tal operação, poderia não recolher tal imposto, sonegando, e ter uma margem de lucro extraordinária.

Dentro desse mesmo processo, a distribuidora desleal poderia também acrescentar mais água ao anidro, ultrapassando os níveis aceitos de água no hidratado, para aumentar ainda mais sua lucratividade na transação.

Recentemente, a ANP editou a Resolução 36/2005, de 19 de dezembro de 2005, que obriga a adição de corante laranja ao anidro, para desestimular essa fraude. Neste caso, o regramento atua diminuindo a assimetria de informação da cadeia, pois cria uma diferença visual aparente entre o anidro e hidratado.

A ANP também passou a proibir a venda de anidro às distribuidoras que não tivessem as respectivas cotas de gasolina A que justificassem sua necessidade pelo produto, aumentando o controle da agência sobre a atividade. Tais medidas tiveram o efeito esperado: a diminuição de ações fraudulentas e ilegais.

\subsubsection{Evasão fiscal por triangulação de ICMS}

A diferença de alíquota de ICMS entre os estados brasileiros foi largamente explorada para sonegação. Distribuidoras desleais compravam hidratado com destino a algum estado cujo ICMS fosse baixo, como é o caso de Goiás, cuja alíquota era 15\%, e, ilegalmente, entregavam no Estado de São Paulo, onde a alíquota era bem mais alta, 25\% no caso. Nesse processo, a distribuidora desleal conseguia uma margem extraordinária entre as diferenças de alíquotas.

O Governo do Estado de São Paulo foi extremamente solicitado pelas grandes distribuidoras a resolver esta questão, num claro exemplo de mudança institucional aos moldes do discurso de North. A partir do estímulo dos agentes econômicos, e de seu próprio interesse, o governo tomou a seguinte medida no final de 2003: baixou a alíquota do ICMS do estado para 12\%, a menor alíquota da federação, editando a Lei Estadual $n^{0}$ 11.593. O resultado dessa medida corrigiu esta distorção e possibilitou, mesmo com a diminuição da alíquota, que o governo 
aumentasse a arrecadação de impostos sobre a atividade devido ao desestímulo à sonegação e a fuga de várias distribuidoras desleais do mercado.

\subsubsection{A transferência da responsabilidade de arrecadação do PIS/COFINS das distribuidoras para as usinas}

Em 2008, o governo federal editou a Medida Provisória 413/2008 que transfere a responsabilidade de arrecadar o PIS/COFINS da comercialização do etanol para as usinas. Até então, esta responsabilidade era das distribuidoras.

Distribuidoras desleais podem simplesmente sonegar este imposto e aumentar sua competitividade. Na visão das grandes distribuidoras, essa medida só veio a melhorar sua posição, pois seria mais um desestímulo à sonegação por parte da distribuição.

Para o lado da produção, a medida não foi bem recebida, pois da mesma forma que a sonegação pode ocorrer na distribuição, também poderia ocorrer do lado da produção. De acordo com os dois entrevistados que representaram a organização setorial, essa medida estava gerando um desconforto enorme em muitos usineiros por medo de que este novo arranjo viesse a estimular usinas desleais a tirar proveito desta oportunidade para ganhar competitividade sonegando o imposto.

Analisando esta mudança no ambiente institucional pela ótica de North, conclui-se que o estímulo inicial proveniente dos agentes econômicos para os agentes políticos, deve ter vindo apenas das grandes distribuidoras, pois esta mudança só privilegiou a sua posição.

\subsubsection{A nova lei do embandeiramento}

A Resolução ANP n ${ }^{0}$ 7, de 07 de março de 2007, conhecida vulgarmente como a nova regra do embandeiramento, reforça a obrigação dos postos de abastecimento bandeirados de comprar o combustível apenas de suas distribuidoras de origem. Resumidamente, a fidelidade do posto franqueado passa a ser maior à sua distribuidora, desestimulando a compra de combustível proveniente de distribuidoras concorrentes, leais ou desleais. 
De acordo com o entrevistado representante da distribuidora emergente contatado, este novo arranjo piora a situação de todas as pequenas distribuidoras, as que agem honestamente e as que operam na ilegalidade, pois diminui a demanda do mercado por seus produtos.

\subsubsection{O reflexo das distorções do mercado sobre a governança do setor}

Conforme os exemplos citados na última seção, percebe-se que as distribuidoras desleais, enquanto conseguem operar sonegando, criam um enorme diferencial competitivo.

Logo após a desregulamentação do setor, o mercado de hidratado passou a ter contornos mais atraentes à sonegação que o mercado de anidro. A estrutura fiscal neste momento oferecia mais oportunidades a agentes com perfil desleal na distribuição do hidratado do que na distribuição do anidro.

Num mercado em que as margens são bastante apertadas, deixar de pagar um imposto cuja alíquota é 25\%, como no caso do anidro molhado, leva o agente sonegador a um patamar de competitividade praticamente inalcançável pelo não sonegador.

De acordo com o relato dos entrevistados, na época em que a sonegação estava em seu auge, entre 2002 e 2003, as distribuidoras do Sindicom, responsáveis por 70\% dos postos de abastecimento nesse momento, detinham $80 \%$ do volume de gasolina comercializado, frente a apenas $30 \%$ de hidratado ${ }^{75}$. Isso indicava que os postos estavam sendo abastecidos por distribuidoras concorrentes que conseguiam oferecer o hidratado a um preço muito mais atraente aos postos franqueados das grandes distribuidoras, além de atender os postos bandeira branca.

A esse fenômeno, de ter seus postos sendo abastecidos por distribuidoras concorrentes, foi dado o nome, no jargão do mercado, de “despejo”. Um entrevistado representando uma distribuidora do Sindicom comenta que, em determinada fase, a sua distribuidora chegou a operar com margem negativa na venda de hidratado para enfrentar a concorrência e manter seus postos abastecidos impendido que estas se relacionassem com outras distribuidoras. Isso

\footnotetext{
${ }^{75}$ Vale comentar que, de acordo com o Sindicom, suas associadas detinham $50 \%$ do mercado de hidratado e 75\% do mercado de gasolina C. Mesmo assim, a discrepância entre as participações nestes dois mercados continua sendo significativa (SINDICOM, 2008)
} 
no sentido de desestimular futuros negócios entre seus postos e qualquer outra distribuidora, evitando a perda de pontos de venda.

Neste momento, enquanto as distribuidoras do Sindicom perdiam mês após mês sua fatia do mercado de hidratado para as distribuidoras desleais, surge um reflexo direto na estrutura de governança do setor. As distribuidoras desleais não estavam interessadas em fazer contratos, isso não fazia o menor sentido dentro de sua estratégia, usando apenas o mercado spot para adquirir hidratado ou anidro (para ser "molhado”). Como apenas as distribuidoras do Sindicom tinham motivação à contratação, isto levou a uma prática de baixa utilização de contratos como forma de governança.

Estas distorções da dinâmica do mercado impostas pela prática de sonegação, fortalecendo distribuidoras desleais, também causavam um segundo efeito sobre a governança. As distribuidoras do Sindicom, neste momento, passaram a considerar inadequado o indicador Esalq do hidratado como parâmetro de seus contratos, ficando desmotivadas a usar essa forma de governança.

As distribuidoras desleais aceitavam geralmente pagar um preço um pouco mais elevado pelo produto, pois dentro de sua estratégia, a lucratividade vinha da sonegação, e não de uma política de compras agressiva. Dessa forma, o valor do indicador Esalq do hidratado, que corresponde ao valor médio do preço no mercado spot, ficava inflacionado quando usado pelas distribuidoras como indicador de preço dos contratos. Conforme apontado por um dos executivos das distribuidoras do Sindicom, enquanto o desconto médio do contrato de anidro girava em torno de $2 \%$, o desconto médio do contrato de hidratado deveria ser de $8 \%$ para evitar esse efeito.

\subsubsection{Mudança Institucional e a retomada do Sindicom}

Várias mudanças no regramento que controla o mercado de distribuição foram implementadas na tentativa de conter a sonegação.

Como dito anteriormente, durante a discussão do anidro molhado”, o governo federal impôs o uso de corante laranja na formulação do anidro, para evitar que este fosse "molhado" e enviado ilegalmente ao mercado de hidratado. 
A diminuição do ICMS no estado de São Paulo, já comentada anteriormente durante a discussão da triangulação deste imposto, foi a medida de maior impacto sobre a sonegação, e marcou o início da recuperação da participação das distribuidoras do Sindicom no mercado de hidratado.

O conjunto dessas mudanças no ambiente institucional vem provocando a retomada do mercado de hidratado pelas distribuidoras do Sindicom, e a diminuição da sonegação fiscal. Conseqüentemente, as distorções causadas pela sonegação também vêm diminuído, e observou-se um aumento na taxa de adoção de contratos sobre o uso do mercado spot como forma de governança no mercado de hidratado, a partir daí. De acordo com o Sindicom, em 2008, a média do Share de suas associadas já alcança 68\% do mercado de hidratado e $87 \%$ do mercado de gasolina $\mathrm{C}$.

No momento atual, 2008, ainda existe uma grande diferença na governança do anidro e hidratado, mas essa diferença, que já foi maior, tende a diminuir ainda mais com o "fortalecimento" do ambiente institucional contra a sonegação. Um executivo entrevistado chegou a dizer que, em sua opinião, com as medidas fiscais adequadas, o mercado deve evoluir para o emparelhamento da fatia de mercado de hidratado à do anidro nas distribuidoras do Sindicom.

Analisando o desenvolvimento das relações entre os agentes econômicos após a desregulamentação, conforme discutido neste capítulo até agora, ficou clara a forte influência do ambiente institucional sobre a formação do arcabouço de oportunidades e riscos a que estão expostos estes agentes, e a influência de suas escolhas sobre a dinâmica das relações que assim ficam estabelecidas, como é o caso da estrutura de governança.

A seguir, será apresentado um conjunto de dados da Usina Moema que ilustra toda a discussão elaborada até agora no capítulo. 


\subsubsection{O caso da Usina Moema}

Nesta seção serão apresentados e discutidos os valores percentuais do etanol comercializado via contratos e via mercado spot, pela usina Moema, nas últimas 10 safras.

Antes de abordar a questão da diferença de governança da Moema nos mercados de hidratado e anidro, será feito um breve resumo do histórico desta empresa.

\subsubsection{A Usina Moema}

A Usina Moema, fundada em 1978, está localizada no noroeste do Estado de São Paulo, no município de Orindiúva.

Inicialmente, a Moema foi concebida como uma destilaria, começando sua produção de hidratado e anidro em 1982. Só no final da década de 80 a Moema passou a fabricar açúcar. De acordo com a tabela 4.1, apresentada no capítulo 4, a Moema foi a $9^{\mathrm{a}}$ maior produtora de etanol do centro-sul na safra $2006 / 07^{76}$.

A Moema faz parte de um grupo industrial usineiro comandado por duas famílias tradicionais do Agronegócio Cana, a família Junqueira e a família Biagi. A Figura 15 apresentada a seguir, mostra as unidades fabris do grupo. Conforme comentado na seção 7.4.2, a Moema comercializa toda sua produção de açúcar e etanol através do grupo de comercialização Crystalsev.

\section{Grupo Moema}

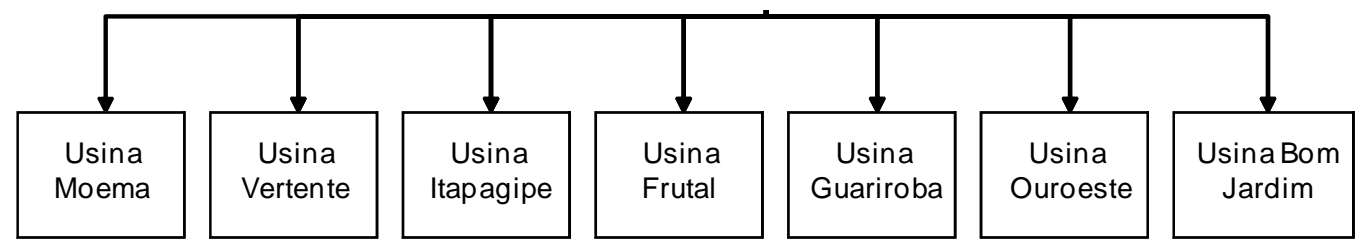

Figura 15: O Grupo Moema

FONTE: Elaborado pelo autor com informações cedidas pela Usina Moema

\footnotetext{
${ }^{76}$ Na safra 2006/07 apenas as unidades: Moema, Itapagipe e Vertente estavam ativas.
} 


\subsubsection{Diferenças na governança do hidratado e anidro no caso da Moema}

O caso da Usina Moema chama atenção por se enquadrar às descrições feitas pelos executivos entrevistados em geral, sobre a governança na comercialização de etanol e suas diferenças entre o mercado de hidratado e anidro.

No início do capítulo, foi dito que no ano de 2008, vários executivos entrevistados, além dos executivos da Moema, acreditavam que os contratos correspondem a $80 \%$ de todo o volume de anidro comercializado no centro-sul e $40 \%$ de todo hidratado. Esta previsão é exatamente o retrato das operações da Moema neste momento, como se pode observar nos Gráficos 3 e 4, apresentados a seguir.

Um segundo ponto de concordância entre os dados da Moema e o conteúdo já colocado neste capítulo está na observação de que a contratação do anidro evoluiu de forma mais rápida que a do hidratado, além de ter alcançado um patamar mais alto. Isto corrobora com o cenário apresentado na seção 7.5.2, no qual se observou que o resultado da influência do ambiente institucional propiciou maior sonegação no mercado de hidratado, fazendo com que sua contratação evoluísse lentamente quando comparada à do anidro. 
O Gráfico 3 traz a comparação percentual das vendas de hidratado via contratos e via mercado spot feitas pela Moema nas últimas 10 safras. Apesar da safra 2008/09 ainda não haver acabado até então, a previsão dos contratos e da produção completa da safra foi considerada como um dado.

No caso do hidratado, a Moema deve fechar a safra de 2008/09 comercializando 40\% do volume via contratos e $60 \%$ pelo mercado spot. Uma curva de tendência pôde ser traçada para a comercialização via contratos usando os dez pontos levantados ${ }^{77}$. A curva de tendência gerada, representada pela equação $\mathrm{y}=0,047 \mathrm{x}$, apresenta um $\mathrm{R}^{2}$ de 0,65 , o que confirma a existência de tendência ao aumento da contratação pela Usina Moema nas últimas safras.

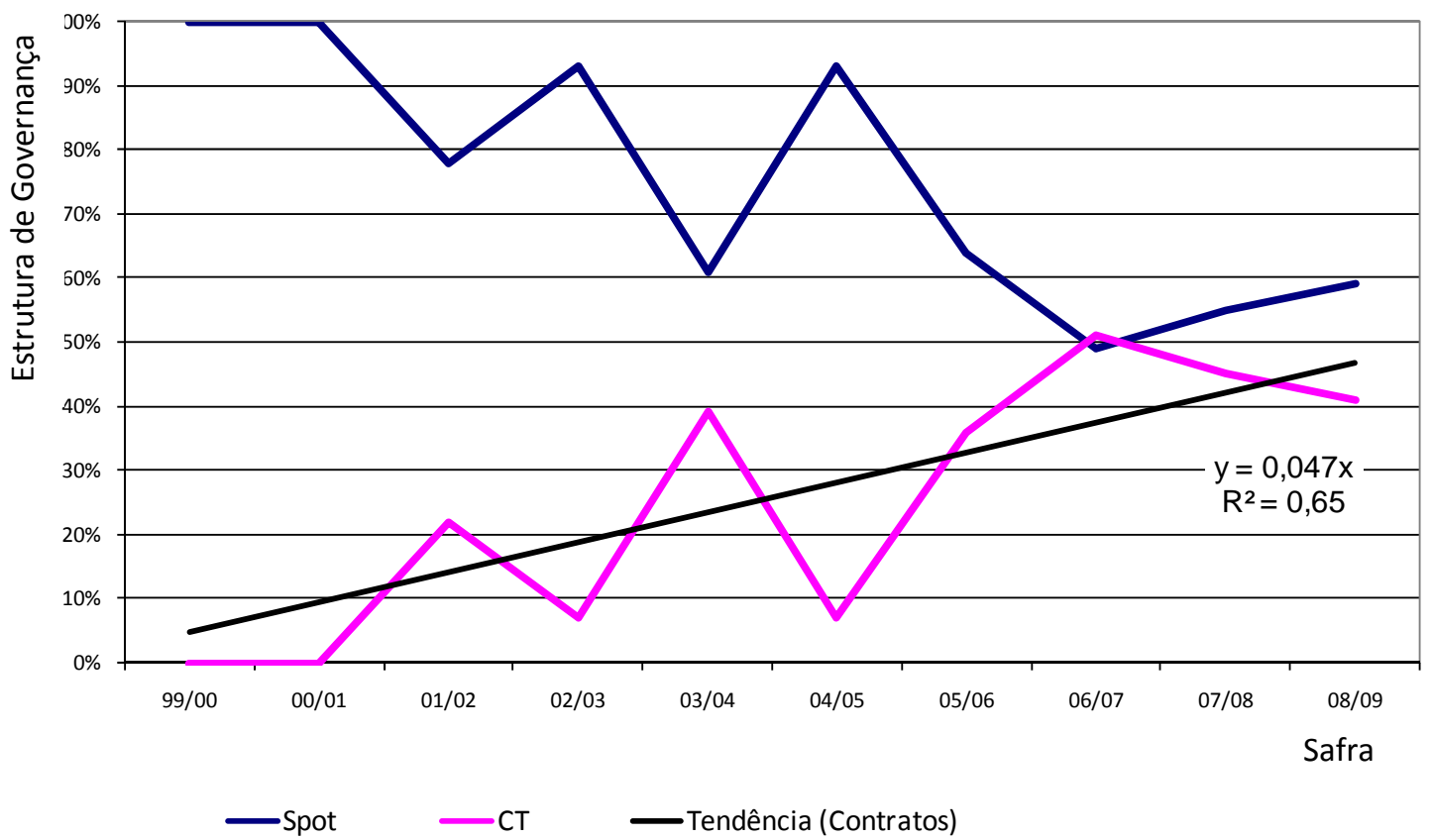

Gráfico 3: Evolução da governança do etanol hidratado da Usina Moema FONTE: Elaborado pelo autor com base nos dados fornecidos pela Usina Moema

\footnotetext{
${ }^{77}$ A reta de tendência foi traçada utilizando o método de regressão linear dos mínimos múltiplos quadrados ordinários.
} 
Conforme o Gráfico 4, no caso do anidro, a Usina Moema deve fechar a safra de 2008/09 comercializando $80 \%$ do volume via contratos e $20 \%$ pelo mercado spot. Uma curva de tendência também pôde ser traçada usando as informações cedidas pela mesma ${ }^{78}$. A curva de tendência gerada, representada pela equação $y=0,077 x$, com $R^{2}$ de 0,85 , confirma a existência de tendência de aumento da contratação de etanol anidro nas últimas safras.

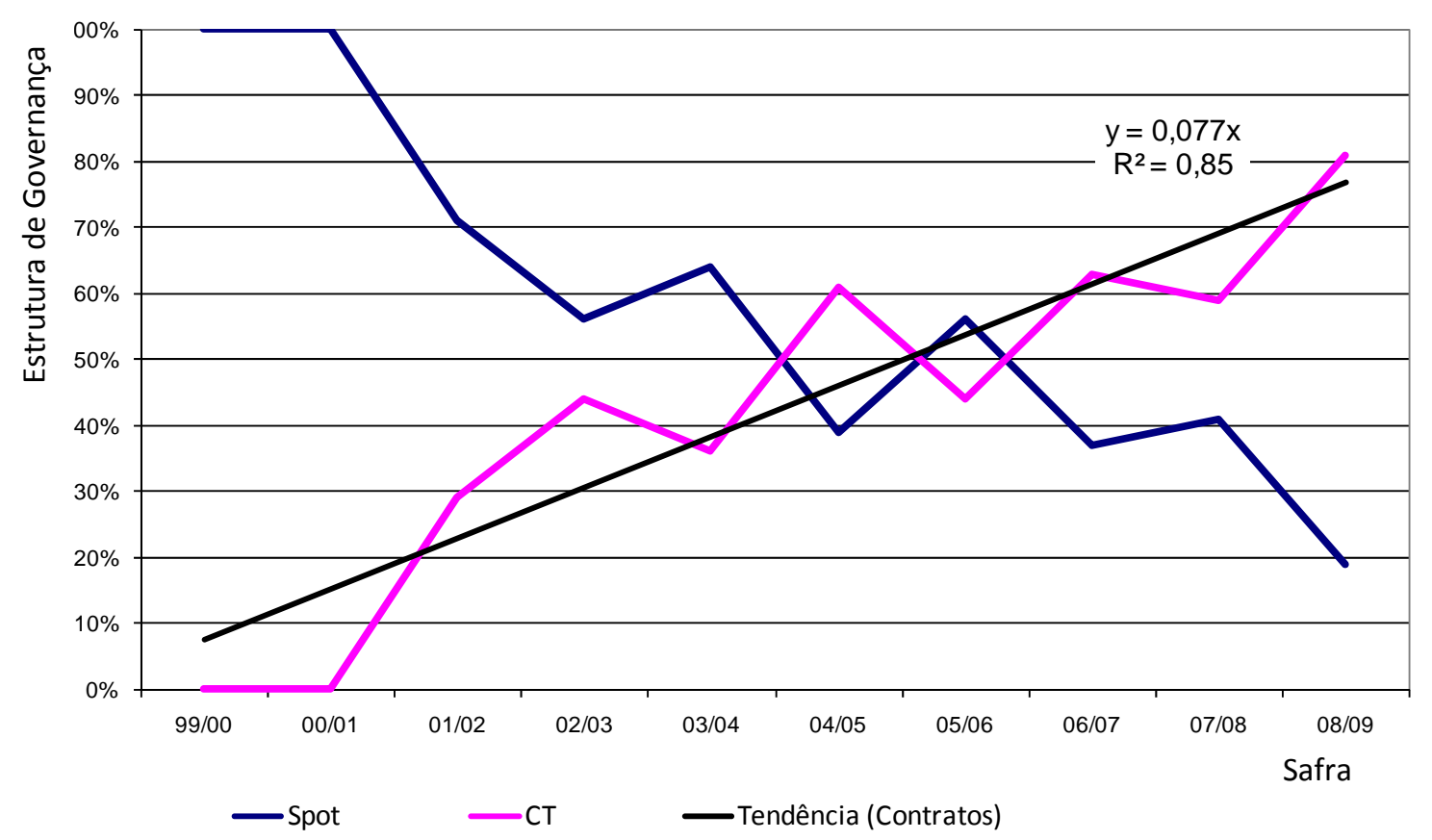

Gráfico 4: Evolução da governança do etanol anidro da Usina Moema

FONTE: Elaborado pelo autor com base nos dados fornecidos pela Usina Moema

Comparando-se o coeficiente angular das duas curvas discutidas, 0,077 para o anidro e 0,047 para o hidratado, percebe-se que a inclinação da curva que representa a contratação do anidro é 64\% maior que a representante da contratação do hidratado, evidenciando a maior rapidez da evolução da contratação do anidro conforme comentado no início desta seção.

\footnotetext{
${ }^{78}$ A reta de tendência foi traçada utilizando o método de regressão linear dos mínimos múltiplos quadrados ordinários.
} 


\subsection{Conteúdo estruturado sob o modelo teórico de Bogetoft e Olesen (2004)}

Uma particularidade da proposta de Bogetoft e Olesen (2004) está na forma de abordar os custos de transação. Vale a pena repassar esse ponto, antes de entrar na análise propriamente dita.

Os quatro últimos tópicos propostos pelos autores tratam de custos de transação, na maioria, custos ex-post. Apesar desta estrutura analítica dar grande destaque aos Custos de Entrada, de Resolução de Conflitos, de Monitoramento e de Influência, a compreensão da racionalidade da relação entre usinas e distribuidoras, agregando coordenação, motivação e custos de transação, mostrou que os custos de transação derivados da presença de especificidade locacional e temporal na transação, cuja ocorrência é ex-ante ao contrato, são os fatores de maior relevância nesta análise. Sendo assim, para esse caso específico, o último terço do modelo de análise, referente exclusivamente a custos de transação ex-post ao contrato, teve uma importância secundária ao entendimento dos fatos estudados. ${ }^{79}$

A seguir, será apresentada a discussão de cada um dos quatorze pontos do modelo proposto por Bogetoft e Olesen (2004), apontando sua influência no lucro integrado da relação entre usinas e distribuidoras.

\section{Coordenação do processo produtivo}

O processo produtivo é a soma da produção industrial e da estocagem. A produção industrial $^{80}$ não é coordenada pelo contrato, mas pela produção agrícola. $O$ contrato estabelece volumes e datas para retirada, o que coordena a estocagem nas usinas, ou seja, a disponibilidade locacional e temporal do produto, e coordena a programação logística de retirada das distribuidoras. Desta forma, pode-se dizer que o contrato coordena o processo produtivo, apesar de não coordenar a produção industrial.

Neste caso, o efeito sobre o lucro integrado é positivo.

\footnotetext{
${ }^{79}$ Vale, entretanto, uma observação à estrutura proposta pelos autores, já que o modelo aborda os custos totais de coordenação e motivação como se os custos de transação nestas categorias fossem pouco relevantes à análise.

${ }^{80}$ O termo PRODUÇÃO INDUSTRIAL está sendo empregado conforme a classificação adotada no modelo teórico de Bogetoft e Olesen (2004), onde PRODUÇÃO e ESTOCAGEM, juntos, formam o chamado PROCESSO PRODUTIVO
} 


\section{Coordenação do comportamento de mercado.}

Deve-se destacar aqui o caso do contrato ser usado como instrumento estratégico de compras pelas distribuidoras, conforme discutido na seção 7.3.1.2. Nesse caso específico, a cláusula que dá liberdade de antecipar ou atrasar retiradas pela distribuidora estaria dando a elas condições de exercer poder de mercado. Neste caso, o efeito sobre o lucro integrado é negativo.

Porém, a adoção de contratos determina a adoção de um compromisso linear de vendas, provocando um efeito de diminuição da especulação de preços no mercado. Isso porque, a diminuição do volume disponível que pode ser manipulado pelas empresas no mercado spot, devido à canalização da produção às vendas via contrato, restringe a possibilidade de eventuais movimentos especulativos de entrada e saída do mercado, ou até de coordenação ${ }^{81}$ de preços entre os agentes, ou seja, diminui a existência de peso morto, tornando o mercado mais eficiente. Neste caso, apesar de indireto, o efeito sobre o lucro integrado é positivo. $\mathrm{O}$ mesmo raciocínio vale para a linearização das compras.

Não é possível afirmar categoricamente qual seria o efeito final da soma destes dois efeitos antagônicos. Resolveu-se considerar o efeito conjunto positivo, devido à adoção dos contratos ser intensiva a ponto de $80 \%$ do anidro estar sendo negociado desta forma.

\section{Coordenação da distribuição do risco}

O risco de enfrentar turbulências no escoamento do etanol ${ }^{82}$ vinculado às usinas, e o risco de assumir compromissos demasiadamente antecipados para as distribuidoras, ficam equacionados pela adoção deste tipo de contrato, pois o desenho deste contrato, conforme o conteúdo do capítulo 7, permite que os agentes assumam apenas o nível de risco que realmente estão dispostos a assumir.

Neste caso, o efeito sobre o lucro integrado é positivo.

\footnotetext{
${ }^{81}$ O texto não se propõe a discutir a existência ou não de cartelização, apenas apontar o efeito do contrato caso isso ocorra.

${ }^{82}$ Como explicado na seção 7.4, não é possível garantir a realização de uma venda no mercado spot, no exato momento em que uma usina resolve vender
} 


\section{Coordenação da minimização do risco}

Este contrato diminui o risco total da cadeia, pois sua função básica é criar condições para que usinas e distribuidoras possam, efetivamente, se relacionar comercialmente, conforme explicado no item anterior. Este fato diminui o risco operacional da cadeia como um todo, diminuindo o risco de desabastecimento. Por outro lado, o contrato não altera em nada o risco de mercado da cadeia, ou seja, o contrato não diminui o risco de, eventualmente, os consumidores perderem o interesse pelo etanol.

Neste caso, o efeito sobre o lucro integrado é positivo.

\section{Motivação à participação}

O desenho contratual oferece motivação às usinas programando seu fluxo de caixa e poupando gastos com equipe de vendas. Para as distribuidoras, o contrato oferece as condições de planejamento logístico necessárias para tanto.

Neste caso, o efeito sobre o lucro integrado é positivo.

\section{Motivação e esforço a tarefas múltiplas}

Os agentes adeptos à contratação tendem a manter um self-enforcement aos contratos devido a questões relacionais, visando a continuidade futura da relação comercial, além de estarem sujeitos a multas por descumprimento do contrato. Vale lembrar que, para Bogetoft e Olesen (2004), o descumprimento de um contrato está sempre vinculado ao redirecionamento dos interesses do agente a alguma outra tarefa.

As usinas têm certa flexibilidade ${ }^{83}$ para mudarem seu mix açúcar e álcool, mesmo durante a safra. Essa decisão é influenciada por seu nível de compromisso frente a seus contratos préestabelecidos.

As distribuidoras têm o mesmo cuidado com seus compromissos contratuais, não abandonando a comercialização já contratada de hidratado por gasolina.

\footnotetext{
${ }^{83}$ Conforme colocado na seção 7.4, durante a safra, o mix pode variar em até $10 \%$
} 
No caso do anidro, o compromisso ao contrato é reforçado por influência do regime de cotas de aquisição de gasolina A ao qual as distribuidoras estão submetidas. Se uma distribuidora diminuir seu volume de compras de gasolina A, sua cota será automaticamente diminuída, o que é difícil reverter no futuro. Desta forma, temendo perder as cotas, as distribuidoras fazem um grande esforço para escoar toda a gasolina A que compraram, em forma de gasolina $\mathrm{C}$, a qual precisa de anidro para ser fabricada.

Neste caso, o efeito sobre o lucro integrado é positivo.

\section{Motivação e esforço a produtores múltiplos}

O contrato não traz em sua matriz de incentivos ou punições, qualquer cláusula que vincule esforço individual ao esforço de um grupo.

Neste caso, o efeito sobre o lucro integrado é neutro.

\section{Motivação ao investimento evitando problemas de hold-up}

Bogetoft e Olesen (2004) atribuem esse tópico à proteção de um eventual hold-up sobre investimentos a serem feitos no futuro, ou seja, investimentos ex-post. No caso, o contrato não aborda investimentos ex-post.

Neste caso, o efeito sobre o lucro integrado é neutro.

Na prática, esse contrato está protegendo investimentos ex-ante ao contrato, ao assegurar a transação comercial. Usinas e distribuidoras chegam ao momento de negociação já tendo feito seus investimentos. As usinas já estão operando e industrializando a cana, enquanto as distribuidoras já têm suas bases, frotas e postos funcionando. Para Bogetoft e Olesen (2004), esta questão de investimento ex-ante está incluída na discussão de distribuição e minimização de riscos, tratadas nos itens 3 e 4, e a questão de punição por descumprimento do contrato está incluída no item 6, sobre motivação e esforço a tarefas múltiplas.

Vale comentar que contratos de exportação têm perfil completamente diferente, sendo o caso da negociação entre Petrobras e Mitsui um exemplo de contrato que prevê inúmeros investimentos futuros. No caso, em estruturas de logística. 


\section{Motivação ao investimento adequando os horizontes}

Nesse caso, assim como todos os tópicos ligados a investimentos, Bogetoft e Olesen (2004) também estão se limitando à discussão de horizonte de investimento futuro. Como o contrato não trata de investimento futuro, não existe cláusula pertinente a essa questão.

Neste caso, o efeito sobre o lucro integrado é neutro.

Vale comentar que o horizonte médio deste contrato é de 1 ano-safra ou 1 ano civil. Esse horizonte, tido como de curto prazo pelo mercado, está ligado aos investimentos ex-ante dos agentes e está de acordo com o nível de risco que cada agente está disposto a tomar. As distribuidoras não querem se comprometer por mais tempo por serem muito avessas ao risco de se tornarem pouco competitivas frente às suas concorrentes, e as usinas não querem um compromisso mais longo para poder avaliar seu mix açúcar/etanol e anidro/hidratado a cada safra.

\section{Motivação ao investimento num portfólio equilibrado}

O contrato não trata de questões de portfólio, pois não discute investimentos futuros.

Neste caso, o efeito sobre o lucro integrado é neutro.

A cada fim de ano, conforme apontado no item 9, as usinas e distribuidoras fazem um plano estratégico para a safra seguinte. A posição que elas irão tomar durante a safra é decidida $e x-$ ante ao contrato, conseqüentemente, o portfólio de investimentos e riscos dos agentes é tomado antes da contratação. O contrato acaba sendo um instrumento para viabilizar as estratégias assumidas no início do período citado, ou seja, pela proposta de Bogetoft e Olesen (2004), essa questão também recai no âmbito do item 3. 


\section{Custos de entrada}

Para Bogetoft e Olesen (2004), os itens relevantes nessa questão são os itens ligados ao contingenciamento de eventualidades, e aos custos de redigir adequadamente o contrato, formatando a linguagem a contento das partes e a contento do poder judiciário.

O contingenciamento é feito de forma específica sobre as questões de logística, indicando a margem de tolerância e a responsabilidade dos agentes quanto aos volumes e datas de retirada, assim como em relação ao cálculo do preço a partir do indicador Esalq. Este contrato também se propõe a contingenciar situações resultantes de grandes mudanças institucionais, porém de forma generalista, apenas apontando que, em virtude de mudanças significativas no mercado, principalmente na política fiscal do setor, as partes se comprometem a rever o acordo firmado, abrindo inclusive a possibilidade de suspenderem o mesmo.

O custo de redigir o contrato é minimizado à medida que o contrato traz uma cláusula de renovação por mais um período, diluindo no tempo de vigência do contrato, despesas com renegociações e recontratações.

Neste caso, o efeito sobre o lucro integrado é positivo.

\section{Resolução de conflitos}

Dois mecanismos são usados para indicar a resolução de conflitos. Em alguns casos, a solução é dada pela indicação de um dos agentes como árbitro, na maioria das vezes esse papel fica com a distribuidora. Em outros casos, o contrato apenas indica que as partes devem se comprometer em resolver um eventual conflito, conjuntamente, e de boa fé. Por fim, é indicado o Foro a ser usado caso o poder judiciário seja acionado.

Vale lembrar que a maioria dos conflitos está vinculado a uma estreita faixa de possibilidades de desacordo, ligada às posições de volumes e datas acordados. De acordo com as entrevistas, a incidência de casos de conflito e quebra contratual que chegaram ao poder judiciário é muito baixa.

Neste caso, o efeito sobre o lucro integrado é positivo. 


\section{Monitoramento.}

O contrato estabelece as bases para o monitoramento, ou seja, estabelece quais deverão ser as práticas comerciais e de qualidade a serem adotadas pelos agentes. O documento também dá o direito às partes de monitorar suas contrapartes no tocante às práticas acordadas. Um dos pontos mais relevantes é o estabelecimento de uma especificação técnica para o produto, no caso, a especificação da ANP.

Neste caso, o efeito sobre o lucro integrado é positivo.

\section{Custo de influência}

O custo de influência é minimizado pela objetividade do contrato, não deixando "janelas” para dificuldades de comunicação durante a vigência do mesmo. Nesse caso, a natureza da transação facilita a limitação deste custo, pois o etanol tem atributos bem definidos.

Neste caso, o efeito sobre o lucro integrado é positivo.

A seguir, no Quadro 8, será apresentado o conteúdo destes quatorze pontos, indicando a influência de cada um deles sobre o lucro integrado da relação entre usinas e distribuidoras, e se o contrato discutido aborda ou não cada assunto. 


\subsubsection{Apresentação gráfica do conteúdo}

Quadro 8: Conteúdo geral resumido

\begin{tabular}{|c|c|c|c|c|}
\hline & & & $\begin{array}{c}\text { O Contrato } \\
\text { Aborda } 0 \\
\text { Tema }\end{array}$ & $\begin{array}{c}\text { Efeito sobre } \\
\text { o lucro } \\
\text { integrado }\end{array}$ \\
\hline \multirow{4}{*}{ Coordenação } & \multirow{2}{*}{$\begin{array}{l}\text { Coordenação da } \\
\text { Produção }\end{array}$} & $\begin{array}{l}\text { Processo de } \\
\text { produção }\end{array}$ & Sim & + \\
\hline & & $\begin{array}{l}\text { Comportamento de } \\
\text { Mercado }\end{array}$ & Sim & + \\
\hline & \multirow{2}{*}{$\begin{array}{l}\text { Coordenação do } \\
\text { Risco }\end{array}$} & $\begin{array}{l}\text { Distribuição do } \\
\text { Risco }\end{array}$ & Sim & + \\
\hline & & $\begin{array}{l}\text { Minimização do } \\
\text { Risco }\end{array}$ & Sim & + \\
\hline
\end{tabular}

\begin{tabular}{|c|c|c|c|c|}
\hline \multirow{6}{*}{ Motivação } & & Participação & Sim & + \\
\hline & \multirow{2}{*}{ Esforço } & Tarefas Múltiplas & Não & + \\
\hline & & $\begin{array}{l}\text { Produtores } \\
\text { Múltiplos }\end{array}$ & Não & Neutro \\
\hline & \multirow{3}{*}{ Investimento } & $\begin{array}{l}\text { Problema de Hold } \\
\text { - up }\end{array}$ & Não & Neutro \\
\hline & & $\begin{array}{l}\text { Problema de } \\
\text { Horizonte }\end{array}$ & Não & Neutro \\
\hline & & $\begin{array}{l}\text { Problema de } \\
\text { Portfólio }\end{array}$ & Não & Neutro \\
\hline
\end{tabular}

\begin{tabular}{|l|l|c|c|}
\hline \multirow{2}{*}{ Custos de Transação } & Custo de Entrada & Sim & + \\
\cline { 2 - 4 } & $\begin{array}{l}\text { Resolução de } \\
\text { Conflitos }\end{array}$ & Sim & + \\
\cline { 2 - 4 } & Monitoramento & Sim & + \\
\hline & $\begin{array}{l}\text { Custo de } \\
\text { Influência }\end{array}$ & Sim & + \\
\hline
\end{tabular}

FONTE: Elaborado pelo autor com base nas entrevistas 


\section{ANÁLISE}

A última etapa do método científico pelo modelo de Richardson (1999) leva o nome de Análise. Esta etapa finaliza o trabalho avaliando o teste de hipótese proposto e discutindo o modelo inicial que deu origem à hipótese a partir dos resultados obtidos na pesquisa.

Para complementar o capítulo serão indicadas algumas sugestões de novas pesquisas que poderão ser feitas na mesma linha deste trabalho.

\subsection{Avaliação do teste de hipótese}

Na formulação dos objetivos específicos deste trabalho, foi proposto o seguinte teste de hipótese:

H0: De acordo com a NEI, custos de transação não justificam a escolha de governança na relação entre usinas e distribuidoras de combustíveis.

H1: De acordo com a NEI, custos de transação justificam a escolha de governança na relação entre usinas e distribuidoras de combustíveis.

De acordo com todo conteúdo exposto no capítulo anterior, percebe-se que a afirmação tomada como hipótese alternativa (H1) é verdadeira e deve ser aceita.

\subsection{A racionalidade da relação entre usinas e distribuidoras}

Usinas e distribuidoras de combustíveis têm necessidade de estruturar seu relacionamento para maximizar os ganhos de ambas as partes no processo de comercialização do etanol. A ocorrência de contratos como mecanismo de governança nesta transação é a evidência de que esta necessidade está sendo suprida pela adoção de um acordo bilateral formal entre estes agentes.

A necessidade de adotar contratos como mecanismo de coordenação é causada pela existência de custos de transação no relacionamento comercial entre usinas e distribuidoras, derivados da especificidade de ativos locacional e temporal inerentes à comercialização do etanol. Os agentes do setor, conforme explica a Nova Economia Institucional, optam pela melhor forma 
de minimizar estes custos utilizando os contratos como principal estrutura de governança em seu relacionamento.

Sendo assim, tanto usinas como distribuidoras não devem maximizar seus resultados caso adotem o mercado spot ou a integração vertical como principal estrutura de governança. Quando isso ocorre, deve-se atentar às características específicas do agente em questão, pois o agente que assume esta posição acredita que irá conseguir um resultado final melhor, apesar de estar deixando de minimizar seus custos de transação, do que aquele que teria, caso insistisse na utilização de contratos. Um exemplo esclarecedor é o da Usina Monte Alegre que opera apenas no mercado spot para poder ter condições de especular o melhor momento para realizar suas vendas, o que gera um ganho maior do que a perda incorrida ao utilizar uma estrutura de governança sub ótima.

A Nova Economia Institucional também sustenta que o arcabouço institucional que permeia o relacionamento dos agentes econômicos, determina em grande parte as oportunidades e riscos que se apresentam a eles. No caso da comercialização do etanol, as instituições formais são as que mais influenciam o comportamento dos agentes, pois a trama de impostos que se aplicam à transação desta commodity tem um efeito determinante sobre a viabilidade de qualquer estratégia que um agente pretenda utilizar neste setor.

A Figura 16 apresentada a seguir, ilustra a racionalidade da escolha do mecanismo de governança para estruturar a comercialização de etanol entre usinas e distribuidoras de combustíveis, evidenciando o processo de tomada de decisão de cada um deles, em separado 

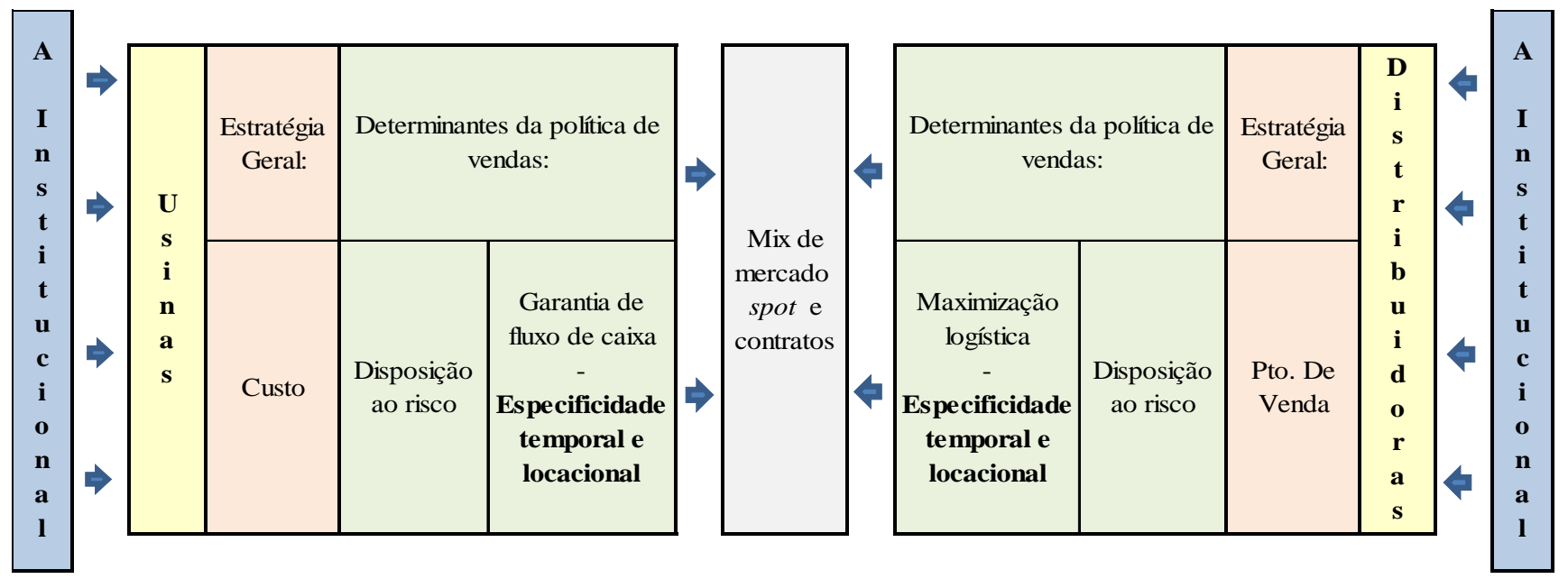

Figura 16: A racionalidade da relação entre usinas e distribuidoras FONTE: Elaborado pelo Autor com base nas entrevistas

No caso das usinas, a particularidade da posição geográfica de cada planta industrial responde pela especificidade de ativo locacional. A especificidade temporal decorre da falta de liquidez do mercado, não havendo garantia de que haverá um comprador disponível no exato momento que a usina quiser vender.

A existência destes custos de transação confere certa limitação à venda do etanol, impedindo que qualquer agente, realize uma venda do volume que quiser, no exato momento que desejar.

As usinas, como quaisquer empresas, precisam de equilíbrio de fluxo de caixa. Neste caso, as despesas dos agentes estão atreladas ao andamento da produção do etanol, pois a maior preocupação estratégica das usinas é minimizar seus custos de produção, o que só acontece se a produção ocorrer à medida que a cana for sendo colhida, ou seja, de acordo com a safra. Sendo assim, a melhor opção para uma usina é alinhar seus recebimentos às suas despesas, estabelecendo uma programação para as vendas.

Desta forma, surge a seguinte questão: como garantir que a programação de vendas será cumprida, apesar das limitações impostas pelos custos de transação? A resposta é a utilização de contratos.

Conforme ilustra a Figura 16, os agentes não utilizam apenas contratos em todas as suas transações. Na prática, eles utilizam um mix de contratos e mercado spot. No caso das usinas, quanto menor o risco de desequilíbrio no fluxo de caixa, ou de não conseguir realizar uma 
venda em um momento desejado, maior será sua utilização de contratos frente ao uso do mercado spot.

Conforme os comentários iniciais desta seção, a opção por contratos exercida pelas distribuidoras também é causada pela existência de custos de transação. Neste caso, as especificidades locacionais e temporais dos ativos criam uma limitação à operação logística destes agentes, pois não é possível maximizar o resultado deste tipo de operação sem um conhecimento mínimo dos locais e datas onde os produtos deverão ser retirados.

Sendo assim, as distribuidoras irão buscar contratos para garantir o conhecimento prévio dos locais e datas que certo volume de etanol deverá estar à sua disposição.

A maior preocupação estratégica das distribuidoras é a sua rede de revendedores, seus pontos de venda. Dentro desta estratégia, as distribuidoras percebem que é essencial manter-se competitivas em relação às suas concorrentes para não perder seus pontos de venda.

Para manter a competitividade, as distribuidoras devem comprar o etanol da melhor forma possível, criando as condições necessárias à otimização logística, sem se exporem a qualquer risco que poça fazer com que ocorra uma perda em sua capacidade competitiva, como por exemplo, o risco de fechar antecipadamente uma compra em certo preço e, no momento da realização, o preço ofertado no mercado estar abaixo do contratado.

O contrato padrão adotado na comercialização do etanol consegue viabilizar estas duas necessidades, pois garante o compromisso de locais, datas e volumes, sem que aja fixação de preço ex-ante, maior fator de risco neste mercado.

Desta forma, quanto maior a necessidade de previsão para maximizar a operação logística, maior será a utilização de contratos frente ao uso do mercado spot.

Por fim, deve-se atentar ao fato que o poder de barganha de cada agente irá sempre influenciar as negociações. Neste caso, o desconto aplicado ao indicador Esalq, parâmetro de preço adotado no contrato padrão, é a forma encontrada para sinalizar as peculiaridades de cada transação, incluindo o poder de barganha dos agentes, assim como seus níveis particulares de disposição ao rico. 


\subsection{Indicação de estudos futuros}

Dois caminhos podem ser seguidos a partir deste trabalho: aumentar o conhecimento sobre o mesmo assunto estudado ou aumentar o conhecimento ao longo desta cadeia de suprimento.

Uma possibilidade seria aplicar a mesma metodologia, método de análise e coleta, alterando apenas o modelo teórico adotado, sobre o mesmo tema, para obter uma visão do problema estudado sobre outra perspectiva.

Outra possibilidade seria utilizar a metodologia de Estudo de Caso, ao invés da Grounded Theory, para estudar a relação em questão. Em princípio, pode-se apontar quatro casos distintos cujo estudo seria interessante: o caso de uma usina que não participa de grupos de comercialização, o caso de um grupo de comercialização, o caso de uma pequena distribuidora e o caso de uma distribuidora do Sindicom.

No sentido de aumentar o conhecimento ao longo dessa cadeia de suprimentos, poderiam ser feitos os mesmo trabalhos nos próximos elos, na relação entre distribuidoras e postos de abastecimento e na relação entre os postos e o consumidor final. 


\section{REFERÊNCIAS}

AGÊNCIA NACIONAL DO PETRÓLEO, GÁS NATURAL E BIOCOMBUSTÍVEIS (ANP). Lista de Agentes Econômicos, 2006. Disponível em: $<$ http://www.anp.gov.br/doc/anuario2006/Lista_de_Agentes_Economicos.pdf $>$. Acessado em: 08/10/2007. (a)

AGÊNCIA NACIONAL DO PETRÓLEO, GÁS NATURAL E BIOCOMBUSTÍVEIS (ANP). Tabela 2.38 - Capacidade de armazenamento de petróleo, seus derivados e álcool etílico, segundo terminais, em 31/12/2005, 2005 . Disponível em: $<$ http://www.anp.gov.br/doc/anuario2006/T2.38.xls >. Acessado em: 08/10/2007. (b)

AGÊNCIA NACIONAL DO PETRÓLEO, GÁS NATURAL E BIOCOMBUSTÍVEIS (ANP). Tabela 3.1 - Quantidade de bases de distribuição de combustíveis líquidos derivados de petróleo e de álcool automotivo, segundo Grandes Regiões e Unidades da Federação, em 31/12/2005, $2005 \quad$. Disponível em: $<$ http://www.anp.gov.br/doc/anuario2006/T3.1.xls>. Acessado em: 08/10/2007. (c)

AGÊNCIA NACIONAL DO PETRÓLEO, GÁS NATURAL E BIOCOMBUSTÍVEIS (ANP). Cartograma 2.1 - Infra-estrutura para movimentação de Petróleo, seus derivados e álcool etílico - 2005, 2005. Disponível em: $<$ http://www.anp.gov.br/doc/anuario2006/Cartograma\%202.1.pdf>. Acessado em: 08/10/2007. (d)

AKERLOFF, G. A. The Market for Lemons: quality uncertainty and the market mechanism. Quarterly Journal of Economics, n. 84, p. 488-500, 1970.

ALCHIAN, A. A.; DEMSETZ, H. Production, information costs and economic organization. American Economic Review, Princeton, v. 62, p. 777 - 795, 1972.

ARROW, K. J. The Economics of information. Harvard University Press, 1984

ARROW, K. J. The limits of the organization. New York: Norton, 1974.

BACCHI, M.R.P. Estoques reguladores de álcool. O Estado de São Paulo, São Paulo, caderno B, p. 2., 20/04/2006

BANDEIRA-DE-MELLO, R. em GODOI, C. K.; BANDEIRA-DE-MELLO, R.; SILVA, A. B. Pesquisa qualitativa em estudos organizacionais paradigmas, estratégias e métodos, São Paulo: Saraiva, 2007.

BARZEL, Y. Economic Analysis of Property Rights. Cambridge: Cambridge University Press, 1989.

BOGETOFT, P; OLESEN, H. Design of production contracts: lessons from theory and agriculture. Copenhagen: Copenhagen Business School Press, 2004. 
BOUÇAS, C. Shell e Codexix fazem parceria global na área de bioenergia. Valor Econômico, 07/11/2007. Disponível em: $<$ http://infoener.iee.usp.br/infoener/hemeroteca/imagens/108028.htm> acesso em: 07/11/2007.

BRAGATO, I. R.; MARJOTTA-MAISTRO. M. C. Corante no Anidro Combustível: Aumento da Credibilidade do Produto. Artigos Cepea Álcool, 01/05/2006. Disponível em: $<$ http://www.cepea.esalq.usp.br/pdf/Cepea_corante_alcool.pdf $>$ Acessado em: 20/11/2007.

BROUSSEAU, E.; RAYNAUD, E. The economics of private institutions: an introduction to the dynamics of institutional frameworks and to the analysis of multilevel multi-type governance. Paris: Université Paris I, 2006. (Working paper).

CARVALHO, E. P. D. Outlook on Ethanol. Hart World Refining \& Fuels Conference: Americas, Rio de Janeiro, Agosto, 2006.

CARVALHO, E. P. D. Perspectivas da Agroenergia. Seminário BM\&F: Perspectivas para o Agribusiness 2007 e 2008, 2007. Disponível em: http://www.fiesp.com.br/agronegocio/pdf/outlook\%20bmf\%20\%20perspectivas\%20da\%20agroenergia\%20\%20eduardo\%20pereira\%20de\%20carvalho\%20(04.2007).pdf Acessado em: 14/12/2007

CHAUI, M. Convite à Filosofia. São Paulo: Editora Ática, 13ª edição, p. 84, 2004.

CHEUNG, S. On The New Institutional Economics. Em: Cheung et alli. Contract Economics, p. 48-75, 1990.

COASE, R. H. The nature of the firm. Economica, v. 4, p. 386-405, 1937.

COASE, R. H. The problem of social cost. Journal of Law and Economics, 3, n. 1, p. 1-44, 1960.

COLLIS, J.; HUSSEY, R. Pesquisa em Administração, Porto Alegre: Bookman, 2005.

COMMONS, J. R. Institutional Economics: its place in political economy. New York: Macmillan, 1934.

COMPANHIA NACIONAL DE ABASTECIMENTO (CONAB). Terceiro Levantamento Novembro de 2006, 2006. Disponível em: <http://www.conab.gov.br/conabweb/download/safra/3_levantamento0708_nov2006.pdf>. Acessado em: 28/03/2007.

CONSELHO DOS PRODUTORES DE CANA-DE-AÇÚCAR, AÇÚCAR E ÁLCOOL DO ESTADO DE SÃO PAULO (CONSECANA). Maual de Instrução, $5^{\text {a }}$ Ed, 2006. Disponível em: < http://www.unica.com.br/search.asp>. Acessado em: 7/11/2008 
COOTER, R.; ULEN, T. Law and Economics. Glenview, Sott, Foresman and Company, 1988.

CORREA, C. Efeito Etanol. Revista Exame, Editora Abril: São Paulo, edição 899, p.22-27, 2007.

COSTA, C. C. D. Formação de Preços de Açucar e Álcool Combustível Anidro e Hidratado no Estado de São Paulo. Dissertação de Mestrado, 2000.

COSTA. E. A. D. Resinas elevam receita de usina de álcool. Jornal Gazeta Mercantil, 24/07/2007. Disponível em: $<$ http://infoener.iee.usp.br/infoener/hemeroteca/imagens/105158.htm>. Acessado em: 24/07/2007.

DEMSETZ, H. Toward a theory of property rights. The American Economic Review, Princeton, v. 57, n. 2, p. 347 - 359, 1967.

EGGERTSSON, T. Economic behavior and institutions. Cambridge: Cambridge University Press, 1990.

FARINA, E. M. M. Q.; AZEVEDO, P. S.; SAES, M. S. M. Competitividade: Mercado, Estado e Organizações. São Paulo: Editora Singular, 1997.

FERREIRA, A. B. D. H. Novo Dicionário. São Paulo: Nova Fronteira, p. 1201, 1974.

FIGUEIREDO, R. Gargalos Logísticos na distribuição de combustíveis brasileira. Artigos CEL, $2006 . \quad$ Disponível em: $<$ http://www.centrodelogistica.com.br/new/art_Gargalos_Logisticos_na_dist_de_combust.pdf $>$. Acessado em: 08/10/2007

FLANAGAN, J. C. The critical incident technique, Psicological Bulletin, 51, July, pp. 327358, 1954.

FURUBOTN, E.; RICHTER, R. The New Institutional Economics: An Assessment. Em: Furubotn and Richter eds., The New Institutional Economics. College Station, Texas: Texas A\&M Press, 1991.

GLASER, B. Basics of Grounded Theory Analysis. Emergence vs Forcing. Mill Valley: Sociology Press, 1992.

GLASER, B. Doing Grounded Theory - Issues and Discussions. Mill Valley: Sociology Press, 1998

GLASER, B. Theoretical sensitivity. Mill Valley: Sociology Press, 1978. 
GLASER, B.; STRAUSS, A. The discovery of grounded theory: strategies for qualitative research. New York: Aldine de Gruyter, 1967.

GOULDING, C. Grounde theory: a practical guide for management, business and market researchers. London: Sage, 2002.

HAIR . J. F.; BABIN, B.; MONEY, A. H.; SAMOUEL, P. Fundamentos de métodos de pesquisa em administração. Porto Aledre: Bookman, 2005.

HARDIN, G. The tragedy of the commons. Science, 162, p. 1243-1248, 1968.

HAYECK, F. A. The use of knowledge in society. The American Economic Review, v. 35, n. 4, p. $519-530$, Sep. 1945.

INACIO, A. Mistura de álcool anidro na gasolina vai a $\mathbf{2 5 \%}$. Jornal O Estado de São Paulo, 14/06/2007. Disponível em: $<$ http://infoener.iee.usp.br/scripts/infoener/hemeroteca/EmDiaComEnergia.asp?decriterio=14 \%2F6\%2F07\&buPesquisar=Pesquisar>, acessado em: 14/06/2007

JANK, M. S. Perspectivas do Etanol no Brasil e no Mundo. Painel: Bioenergia: Etanol e Biodiesel, São Paulo, 9 de novembro de 2006. Disponível em: <http://www.iconebrasil.org.br/arquivos/noticia/20.pdf>, Acessado em: 20/11/2007

JENSEN. M.; MECKLING, W. Theory of the Firm: Managerial Behaviour, Agency Costs and Ownership Structure. Journal of Financial Economics, v.3, p. 305-360, 1976.

KLEIN, B. The role of incomplete contracts in self-enforcing relationships. Revue D'Economie Industrielle, n. 92, p. 67-80, 2000.

KLEIN, B.; CRAWFORD, R. G.; ALCHIAN, A. A. Vertical integration, appropriable rents, and the competitive contractive process. The Journal of Law and Economics, Chicago Press, v. 21, 1978.

KNIGHT, F. H. Risco, incerteza e lucro. Rio de Janeiro: Expressão e Cultura, 1972.

LOBATO, E. Usineiros do NE ameaçam ir ao Cade contra a Petrobras. Folha de São Paulo, 13/11/2007. Disponível em: http://infoener.iee.usp.br/infoener/hemeroteca/imagens/108334.htm, acessado em: 13/11/2007.

MARCELLO, J. D. Entrevista com o Gerente de Planejamento e Mercado da Sociedade Corretora de Álcool (SCA). 2007

MÉNARD, C. The Economics of Hybrid Organizations. Journal of Institutional and Theoretical Economics, Mohr Siebeck, v. 160, n. 3, p. 345 - 376, 2004. 
MILGROM, P.; ROBERTS, J. Economics, Organization and Management. New Jersey: Prentice Hall, 1992.

MINISTÉRIO DA AGRICULTURA, PECUÁRIA E ABASTECIMENTO (MAPA). Relação das Usinas Produtoras Cadastradas no Departamento de Cana-de-Açúcar e Agroenergia. POSIÇÃO 17/08/2007, 2007. Disponível em: $<$ http://www.agricultura.gov.br/pls/portal/docs/PAGE/MAPA/SERVICOS/USINAS_DESTIL ARIAS/USINAS_CADASTRADAS/UPS_17_08_2007_0.PDF>. Acessado em: 17/08/2007. (A)

MORAES, M. A. F. D. A desregulamentação do setor sucroalcooleiro do Brasil. Piracicaba, Tese (Doutorado em Ciências) - Escola Superior de Agricultura Luiz de Queiroz, Universidade de São Paulo, 1999.

MORAES, M. A. F. D.; SHIKIDA, P. F. A. Agroindústria Canavieira no Brasil. São Paulo: Atlas, 2002.

MORI, J. S. Características do Mercado do Álcool Anidro e Hidratado e suas Implicações para o Mercado de Combustíveis. Congresso da Sociedade Brasileira de Economia, Administração e Sociologia Rural - SOBER, Londrina, PR, 2007.

NEVES, Marco F. et al. O sistema agroindustrial da cana-de-açúcar: caracterização das transações entre empresas de insumos, produtores de cana e usinas. In: Anais do Congresso da Sociedade Brasileira de Economia e Sociologia Rural - SOBER, v.1, pp. 559572, 1998.

NORTH, D. C. Custos de Transação, Instituições e Desempenho Econômico. Rio de Janeiro: Instituto Liberal, 1994(a).

NORTH, D. C. Economic Performance Through Time. The Americam Economic Review, American Economic Association, v.84, n. 3, p. 359-368, 1994(b).

NORTH, D. C. Institutions, Institutional Change and Economic Performance. New York: Cambridge University Press, 1990.

PEASE, C. M.; BULL, J. M. Scientific Decision-making. Disponível em: http://www.utexas.edu/courses/bio301d/Table.of.contents.html. Acessado em: 10/05/2008.

PEDROSO JÚNIOR, R Arranjos institucionais na agricultura brasileira. Dissertação apresentada ao Departamento de Administração da Faculdade de Economia, Administração e Contabilidade da Universidade de São Paulo como requisito para obtenção do título de Mestre em Administração. São Paulo, 2008.

PETROBRAS TRANSPORTES S.A. (TRANSPETRO). A empresa: Transpetro. Disponível em: $<$ http://www.transpetro.com.br/portugues/empresa/transpetro/transpetro.shtml>. Acessado em: 08/10/2007 (a) 
PETROBRAS TRANSPORTES S.A. (TRANSPETRO). Condições Gerais de Serviço: Álcool.

<http://www.transpetro.com.br/portugues/negocios/dutosTerminais/files/CGSA3.pdf>

Acessado em: 08/10/2007 (b)

PETROBRAS TRANSPORTES S.A. (TRANSPETRO). Tarifas de Referência para Serviços de Movimentação de Álcool. Disponível em: $<$ http://www.transpetro.com.br/portugues/negocios/dutosTerminais/files/TarifasAlcool01.pdf >. Acessado em: 08/10/2007 (c)

PETROBRAS TRANSPORTES S.A.(TRANSPETRO). Tarifa de Transferência para Serviços de Transporte Dutoviário - Dutos Curtos. Disponível em: $<$ http://www.transpetro.com.br/portugues/negocios/dutosTerminais/files/TarifasDutosCurtos. pdf $>$. Acessado em: 08/10/2007. (d)

RICHARDSON, R. J. Pesquisa social: métodos e técnicas. São Paulo: Atlas, $3^{\text {a }}$ Ed. 1999.

RODRIGUES, T. R. Comunicação pessoal com o Gerente Comercial da Bioagência. 2007

SAES, M. S. M. A Racionalidade Econômica da Regulamentação do Mercado Brasileiro de Café. Tese de doutoramento apresentada ao Departamento de Economia da Faculdade de Economia, Administração e Contabilidade da Universidade de São Paulo, em 1995.

SAES, M. S. M. em ZYLBERSZTAJN, D; NEVES, M. F. Economia e gestão dos negócios agroalimentares: indústria de alimentos, indústria de insumos, produção agropecuária, distribuição. São Paulo: Pioneira, 2000.

SANTOS, C.; SCHÜFFNER, C. Ultra avalia compra da Texaco e da Esso. Jornal Valor Econômico, 28/09/2007. Disponível em: $<$ http://infoener.iee.usp.br/infoener/hemeroteca/imagens/106743.htm>. Acessado em: 28/09/2007.

SCARAMUZZO, M.; VIEIRA, A. Biorrefinaria do Ultra vai para MG. Jornal Valor Econômico, 21/09/2007.

SELLTIZ, C.; WRIGHTSMAN, L. S.; COOK, S. W. Métodos de pesquisa nas reações sociais. v. 1. São Paulo: EPU, 1974.

SILVA JUNIOR, W. L. D.; MURAKAMI, S. K. Entrevista com Gerentes de Negócios da Petroluna Distribuidora de Petróleo, 2007.

SILVA, E. C. D; PINTO, M. R. O brilho da bandeira branca: concorrência no mercado de combustíveis no Brasil. XXXII Encontro Nacional de Economia. João Pessoa, 2004.

SIMON, H. Models of Bounded Rationality: Behavioral Economics and Business Organization. Cambridge: MIT Press, 1982. 
SINDICATO DO COMÉRCIO VAREJISTA DE DERIVADOS DE PETRÓLEO DO ESTADO DE SÃO PAULO (SINCOPETRO). Preços de custo de aquisição das companhias distribuidoras. Disponível em: $<$ http://www.sincopetro.org.br/conteudo.asp?xmenu=110>. Acessado em: 29/11/2007.

SINDICATO NACIONAL DAS EMPRESAS DISTRIBUIDORAS DE COMBUSTÍVIS E LUBRIFICANTES (SINDICOM). Bases de Distribuição. Disponível em: $<$ http://www.sindicom.com.br/pub_sind/cgi/cgilua.exe/sys/start.htm?sid=23>. Acessado em: 08/10/2007. (a)

SINDICATO NACIONAL DAS EMPRESAS DISTRIBUIDORAS DE COMBUSTÍVIS E LUBRIFICANTES (SINDICOM). Logística. Disponível em: $<$ http://www.sindicom.com.br/pub_sind/cgi/cgilua.exe/sys/start.htm?sid=72>. Acessado em: 08/10/2007. (b)

SINDICATO NACIONAL DAS EMPRESAS DISTRIBUIDORAS DE COMBUSTÍVIS E LUBRIFICANTES (SINDICOM). Vendas, pelas distribuidoras associadas ao Sindicom e Mercado ANP, dos derivados Combustíveis de Petróleo e Álcool Hidratado- 2000-2008 (m3), 2008. Disponível em: http://www.sindicom.com.br/pub_sind/cgi/cgilua.exe/sys/start.htm?sid=19. Acessado em: 01/10/2008.

SINDICATO NACIONAL DAS EMPRESAS DISTRIBUIDORAS DE COMBUSTÍVIS E LUBRIFICANTES (SINDICOM). Apresentação. Disponível em: $<$ http://www.sindicom.com.br/pub_sind/cgi/cgilua.exe/sys/start.htm?sid=6>. Acessado em: 08/10/2008.

STRAUSS, A. Qualitative research for social scientists. Cambridge: Cambridge University Press, 1987.

STRAUSS, A.; CORBIN, J. Basics of Qualitative Research: Grounded Theory Procedures and Techniques. Thousand Oaks: Sage Publications, 1990.

STRAUSS, A; CORBIN, J. Basics of qualitative research: tecniques and procedures for developing Grounde Theory. $2^{\mathrm{a} e d}$. Thousand Oaks: Sage Publications, 1998

TORQUATO, S. A. Avanços e Entraves na Logística de Exportação do Álcool. 2005. Disponível em: <http://www.iea.sp.gov.br/out/verTexto.php?codTexto=2855>. Acessado em: 08/10/2007.

WAAK, R.S.; NEVES, M.F. Competitividade do Sistema Agroindustrial da cana-deaçúcar. Competitividade no Agribusiness Brasileiro V. 1998

WILLIAMSON, O. E. Calculativeness, Trust, and Economic Organization. The Journal of Law and Economics, v. 36, nº 1, p. 453-486, 1993. 
WILLIAMSON, O. E. Comparative economic organization: the analysis of discrete structural alternatives. Administrative Science Quarterly, n. 36, p. 269-296, June, 1991.

WILLIAMSON, O. E. The Economic Institutions of Capitalism: Firms, Markets, Relational Contracting. New York: The Free Press, 1985.

WILLIAMSON, O. E. The mechanisms of governance. New York: Oxford University Press, 1996.

XAVIER, C. E. O. Comunicação pessoal com pesquisador da Esalq-Log, 2007

XAVIER, C. E. O. Localização de tanques de armazenagem de álcool combustível no Brasil: aplicação de um modelo matemático de otimização. Dissertação apresentada para obtenção do título de Mestre em Ciências. Área de concentração: Economia Aplicada, 2008.

ZYLBERSZTAJN, D. Direito e Economia. Rio de Janeiro: Elsevier, 2005.

ZYLBERSZTAJN, D. Estrutura de governança e coordenação do agribusiness: uma aplicação da nova economia das instituições. Tese submetida ao Departamento de Administração da Faculdade de Economia, Administração e Contabilidade da Universidade de São Paulo para obtenção do título de Livre Docente. São Paulo, 1995. 


\section{APÊNDICE I}

\section{A - COORDENAÇÃO}

\section{A.1 - Coordenação da produção}

\section{Coordenação do processo produtivo}

1.1. Qual a duração média do contrato (Anidro e Hidratado)? Os dois têm a mesma duração?

1.2. Qual o volume negociado via contrato e total (Anidro e Hidratado)?

1.3. Como foi a evolução dessa porcentagem nos últimos anos? Houve aumento de contratação depois da Resolução 7 da ANP? (Novamente, separando hidratado de Anidro)?

1.4.Quem faz contratos? Usinas grandes $\mathrm{X}$ pequenas? Sindicom x Emergentes? Existe adoção mista, ou seja, uma usina que vende uma parte da produção via contrato e uma parte spot (Qual a racionalidade dessa decisão?)? Ou só um dos alcoóis via contrato? Questões como Adulteração e sonegação têm ligação com a disposição a usar mais ou menos contratos?

1.5. Qual a freqüência da retirada (Anidro e Hidratado)?

1.6. Qual a diferença entre contrato de Anidro e o de Hidratado?

1.7. Quais tipos de contratos existem? Há diferença nos contratos fechados com diferentes distribuidoras do Sindicom? Existe diferença entre o contrato usado por usinas em pool e por usinas que comercializam individualmente?

1.8. Existe diferença no volume de adesão negociação via contratos frente ao total quando comparado o momento de Pico com o início e fim da safra?

1.9. Na prática, a adoção de contrato uniformiza as entregas no tempo, diminuindo o efeito de escassez da entressafra? Ou seja, hipoteticamente, se todo álcool fosse comercializado via contratos, a volatilidade do preço deveria diminuir (Numa situação SEM grandes anomalias)?

1.10. O uso de contrato futuro promove tal "linearidade" do escoamento (Numa situação SEM grandes anomalias)?

1.11. Qual a relação Usina-Pool em cada caso: Copersucar, SCA, Crystalsev, Bioagência, CPA Trading. (Existe a SOL?) Por que existe duplicidade SCA x Crystalsev?

1.12. A compra de anidro é orientada pela compra de gasolina A, cujas cotas são definidas pela ANP! Essas cotas têm vigência de quanto tempo? A vigência do contrato de anidro nunca poderá superar a da cota de gasolina A?

1.13. A distribuidora mantém algum tipo de estoque? De gasolina A? C? Etanol? Diesel? 


\section{Coordenação do comportamento de mercado}

2.1. Qual o mercado relevante? O Centro-Sul pode ser considerado como um único mercado, apesar do custo de frete, ou seja, apesar dessa diferença entre as usinas, todas elas competem entre si, ou o custo de frete divide o mercado em praças?

2.2. Existem praças menos competitivas? É possível evidenciar tal fato? Nessas praças o uso de contratos é maior?

2.3. Algum grupo comercial, ou pool, é capaz de influenciar o preço de mercado? Os Pools, juntos, detêm quase 50\% do volume de álcool. Poderia ser esperada alguma atitude oligopolista da oferta, como se costuma dizer da demanda (Sindicom)?

2.4. Qual a forma certa de avaliar a concentração do mercado? Por grupo comercial ou por Pool?

2.5. Existe alguma situação em que o preço acordado no contrato é fixado de maneira diferente do Índice ESALQ?

2.6. A distribuidora consegue repassar $100 \%$ de qualquer aumento? Ela realmente trabalha com um ganho sobre volume (Litragem), ou seja, não é “ad valorem” (\% sobre o valor)?

2.7. Qual a principal estratégia competitiva do setor de Distribuição de combustível (Álcool)? É ganhar "Share”? Como a distribuidora ataca essa questão, comprando no mesmo patamar que a concorrência e investindo na relação com os franqueados?

\section{A.2 - Coordenação do risco}

\section{Risk sharing (alocação de risco)}

3.1.(Hidratado) É correto dizer que a distribuidora, trabalhando “da mão prá boca” e usando Preço Esalq, não assimila risco de mercado (Perda de competitividade frente à gasolina. EX: Uma destilaria com 2 colunas, que só produz hidratado, como fica, nesse caso a destilaria continua tomando todo o risco de mercado para si?

3.2. Qual o período máximo que as usinas se dispõem a garantir oferta? A racionalidade dessa decisão é diferente para Anidro e Hidratado?

3.3. Existe preocupação com eventual quebra contratual? Se uma usina quiser deixar de fornecer durante a vigência do contrato, ele seria protestada judicialmente pela distribuidora? Existe quebra contratual?

3.4.Em última instância, de quem é a responsabilidade se faltar Anidro? A distribuidora será cobrada por isso? Quem está assumindo esse risco (Institucional)? 
3.5. O risco institucional de mudança de alíquotas de impostos causa preocupação às usinas? Isso é levado em conta quando elas tomam suas decisões? Na prática, a distribuidora não se preocupa com isso também, certo?

3.6. Em que momento a usina decide o mix da próxima safra? Isso pode ser alterado no meio do caminho? E o mix da safra subseqüente, é discutido previamente?

3.7. No conjunto, a oferta de álcool pode ser qualificada como elástica. Uma distribuidora nunca poderia contratar todo o Anidro do Centro-Sul da safra subseqüente e tirar seus competidores do negócio de Gasolina C? Nenhuma distribuidora tem medo de escassez de anidro/hidratado devido a uma antecipação de uma concorrente?

\section{Minimizing risk}

4.1. Existe algo no contrato que minimiza o risco total da cadeia?

4.2. Se não existe, que ponto poderia gerar tal resultado? Uso de contrato futuro?

\section{B - MOTIVAÇÃO}

\section{Participação (OBS: ver multiple tasks também)}

5.1. (Hidratado e Anidro) Qual a utilidade desses contratos para cada parte envolvida? Quais os pontos (cesta) que compõem essa utilidade para cada agente? Sendo direto: Por que cada parte tem interesse em fechar esse tipo de contrato?

5.2. O aumento da demanda devido ao flex está influenciando a apreciação da utilidade desse negócio pelas Distribuidoras e Usinas?

5.3. Qual é a motivação das usinas em estabelecer esses contratos, se não existe qualquer diferença no preço que ela vai obter? Esse contrato é usado pela usina para conseguir algum tipo de condição especial de financiamento?

5.4. As usinas, em geral, têm fôlego financeiro para manter estoques, ou isso é um determinante da disposição à venda quando a safra começa?

5.5. Existe limitação de armazenagem pelas usinas, capaz de forçá-las a comercializar devido ao custo de manter o produto estocado? Não estou perguntando sobre o custo financeiro da estocagem!

5.6. Se houver quebra contratual, qual a perda para cada agente?

5.7. Existe alguma relação direta entre a opção por contratos e a capacidade de "especular" no mercado a vista pela Usina?

5.8. Qual utilidade do contrato de 3 anos da BR? Por que a BR é a única que faz contrato de longo prazo? Por que não se faz contratos normalmente mais longos, não seria útil para as partes? Quem não deseja isso? 
5.9. Existe pressão do governo para que se estabeleçam contratos? Isso influencia a existência desses contratos?

5.10. Em última instância, qual a motivação da distribuidora ao contrato?

\section{B.2 - Motivação ao esforço}

\section{Objetivos múltiplos (ligado a 9-portfolio problem)}

6.1.(Igual a 9.1) Como é a comparação de lucratividade-retorno (a rigor: Utilidade?) entre o negócio de distribuição de álcool e gasolina para a distribuidora?

6.2. Como é a comparação de lucratividade (a rigor: Utilidade?) do negócio de Anidro x Hidratado x Açúcar x Energia Elétrica para as Usinas?

6.3. O contrato aborda questões de multiplicidade de objetivos? Estabelece qualquer acordo com base em condições relacionadas a outros objetivos dos agentes? Exemplo de conflito da usina: Açúcar x Álcool, Anidro X Hidratado. Na distribuidora: Hidratado x Gasolina.

6.4. Seria esse o motivo da Usina não querer compromisso mais longo que 1 safra?

\section{Múltiplos produtores}

7.1. O contrato prevê premiação por desempenho ou punição por descumprimento do acordo?

7.2. O contrato é capaz de motivar os agentes a manter atenção (esforço) ao acordo? Dê que forma? Isso leva a possibilidade de discriminação entre agentes comprometidos ou não com o acordo?

\section{B.3 - Motivação ao Investimento}

\section{Hold-up problem (repassar a existência de ativo específico)}

8.1. Qual a dinâmica: O contrato é fechado antes de se fazer algum investimento? Existe esse tal investimento sendo abordado no contrato?

8.2. Existe qualquer outro investimento sendo feito devido a algum outro contrato ou acordo bilateral entre Usinas e Distribuidoras? Existe alguma solicitação (Influence Cost) de uma parte à outra que está, ou não, sendo atendida?

8.3. O governo atua como promotor de investimento no setor? Existem garantias quando o governo é o agente promotor de investimento? Garantias do governo são bem avaliadas?

8.4. Especificidade de ativo físico: base de distribuição. 
8.5. As bases de distribuição carregam qualquer especificidade, ou seja, alguma estrutura “dedicada”? Elas podem ser revertidas para outro combustível? Existe a situação de dependência bilateral entre uma base e uma usina?

8.6. Tanto a base primária como a secundária pode operar a mistura de gasolina A com anidro?

8.7. O que é o centro coletor?

8.8. Especificidade de ativo físico: frota

8.9. A frota tem que sofrer qualquer adaptação para ser convertida para uso de outro combustível?

Ela é “dedicada”? O caminhão tem que ser lavado, isso é caro, esse custo é relevante? A frota tem que sofrer qualquer adaptação para ser convertida para uso de outro combustível? Ela é “dedicada”? O caminhão tem que ser lavado, isso é caro, esse custo é relevante?

8.10. Existe alguma situação tipo “refém” entre usina e distribuidora?

8.11. Especificidade humana: a usina/distribuidora tem que manter algum profissional específico para negociar álcool, como um gerente de contas, que constrói relacionamento específico?

8.12. Especificidade Temporal: Existe algum tipo de priorização quanto ao momento do atendimento? Alguma distribuidora tem atendimento preferencial às outras?

\section{Horizon problem}

9.1. Qual o horizonte de investimento da Usina em geral?

9.2. Qual o horizonte de investimento da distribuidora em geral?

9.3. A usina quer contratos de mais de 1 ano ( 1 safra)? O ciclo de colheita dura 5 a 6 cortes, a usina não preferiria ter contratos que cobrissem esse tempo? (Ver Risk Sharing, Decisão de Mix)

9.4. Caso o contrato motive investimento, ele estaria harmonizando os horizontes dos agentes?

\section{Portfolio problem (ligado a risk sharing e minimizing e participação)}

10.1. Como é a comparação do risco entre os investimentos (atuação) no negócio de distribuição de álcool x gasolina para a distribuidora?

10.2. Como é a comparação do risco entre os investimentos (atuação) no negócio de Anidro x Hidratado x Açúcar x Energia Elétrica para as Usinas?

10.3. Ao passar a operar com álcool, a distribuidora teve qualquer mudança do perfil de risco de seu portfólio de investimentos?

10.4. Existe diferença no mecanismo de governança num caso de portfólio de produto mais restrito? Ex.: Destilaria com 2 torres! 


\section{C - CUSTOS DE TRANSAÇÃO}

\section{Adoção do contrato (entering contract)}

11.1. Existem custos de elaborar e redigir os contratos? Cada renegociação exige alteração, ou usa o mesmo contrato e só revê o preço?

11.2. Existem gastos específicos para se tentar prever contingências? EX: Comprar estudos de mercado.

11.3. Quem redige o contrato? As distribuidoras têm cada qual um modelo? Os agentes têm dificuldade de se entender, ou a linguagem é bem compreendida por ambos os lados? Os profissionais dos Pools de comercialização têm participação da redação do contrato?

11.4. Existe gasto com advogados para adequar o conteúdo do contrato dentro da linguagem jurídica? Esse gasto é único ou deve ser feito anualmente?

\section{Resolução de conflitos}

12.1. O contrato indica previamente a forma de resolução de eventuais conflitos?

\section{Monitoramento}

13.1. Existem gastos para se monitorar os itens do acordo firmado?

13.2. Como a distribuidora tem certeza da "qualidade” (especificação técnica) do produto que está retirando, como porcentagem de água e contaminantes? Existe gasto com laboratório de controle de qualidade? Existe gasto com seguro para eventuais erros?

\section{Custo de influência}

14.1. Existe algum gasto em tentativas de influenciar (ex-ante) a contra-parte? 